University of South Florida

DIGITAL COMMONS

Digital Commons @ University of

@ UNIVERSITY OF SOUTH FLORIDA

South Florida

KIP Articles

KIP Research Publications

January 1994

\title{
Geologic history and hydrogeologic setting of the Edwards-Trinity aquifer system, west-central Texas
}

Rene A. Barker

Peter W. Bush

E.T. Baker

Follow this and additional works at: https://digitalcommons.usf.edu/kip_articles

\section{Recommended Citation}

Barker, Rene A.; Bush, Peter W.; and Baker, E.T., "Geologic history and hydrogeologic setting of the Edwards-Trinity aquifer system, west-central Texas" (1994). KIP Articles. 2169.

https://digitalcommons.usf.edu/kip_articles/2169

This Article is brought to you for free and open access by the KIP Research Publications at Digital Commons @ University of South Florida. It has been accepted for inclusion in KIP Articles by an authorized administrator of Digital Commons @ University of South Florida. For more information, please contact digitalcommons@usf.edu. 


\section{GEOLOGIC HISTORY AND HYDROGEOLOGIC SETTING OF THE EDWARDS-TRINITY AQUIFER SYSTEM, WEST- CENTRAL TEXAS}

By Rene' A. Barker, Peter W. Bush, and E.T. Baker, Jr.

\section{U.S. GEOLOGICAL SURVEY}

Water-Resources Investigations Report 94-4039 


\section{U.S. DEPARTMENT OF THE INTERIOR \\ BRUCE BABBITT, Secretary \\ U.S. GEOLOGICAL SURVEY \\ Gordon P. Eaton, Director}

Any use of trade, product, or firm names is for descriptive purposes only and does not imply endorsement by the U.S. Government.

For additional information write to:

\section{District Chief}

U.S. Geological Survey

8011 Cameron Rd.

Austin, TX 78754-3898
Copies of this report can be purchased from:

U.S. Geological Survey

Earth Science Information Center

Open-File Reports Section

Box 25286, Mail Stop 517

Denver Federal Center

Denver, CO 80225-0046 


\section{CONTENTS}

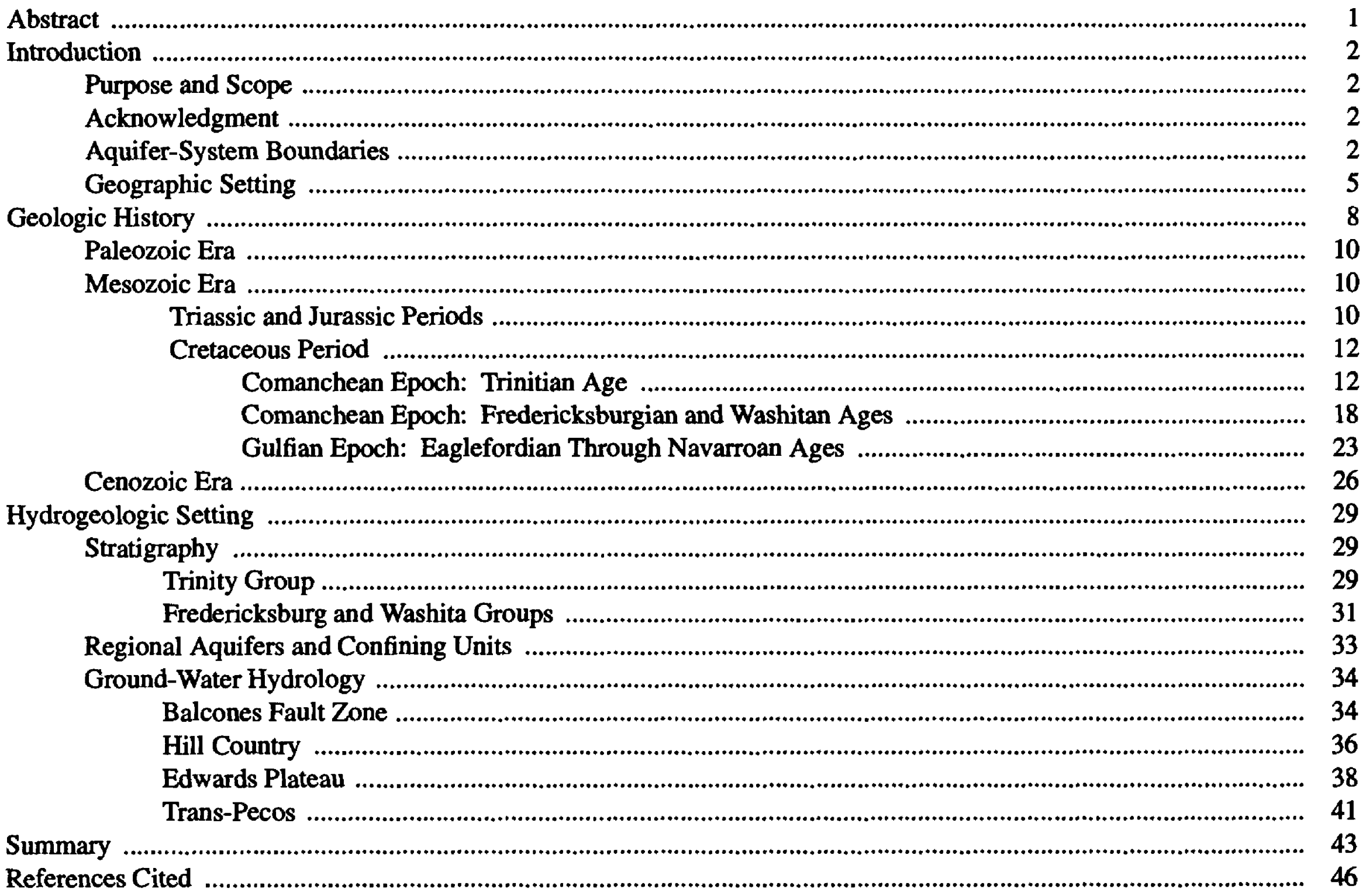

\section{FIGURES}

1-3. Maps showing:

1. Location of the study area of the Edwards-Trinity Regional Aquifer-System Analysis

2. Location of the aquifers and confining units in the Edwards-Trinity aquifer system and of selected adjacent aquifers

3. Location of geographic subareas of the Edwards-Trinity aquifer system and the major springs and streams.

4. Schematic section showing generalized relation between the Edwards-Trinity aquifer system and the pre-Cretaceous rocks and hydrogeologic units that form the base of the system

5. Map showing paleogeographic and structural features in west-central Texas and parts of adjacent States and northern Mexico

6. Map showing lateral distribution of Trinity rock units in west-central Texas

7. Schematic diagrams showing vertical distribution of Trinity rock units in west-central Texas and their relation to geographic subareas..

8. Schematic diagram showing structural controls on the deposition of Fredericksburg and Washita

9. Map showing lateral distribution of Fredericksburg and lower Washita rock units in west-central Texas

10. Schematic diagrams showing vertical distribution of Fredericksburg and lower Washita rock units in west-central Texas and their relation to depositional environments

11. Schematic diagram showing progression of major depositional, tectonic, and diagenetic events affecting the development of the Edwards-Trinity aquifer system 


\section{TABLE}

1. Correlation chart showing the chronostratigraphic, lithostratigraphic, and regional hydrogeologic units in the Edwards-Trinity aquifer system, west-central Texas

2. Approximate maximum thickness of lithostratigraphic units that compose the Edwards-Trinity aquifer system, west-central Texas

CONVERSION FACTORS, VERTICAL DATUM, AND WATER-QUALITY UNIT

\begin{tabular}{|c|c|c|}
\hline Multiply & By & To obtain \\
\hline acre-foot (acre-ft) & 0.001233 & cubic hectometer \\
\hline acre-foot per year (acre-ft/yr) & 0.001233 & cubic hectometer per year \\
\hline cubic foot per second $\left(\mathrm{ft}^{3} / \mathrm{s}\right)$ & 0.02832 & cubic meter per second \\
\hline foot (ft) & 0.3048 & meter \\
\hline foot per mile (ft/mi) & 0.1894 & meter per kilometer \\
\hline foot squared per day $\left(\mathrm{ft}^{2} / \mathrm{d}\right)$ & 0.09290 & meter squared per day \\
\hline gallon per minute (gal/min) & 0.06308 & liter per second \\
\hline inch (in.) & 25.4 & millimeter \\
\hline inch per year (in/yr) & 25.4 & millimeter per year \\
\hline mile $(\mathrm{mi})$ & 1.609 & kilometer \\
\hline mile squared $\left(\mathrm{mi}^{2}\right)$ & 2.590 & kilometer squared \\
\hline
\end{tabular}

Sea level: In this report, "sea level" refers to the National Geodetic Vertical Datum of 1929-a geodetic datum derived from a general adjustment of the first-order level nets of the United States and Canada, formerly called Sea Level Datum of 1929.

\section{Water-quality unit:}

$\mathrm{mg} / \mathrm{L}$, milligram per liter 


\title{
Geologic History and Hydrogeologic Setting of the Edwards-Trinity Aquifer System, West- Central Texas
}

\author{
By Rene' A. Barker, Peter W. Bush, and E.T. Baker, Jr.
}

\section{Abstract}

The Edwards-Trinity aquifer system underlies about 42,000 square miles of west-central Texas. Nearly flat-lying, mostly Comanche (Lower Cretaceous) strata of the aquifer system thin northwestward atop massive pre-Cretaceous rocks that are comparatively impermeable and structurally complex. From predominately terrigenous clastic sediments in the east and fluvialdeltaic (terrestrial) deposits in the west, the rocks of early Trinitian age grade upward into supratidal evaporitic and dolomitic strata, intertidal limestone and dolostone, and shallow-marine, openshelf, and reefal strata of late Trinitian, Fredericksburgian, and Washitan age. A thick, downfaulted remnant of mostly open-marine strata of Eaglefordian through Navarroan age composes a small, southeastern part of the aquifer system.

The Trinity Group was deposited atop a rolling peneplain of pre-Cretaceous rocks during three predominately transgressive cycles of sedimentation that encroached upon the Llano uplift. The Fredericksburg and Washita Groups were deposited above the Trinity Group mostly in the lee of the Stuart City reef trend, a shelf margin ridge that sheltered depositional environments in the study area. The Washita Group subsequently was covered with thick, mostly fine-grained Gulf strata.

During late Oligocene through early Miocene time, large-scale normal faulting formed the Balcones fault zone, where the Cretaceous strata were downfaulted, intensively fractured, and differentially rotated within a series of northeasttrending fault blocks. In addition to fracturing the rocks in the fault zone and extending the depth of freshwater diagenesis, the faulting vertically displaced the terrain, which steepened hydraulic gradients and maintained relatively high flow velocities near the surface. A shallow regime of dynamic ground-water flow evolved that promoted dissolution and enhanced the transmissivity of the Edwards Group in the Balcones fault zone. Cementation, recrystallization, and mineral replacement - caused by deeper, comparatively sluggish ground-water circulation-combined to diminish the transmissivity of the underlying Trinity Group, as well as most Cretaceous strata in the Hill Country, Edwards-Plateau, and Trans-Pecos.

The Trinity, Fredericksburg, and Washita strata compose a regional aquifer system of three aquifers, whose water-transmitting characteristics generally are continuous in the lateral direction, and two hydraulically tight confining units. The aquifers are the Edwards aquifer in the Balcones fault zone, the Trinity aquifer in the Balcones fault zone and Hill Country, and the Edwards-Trinity aquifer in the Edwards Plateau and Trans-Pecos. The Navarro-Del Rio confining unit overlies the subcrop of the Edwards aquifer, and the Hammett confining unit lies within the updip, basal part of the Trinity aquifer and a small southeastern fringe of the Edwards-Trinity aquifer. The confining units are mostly calcareous mudstone, siltstone, and shale of low-energy terrigenous and openshelf marine depositional environments. The aquifers mainly result from fractures, joint cavities, and porosity caused by the dissolution of evaporites and unstable carbonate constituents. 
Because the diagenetic effects of cementation, recrystallization, and mineral replacement diminish the hydraulic conductivity of most rocks composing the Trinity and Edwards-Trinity aquifers, transmissivity values average less than 10,000 feet squared per day over more than 90 percent of the study area. However, the effects of tectonic fractures and dissolution in the Balcones fault zone cause transmissivity values to average about 750,000 feet squared per day in the Edwards aquifer, which occupies less than 10 percent of the study area.

\section{INTRODUCTION}

The Edwards-Trinity aquifer system, underlying about 42,000 $\mathrm{mi}^{2}$ of west-central Texas, was studied as part of the U.S. Geological Survey's Regional AquiferSystem Analysis (RASA) program. The Geological Survey began the RASA program in 1978 to define the hydrogeology of large aquifer systems in the United States. The Edwards-Trinity RASA is one of 28 RASA projects nationwide that were identified for study under the program (Weeks and Sun, 1987, fig. 1).

Available data on the hydrogeology of westcentral Texas generally cover smaller areas than the regional scale of this RASA project. Therefore, the contents of this report were synthesized primarily from the published work of investigators in colleges and universities, in agencies of local and Federal governments, and in industry. Chief contributors are the U.S. Geological Survey, the Bureau of Economic Geology of the University of Texas at Austin, the Texas Water Development Board, and the Texas Natural Resource Conservation Commission. Publications of the American Association of Petroleum Geologists and the Geological Society of America, and some unpublished dissertations and theses from the University of Texas (Austin and Arlington) also were useful.

\section{Purpose and Scope}

This report summarizes the geologic history and hydrogeologic setting of the rocks that compose the Edwards-Trinity aquifer system. Pertinent depositional, tectonic, and diagenetic events are reviewed in the section "Geologic History." The "Hydrogeologic
Setting" section relates the regional aquifers and confining units to their chronostratigraphic and lithostratigraphic counterparts and summarizes ground-water conditions in the study area.

\section{Acknowledgment}

Much of the geologic information provided in this report for the western part of the study area was summarized from unpublished maps and notes volunteered by Dr. C.I. "Ike" Smith, Chairman, Department of Geology at the University of Texas at Arlington. The authors are greatly indebted to Dr. Smith for his generous contributions.

\section{Aquifer-System Boundaries}

The study area of the Edwards-Trinity RASA comprises the Edwards-Trinity aquifer system plus contiguous hydraulically connected units (fig. 1). The contiguous hydraulically connected units are between the boundary of the Edwards-Trinity aquifer system and the natural or assumed boundaries of the regional ground-water-flow system, where the two are not coincident.

The Edwards-Trinity aquifer system contains three major aquifers and two major confining units (fig. 2). From east to west, the aquifers are the Edwards aquifer, Trinity aquifer, and Edwards-Trinity aquifer. The aquifers are laterally adjacent except in the southeastern part of the system, where the downdip part of the Trinity aquifer is overlain by the Edwards aquifer. The Navarro-Del Rio confining unit overlies the subcrop of the Edwards aquifer, and the Hammett confining unit lies within the updip, basal part of the Trinity aquifer and a small southeastern fringe of the EdwardsTrinity aquifer.

The boundary of the Edwards-Trinity aquifer system (fig. 2) is the limit of conterminous Cretaceous strata that are the principal source of ground water. This boundary has been defined on the basis of geologic and hydrologic considerations.

Geologic boundaries delineate the northern and western limits of the aquifer system from west-central Travis County in the east to eastern Brewster County in the west. The northern boundary between west-central Travis County and the northwestern corner of Ector County is the approximate updip limit of Cretaceous 


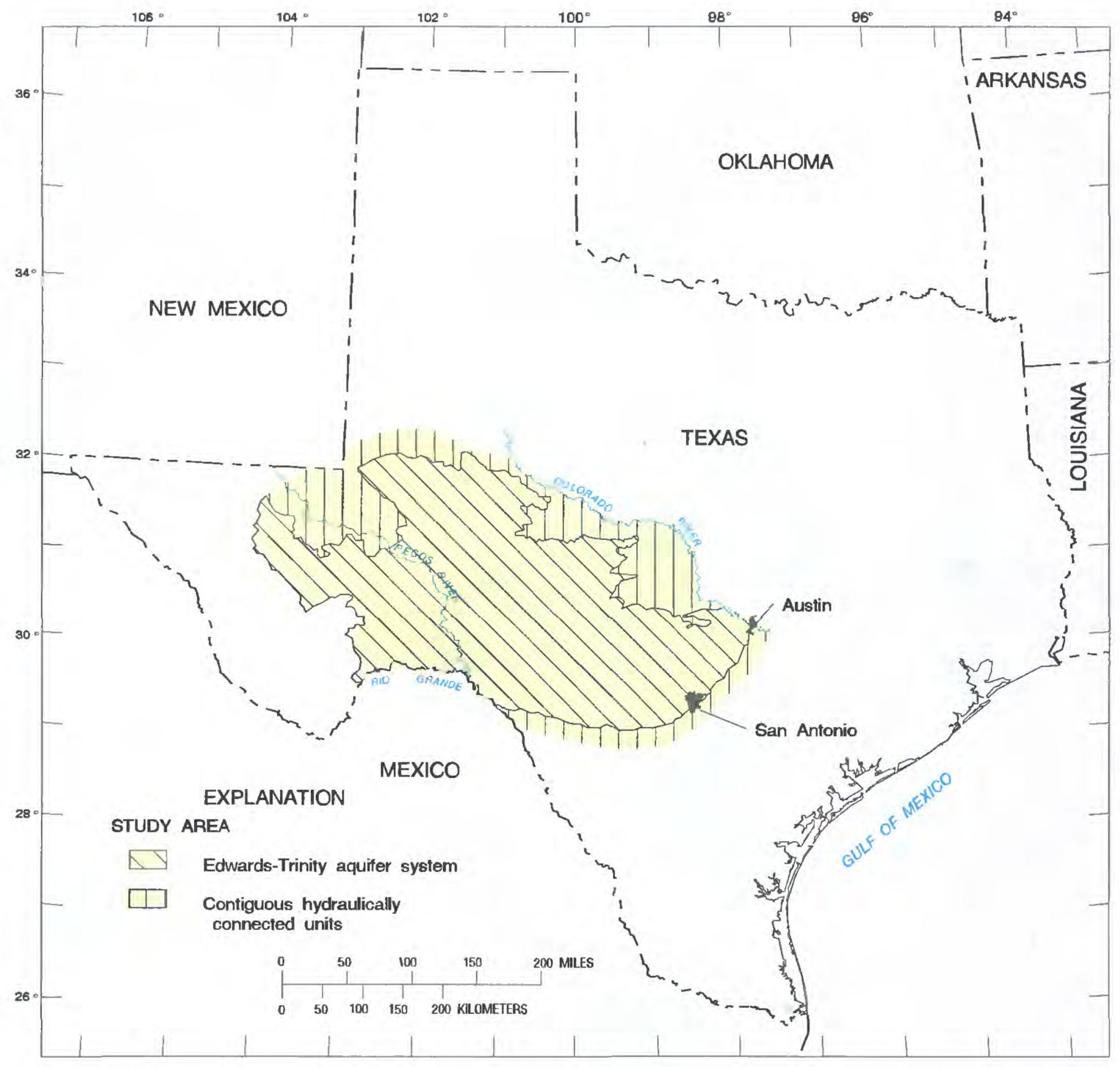

Figure 1. Location of the study area of the Edwards-Trinity Regional Aquifer-System Analysis. 


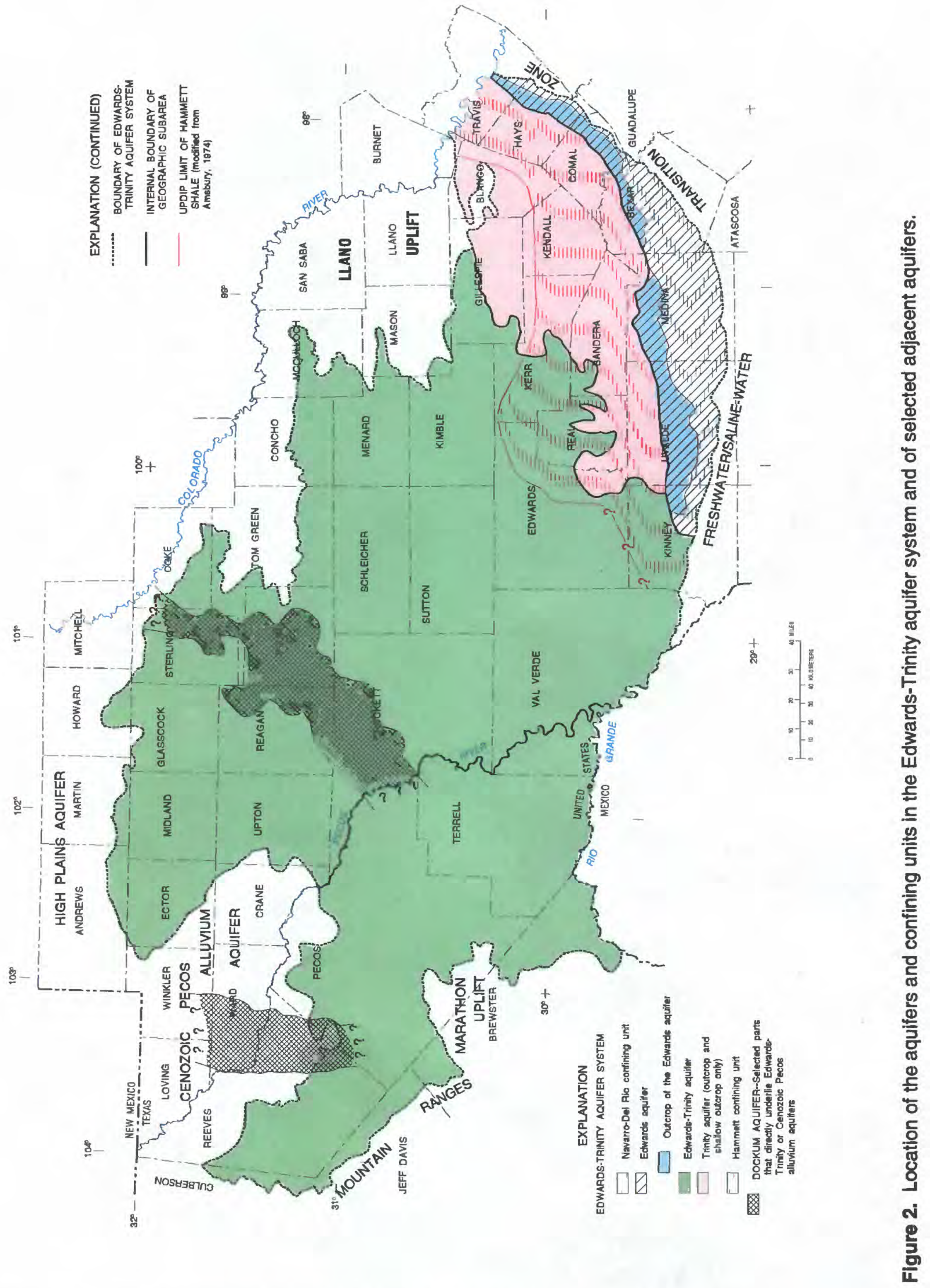


rocks (University of Texas, Bureau of Economic Geology, 1974b; 1975; 1976a; 1981a; Ashworth and Flores, 1991, fig. 1). In some areas, the boundary is indicated topographically by a low escarpment facing away from the aquifer system. The boundary is drawn arbitrarily between central Howard County and northwestern Ector County because sandy intervals of the High Plains aquifer (Weeks and others, 1988) are virtually indistinguishable from the sand unit that comprises most of the Edwards-Trinity aquifer system in that area (Mount and others, 1967, p. 45). Between northwestern Ector County and Culberson County, the boundary of the Edwards-Trinity aquifer system is where Cretaceous rocks abut the Cenozoic Pecos alluvium (University of Texas, Bureau of Economic Geology, 1976b; Rees and Buckner, 1980, fig. 2). The western boundary between Culberson County and the Rio Grande in Brewster County is defined by the eastern flanks of several mountain ranges where the Cretaceous rocks pinch out, are structurally detached, or are virtually impermeable (Rees and Buckner, 1980, fig. 2).

Hydrologic boundaries were used to delineate the southern and eastern limits of the aquifer system between eastern Brewster County and west-central Travis County. Because hydraulic-head data indicate that the Rio Grande is a regional ground-water drain (E.L. Kuniansky, U.S. Geological Survey, oral commun., 1987), the southern extent of the aquifer system between eastern Brewster County and southeastern Val Verde County coincides with the Rio Grande. Between the Rio Grande in southeastern Val Verde County and the Colorado River in central Travis County, the aquifer system is bounded by a well-defined, freshwater/ saline-water transition zone (fig. 2) that minimizes the downdip flow of freshwater from the Edwards aquifer. The aquifer system boundary coincides here with the updip edge of the transition zone, defined by the line of 1,000-mg/L (milligrams per liter) dissolved solids (Maclay and others, 1980, fig. 7). A freshwater/salinewater transition zone also is in the Trinity aquifer beneath the Edwards aquifer. Dissolved-solids data from the Trinity aquifer are too sparse to define lines of equal dissolved solids. However, limited data indicate that the transition zone in the Trinity aquifer approximately coincides, in plane view, with the transition zone in the Edwards aquifer (Brune and Duffin, 1983, fig. 12; Duffin, 1974, fig. 18).

The Colorado River forms the northeastern boundary of the aquifer system through west-central Travis County. Although Cretaceous rocks extend north beneath the Colorado River, the river is a regional discharge boundary except near the freshwater/salinewater transition zone, where the Edwards aquifer is confined hundreds of feet below land surface.

The study area (fig. 1) was extended beyond the boundary of the Edwards-Trinity aquifer system to account for the hydraulic connection with contiguous rock units around the southeastern, northeastern, and northwestern edges of the system (fig. 2). The southeastern limit of the study area was drawn arbitrarily to coincide with the estimated location of the 10,000 $\mathrm{mg} / \mathrm{L}$ line of equal dissolved solids, based on data from Maclay and others (1980, p. 13). The study area is bounded on the northeast by the Colorado River, a regional discharge boundary (Kuniansky, 1990) for the aquifers in the contiguous pre-Cretaceous rocks that underlie the river (Mount and others, 1967, pl. 4). The northwestern limit of the study area overlaps the Cenozoic Pecos alluvium aquifer (Ashworth, 1990, fig. 5) and the southernmost part of the High Plains aquifer (Weeks and others, 1988, fig. 1).

Western and central parts of the Edwards-Trinity aquifer system locally are overlain directly by the Del Rio Clay or Buda Limestone. Together, these relatively impermeable units comprise the lower 10 to 20 percent of the Navarro-Del Rio confining unit (fig. 2), which confines downdip parts of the Edwards aquifer in the southeastern part of the study area (fig. 3 ). The base of the Edwards-Trinity aquifer system is formed of Paleozoic and Triassic rocks that are mostly impermeable (Barker and Ardis, 1992). Where adjacent Paleozoic and Triassic rocks are permeable, they form "contiguous hydraulically connected units" (fig. 1).

\section{Geographic Setting}

The extent of the Edwards-Trinity aquifer system was divided into four geographic subareas (fig. 3) based on distinct physiographic, climatic, and geologic characteristics. The subareas, from largest to smallest, are the Edwards Plateau, the Trans-Pecos, the Hill Country, and the Balcones fault zone south of the Colorado River (hereafter referred to as the Balcones fault zone). By definition, the Edwards-Trinity aquifer is coincident with the Edwards Plateau and Trans-Pecos. The Trinity aquifer is the principal aquifer in the Hill Country, and the Edwards aquifer is the principal aquifer in the Balcones fault zone. 


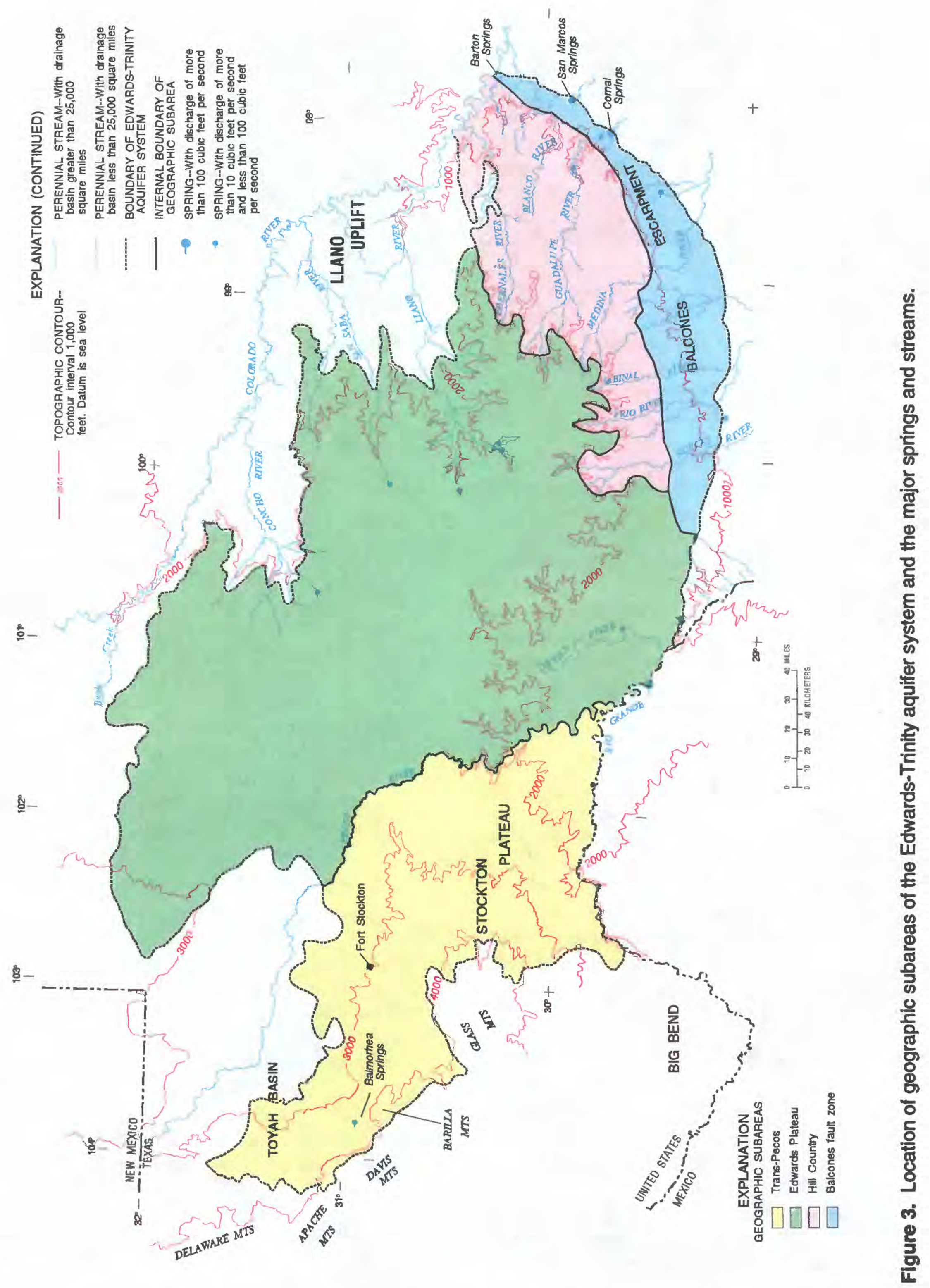


The Edwards Plateau, which covers about $23,750 \mathrm{mi}^{2}$, is a resistant carbonate upland of nearly flat-lying limestone and dolostone, which typically are veneered with loose, thin soils. Caprock mesas, broad alluvial fans, and dry arroyos are the most prominent features on the near-featureless plain. The topographic contours in figure 3 indicate a gradual northwest to southeast slope of land-surface altitude from about 3,000 to about $1,000 \mathrm{ft}$ above sea level.

In contrast to interior parts of the Edwards Plateau, the eastern and southern margins of the Plateau are topographically rugged. High-velocity headwaters have cut narrow, steep-walled canyons into the carbonate terrain around the eastern and southern margin of the plateau. Watercourses that are intermittent in the higher elevations of the Edwards Plateau evolve downstream into perennial streams, as their channels intersect the water table and gain base flow (Kuniansky, 1989).

Most of the carbonate strata in the eastern part of the Edwards Plateau belong to the Edwards Group (Rose, 1972). The Edwards Group and its western equivalents, the Fredericksburg Group and lower part of the Washita Group, are hydraulically connected to terrigenous clastic and carbonate sediments of the underlying Trinity Group. The name "EdwardsTrinity" aquifer thus was adopted for all the permeable Cretaceous rocks on the Edwards Plateau.

The Trans-Pecos covers approximately 9,750 $\mathrm{mi}^{2}$ west of the Pecos River (fig. 3). Southeast of Fort Stockton, in the Stockton Plateau (Fenneman, 1931, p. 47), the Trans-Pecos terrain is an extension of the Edwards Plateau. North and west of Fort Stockton, the Trans-Pecos occupies much of what Fenneman (1931, p. 48) called the Toyah basin, which is the southernmost part of a long, trough-like alluvial valley of the Pecos River. The Toyah basin is topographically flatter than the Stockton Plateau. The Toyah basin is covered with alluvium ranging in thickness from a few feet near the northern edge of the Stockton Plateau to more than $1,000 \mathrm{ft}$ beneath the Pecos River valley. Thus, the Edwards-Trinity aquifer in the Trans-Pecos is exposed or nearly so in the southern part of the subarea and is partly buried under alluvial sediments of varying thickness in the northern part.

Land-surface altitudes in the Trans-Pecos decrease from greater than $4,000 \mathrm{ft}$ in the foothills of mountains that bound the aquifer system on the west to about $1,100 \mathrm{ft}$ near the confluence of the Pecos River and Rio Grande (fig. 3). The Pecos River and Rio
Grande are the only perennial streams in the TransPecos. Between the mountain front and the Pecos River, the land surface is characterized by intermittently flowing stream channels. From well-defined headwater valleys in the western foothills, the intermittent streams drop onto gently inclined lowlands. The stream channels broaden into shallow arroyos as they leave the foothills and enter the alluvial-filled Toyah basin, and nearly disappear as they approach the Pecos River (Armstrong and McMillion, 1961, p. 13-14). Valleys in the Stockton Plateau generally are most clearly defined where they cut through dense carbonate rock. The Pecos River and Rio Grande flow through deep, steep-walled canyons of nearly flat-lying limestone along the eastern and southern boundaries of the Stockton Plateau.

The streams that originate along the southeastern margin of the Edwards Plateau and their downstream tributaries largely are responsible for the high topographic relief of the Hill Country (fig. 3), which covers approximately $5,500 \mathrm{mi}^{2}$. Headward erosion by southeast-flowing streams has stripped all but a few thin remnants of the Edwards Group and its equivalents from the Hill Country, exposing the Trinity Group at land surface; thus, the name "Trinity" was given to the principal aquifer in the Hill Country. The Trinity aquifer in the Hill Country is an extension of the lower part of the Edwards-Trinity aquifer of the Edwards Plateau, with the Edwards Group and its equivalents mostly removed. The boundary between the Edwards Plateau and the Hill Country was delineated from the outcrop configuration of the Trinity rocks (University of Texas, Bureau of Economic Geology, 1977; 1981a; 1983).

The major streams descend steep gradients as they flow through the Hill Country. Many upgradient reaches are contained within deep, narrow canyons characterized by nearly vertical walls. Although most of these canyons widen downstream into broad, flatbottomed valleys, they typically retain their nearly vertical walls. Attributing the widening of the steepwalled canyons to a condition known as "spring sapping," Fenneman (1931, p. 53) stated that the effect of spring discharge in the area was "*** to sap the strong rocks of the canyon walls which thereupon retreat and separate."

The Balcones fault zone, to the south and east of the Hill Country, covers about $3,000 \mathrm{mi}^{2}$ (fig. 3). The relatively gentle southeastward dip of the rocks that compose the Edwards-Trinity aquifer system in the Edwards Plateau and Hill Country is interrupted in the 
Balcones fault zone by an en echelon network of mostly down-to-the-southeast, high-angle normal faults that strike generally southwest to northeast (Maclay and Small, 1986, p. 5). Broken and downfaulted by these faults, the Cretaceous rocks exhibit a steeper southeastward dip in the Balcones fault zone.

The Balcones faults are the principal structural features of the study area, and they greatly influence ground-water flow. The Edwards Group in this area contains the most transmissive rocks in the study area, those composing the Edwards aquifer of the Balcones fault zone. The Trinity Group, which comprises the Trinity aquifer, is deeply buried and relatively impermeable in the Balcones fault zone.

The boundary between the Hill Country and the Balcones fault zone (fig. 3) was determined by linking the updip edge of major faults that juxtapose the Trinity Group on the west against the Edwards Group (or stratigraphic equivalent) on the east. This delineation was based on fault locations provided by the University of Texas, Bureau of Economic Geology (1974a; 1977; 1983), and was substantiated by water-level records (Kuniansky, 1990) and data on the base of the Edwards Group (G.E. Groschen, U.S. Geological Survey, written commun., 1988).

The boundary between the Edwards Plateau and the Balcones fault zone (fig. 3) was determined from well-log and transmissivity data. The data were used to separate the area where the Edwards-Trinity aquifer is the principal aquifer from the area where the Edwards aquifer is the principal aquifer.

The topography of the Balcones fault zone smooths gulfward in a southeastward direction from the Balcones escarpment (fig. 3), a major physiographic divide that locally separates the Great Plains from the Gulf Coastal Plain. The Balcones escarpment approximately coincides with the $1,000-\mathrm{ft}$ topographic contour. Although the Edwards aquifer crops out in the updip part of the Balcones fault zone, the downfaulted strata and steepening structural dip cause the aquifer to be progressively more deeply buried and confined south of the outcrop area (fig. 4).

The broad stream valleys in downgradient parts of the Hill Country narrow where the streams enter the Balcones fault zone and flow atop the relatively permeable Edwards Group (Wermund and Woodruff, 1977, p. 342). The streambeds lose appreciable quantities of water to the Edwards aquifer as they traverse the faulted outcrop area of the Edwards Group. Hydraulic heads in confined parts of the Edwards aquifer are above land surface near the freshwater/saline-water transition zone, resulting in several large springs. Comal and San Marcos Springs (fig. 3) discharge at rates averaging more than $100 \mathrm{ft}^{3} / \mathrm{s}$.

Mean annual (1951-80) precipitation averages about $20 \mathrm{in} / \mathrm{yr}$ over the Edwards-Trinity aquifer system (Riggio and others, 1987, fig. 11). Most precipitation occurs as moisture-laden air from the Gulf of Mexico moves inland and cools. The distribution of perennial streams (fig. 3) attests that considerably less precipitation falls on the western part of the aquifer system than on the eastern part. An increasing distance from the Gulf of Mexico (the principal source of moisture) causes a general westward decrease in the amount of precipitation (Carr, 1967, p. 2). The steepening terrain northwest of the Balcones escarpment superimposes an orographic effect on precipitation over the Hill Country. Mean annual (1951-80) precipitation is about 28 in/yr over the Balcones fault zone, about $30 \mathrm{in} / \mathrm{yr}$ over the Hill Country, about 19 in/yr over the Edwards Plateau, and about 13 in/yr over the Trans-Pecos (Riggio and others, 1987).

May and September generally are the months of greatest precipitation in the Balcones fault zone, Hill Country, and Edwards Plateau. In the Trans-Pecos, precipitation mostly occurs during convective showers and thunderstorms in July, August, and September (Carr, 1967, p. 14; Linsley and others, 1975, p. 61).

\section{GEOLOGIC HISTORY}

The depositional, tectonic, and diagenetic characteristics of the rocks of the Edwards-Trinity aquifer system are different from those of the underlying, comparatively impermeable pre-Cretaceous rocks. Relatively thin, nearly flat-lying Cretaceous strata of the aquifer system typically dip southeastward atop generally massive Paleozoic and Triassic units that generally dip westward (fig. 4). The unconformity between the Cretaceous rocks of the aquifer system and the preCretaceous complex (Barker and Ardis, 1992) marks a major change in the geologic history of the study area. This hiatus spans a transition from the deposition of terrestrial red beds during Late Triassic time to the deposition of terrigenous clastic and shallow-marine carbonate sediments during Early Cretaceous time, transcending about 60 million years of crustal warping and erosion during the Jurassic Period. This section summarizes the geologic history of the pre-Cretaceous rocks upon which the Cretaceous seas encroached and 


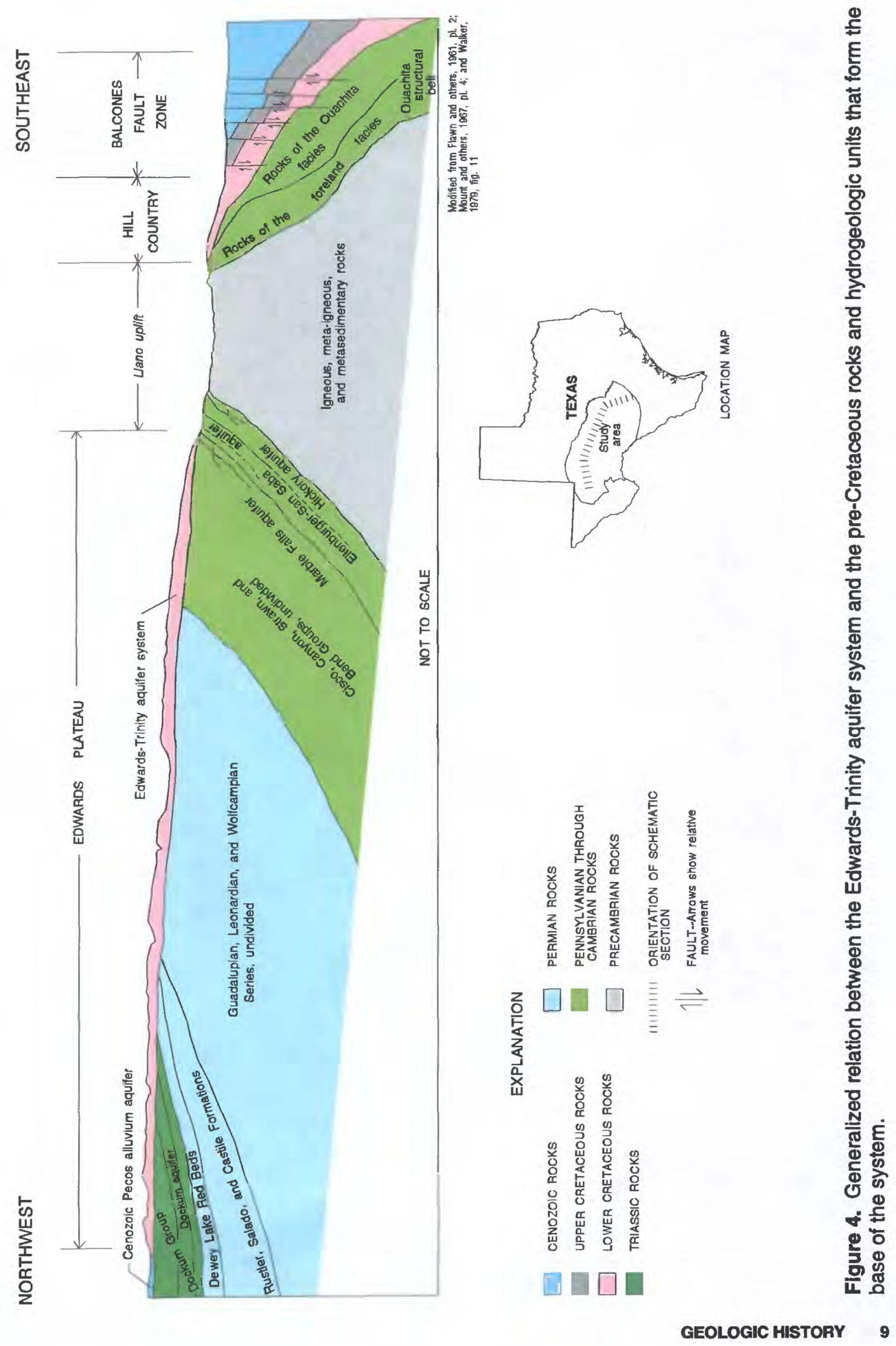


reconstructs the depositional, tectonic, and diagenetic events between the beginning of Cretaceous time and the present day that appear to most affect conditions within the Edwards-Trinity aquifer system.

\section{Paleozoic Era}

The Paleozoic history of west-central Texas was dominated by: (1) the Ouachita geosyncline, an elongated depositional trough that bordered the ancestral North American continent; (2) land masses south and east of the geosyncline; and (3) shallow inland seas across a stable continental foreland, north and west of the geosyncline. Presently, the Ouachita geosyncline is represented by the mostly buried Ouachita structural belt (fig. 5). From southeastern Oklahoma, the Ouachita geosyncline curved around the southeastern and southern margins of the Llano and Devils River uplifts, respectively, to the Marathon and Solitario uplifts of southwestern Texas (Flawn and others, 1961). The Llano and Devils River uplifts were resistant promontories of Precambrian crystalline rock on the southeastern perimeter of ancestral North America. Until Late Permian time, deposition in the broad foreland area was mainly of an organic or chemical nature and was only partly clastic, while clastic deposition prevailed in the geosyncline (Sellards, 1935, p. 18). Intermittent tectonic pulses maintained prominent land areas near the southern and eastern margins of the geosyncline, which supplied the subsiding trough with sediment throughout early and middle Paleozoic time.

Following about 400 million years of mainly uplift and erosion during the late Precambrian and through Early Cambrian time (Flawn, 1956, p. 68-71), about 5,000 ft of Ordovician, Silurian, Devonian, and Mississippian strata were deposited upon an unevenly eroded surface of Precambrian igneous and metamorphic rocks. Depositional rates that increased during the Pennsylvanian Period continued through most of the Permian Period, when more than $5,000 \mathrm{ft}$ of marine sandstone, limestone, and shale were deposited in the foreland area of west-central Texas. The bordering geosyncline continued to subside under the weight of coarse clastic sediment and attained depths of more than 20,000 ft (Sellards, 1933, p. 134). The Ouachita geosyncline was finally overwhelmed by a tectonic upheaval that profoundly affected the geologic history of the study area.
During the Ouachita orogeny, which climaxed between Late Pennsylvanian and Early Permian time, the geosynclinal deposits were uplifted, thrust faulted, and intensively folded into a late Paleozoic mountain range. From the southeastern part of the United States, the ancestral Ouachita Mountains extended through the present Ouachita Mountains of Arkansas and Oklahoma to the Marathon and Solitario uplifts of Texas (fig. 5). The Llano and Devils River uplifts responded as resistant buttresses against which the Ouachita facies were thrust from the south, shearing and folding intervening rocks of the foreland. A complex foreland structure resulted (Webster, 1980), creating petroleum traps that are recognized as some of the most productive oil and gas reservoirs in the world. Interior segments of the Ouachita structure underwent varying degrees of metamorphism-producing slate, phyllite, and metaquartzite- as blocks of early Paleozoic rocks were thrust northward across younger strata.

During the waning stages of the Ouachita orogeny, the Permian Basin (fig. 5) developed in west Texas beneath a broad, shallow sea. The sea became increasingly saline as the basin became more isolated from the open ocean about the middle of Late Permian time, a time of intense aridity and restricted water circulation (King, 1942, p. 711-763). Detrital influx to the basin ceased and the predominant sediments became gypsum, anhydrite, halite, and potash. Following differential uplift and erosion, fresher-water conditions returned. As the connection with the open ocean improved near the end of the Permian Period, the super-saline water became fresher, and fine-grained clastic sediments washed in from surrounding high ground, covering the evaporitic strata with a thin redbed unit. The Permian sea withdrew as the region was again uplifted at the close of the Paleozoic Era.

\section{Mesozoic Era}

\section{Triassic and Jurassic Periods}

The retreat of the Permian sea was followed by a long interval of nondeposition, crustal warping, and erosion during Early and Middle Triassic time. While uplift continued in the Llano area and erosion planed down the central basin platform (fig. 5), a closed continental basin formed in west Texas. This basin was partly filled during Late Triassic time with easily erodible Paleozoic sediments that were redeposited as red 


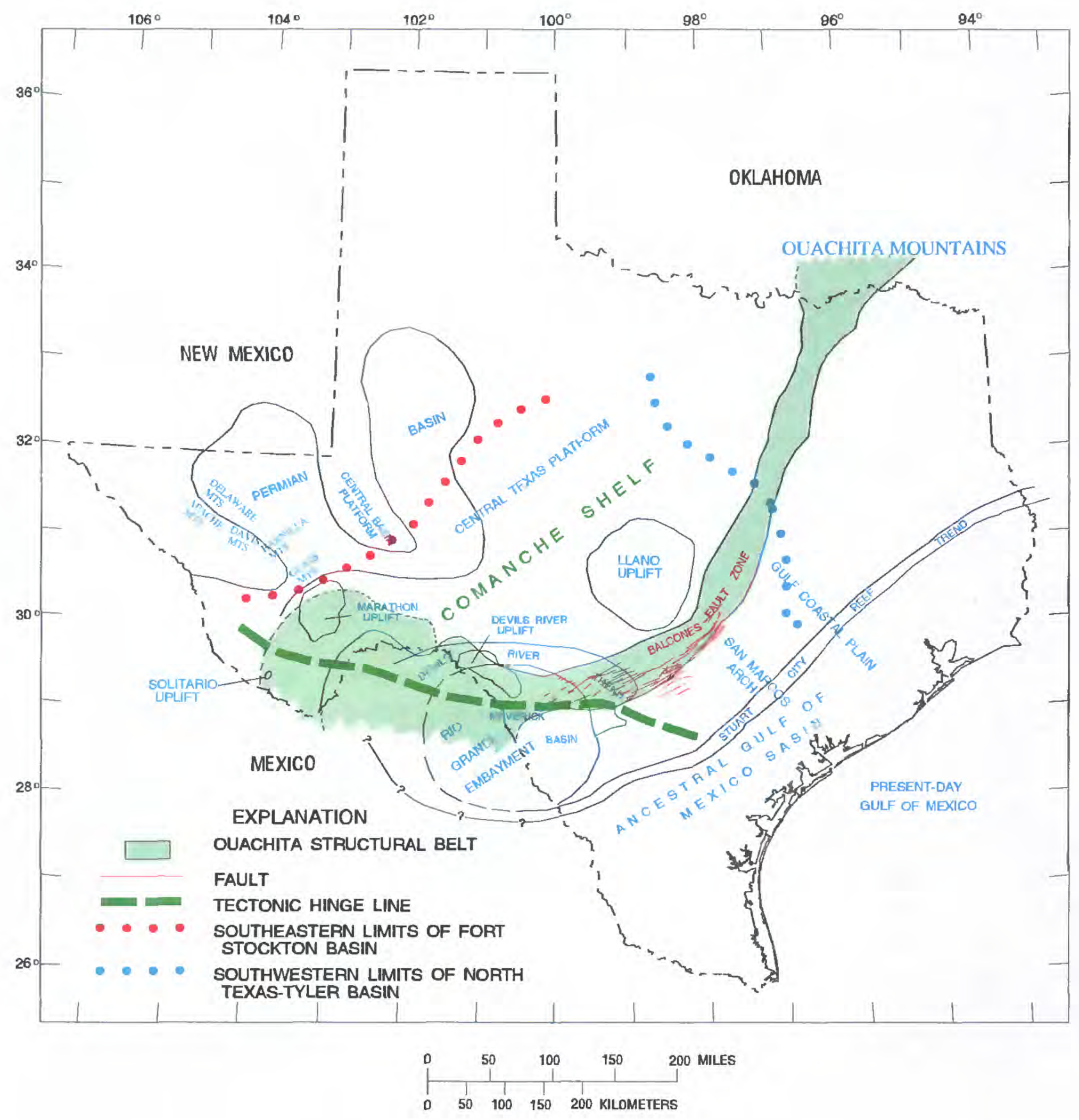

Figure 5. Paleogeographic and structural features in west-central Texas and parts of adjacent States and northern Mexico. 
beds of the Dockum Group under fluvial, deltaic, and lacustrine conditions (McGowen and others, 1979).

Most of west-central Texas was above sea level during the Jurassic Period. During this time, the study area was tilted toward the southeast and eroded to a rolling peneplain characterized by broad river valleys and low ridges of resistant rocks (Hill, 1901). The ancestral Ouachita Mountains mostly were removed by erosion through central Texas, and the remnants sank as the Gulf of Mexico opened (Flawn, 1964, p. 271-274). The land surface tilted southeastward, causing a reversal in the direction of surface drainage. The reversal in drainage, which may have begun during Permian time, was completed by the end of the Jurassic Period so that the earlier pattern of northwestward drainage toward inland seas was superseded by southeastward drainage into a westward-advancing Cretaceous sea (Sellards, 1933, p. 24).

\section{Cretaceous Period}

Rifting and subsidence in the ancestral Gulf of Mexico basin (fig. 5) continued into the Cretaceous Period (Wood and Walper, 1974). A broad continental shelf formed around the rim of the basin, bridging the Yucatan Peninsula and the southeastern part of the United States with the Bahamas (Bebout and Loucks, 1974 , p. 2). The Comanche and Gulf strata of the Edwards-Trinity aquifer system (table 1) formed atop the landward margin of this shelf under predominately shallow-marine conditions of relatively low wave and current energy. The Llano uplift was a dominant structural element through late Trinitian time. During Trinitian time, islands of Precambrian metamorphic and igneous rocks and Paleozoic sedimentary rocks stood high on the uplift and shed clastic debris into nearby fluvial and terrigenous environments (Stricklin and others, 1971, p. 7). By Fredericksburgian time, the Llano uplift was a negligible contributor of sediment; however, a southeastward extension of the Llano uplift, the San Marcos arch (Adkins, 1933, p. 266), continued as a structural ridge between the north Texas-Tyler basin on the northeast and the Rio Grande Embayment on the southwest.

\section{Comanchean Epoch: Trinitlan Age}

Subsidence in the ancestral Gulf of Mexico basin (fig. 5), coupled with an overall rise in sea level, caused the Early Cretaceous sea to advance slowly westward upon the peneplained surface of folded and faulted preCretaceous rocks (Hill, 1901). The Trinity rock record indicates a cyclic, but persistent pattern of transgression; the regressive phases of deposition were relatively short lived and left comparatively little sediment. The regressions may have been triggered by decreasing rates of subsidence, an overall lowering of sea level, increases in the supply of clastic sediment from rising inland source areas, or some combination of these conditions (McFarlan, 1977, p. 10). While terrestrial deposition prevailed on alluvial plains landward of the advancing shoreline, terrigenous and restricted shallow-marine environments dominated the gently inclined upper shelf, over which warm, generally clear seawater circulated. Contacts between the resulting lithofacies are diachronous (time-transgressive) toward the Llano uplift (fig. 5), reflecting the effects of shallower water and shoreline advancement toward the northwest.

The lateral and vertical distributions of the rock units that compose the Trinity Group (table 1) are shown in figures 6 and 7, respectively. The gradational nature of the Trinity rock units is indicated on the southern flank of the Llano uplift (fig. 7a), where basal terrestrial sediments were overlapped by marine deposits as the Early Cretaceous sea encroached upon the feature (Amsbury, 1974).

The Trinity rock units were deposited on the southern flank of the Llano uplift during three complete transgressive-regressive cycles of sedimentation (Stricklin and others, 1971). Each cycle is represented by a lithogenetic, time-stratigraphic sequence characterized by terrigenous clastic deposits near the base and marine carbonate sediments near the top. The rock record of each cycle, or "terrigenous clastic/marine carbonate couplet," is separated from the succeeding cycle by a disconformity. Each couplet generally onlaps rocks of the previous cycle and documents a major advance of the Early Cretaceous sea, terminated by an overall drop in sea level or some kind of equilibrium between land and sea. In depositional order, these couplets include: (1) the Sycamore Sand (Hosston Formation, downdip) and Sligo Formation; (2) the Hammett Shale (Pine Island Shale Member, downdip) and Cow Creek Limestone (Cow Creek Limestone Member, downdip); and (3) the Hensel Sand (Bexar Shale Member, downdip) and Glen Rose Limestone.

While detrital sand and gravel of the Sycamore Sand were deposited by aggrading streams on the southern flank of the Llano uplift (Inden, 1974), 


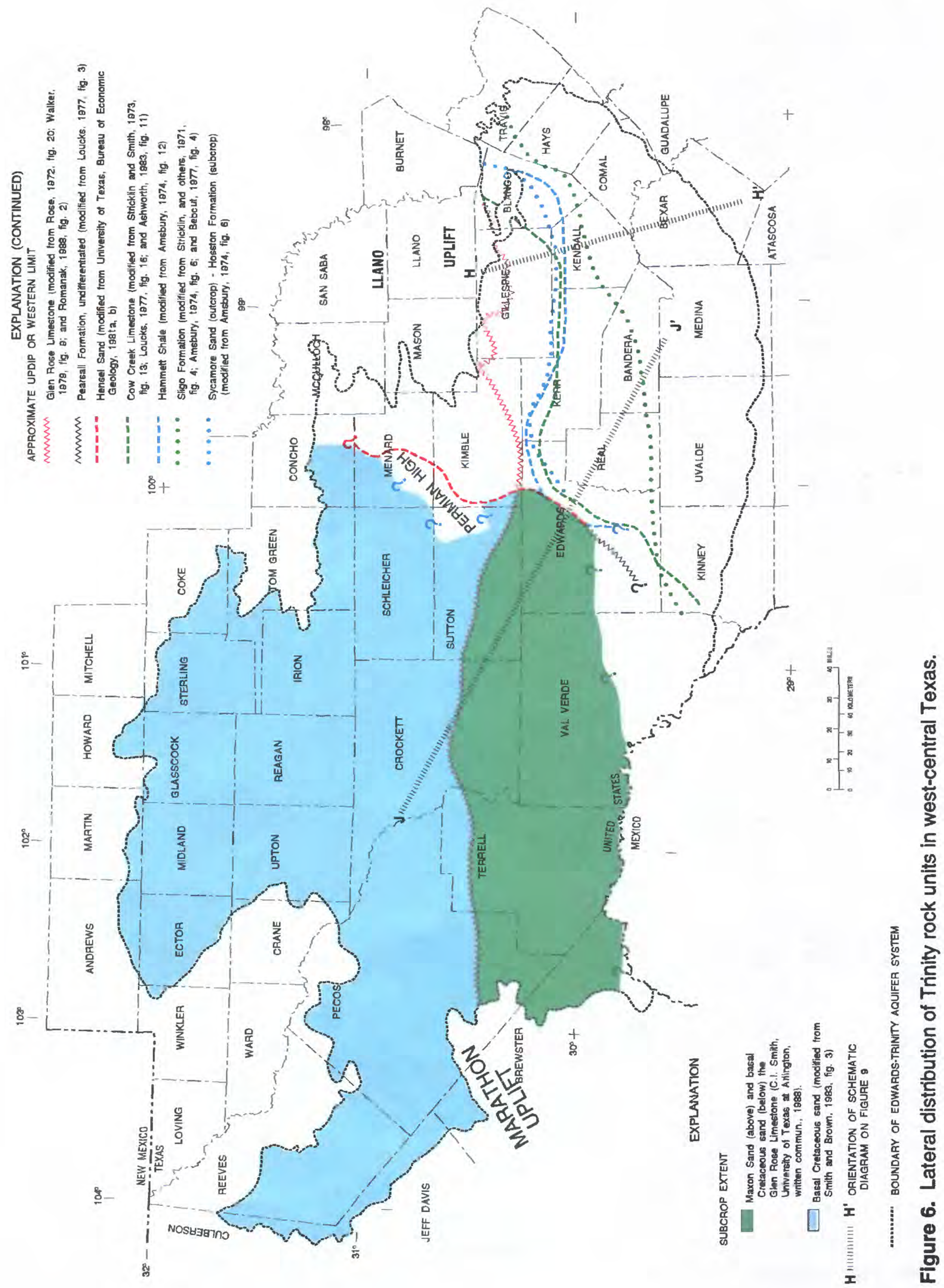

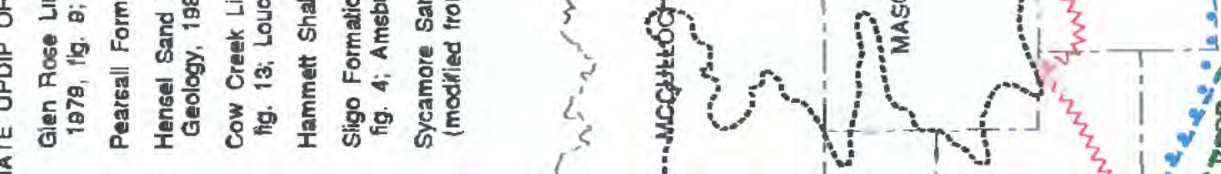




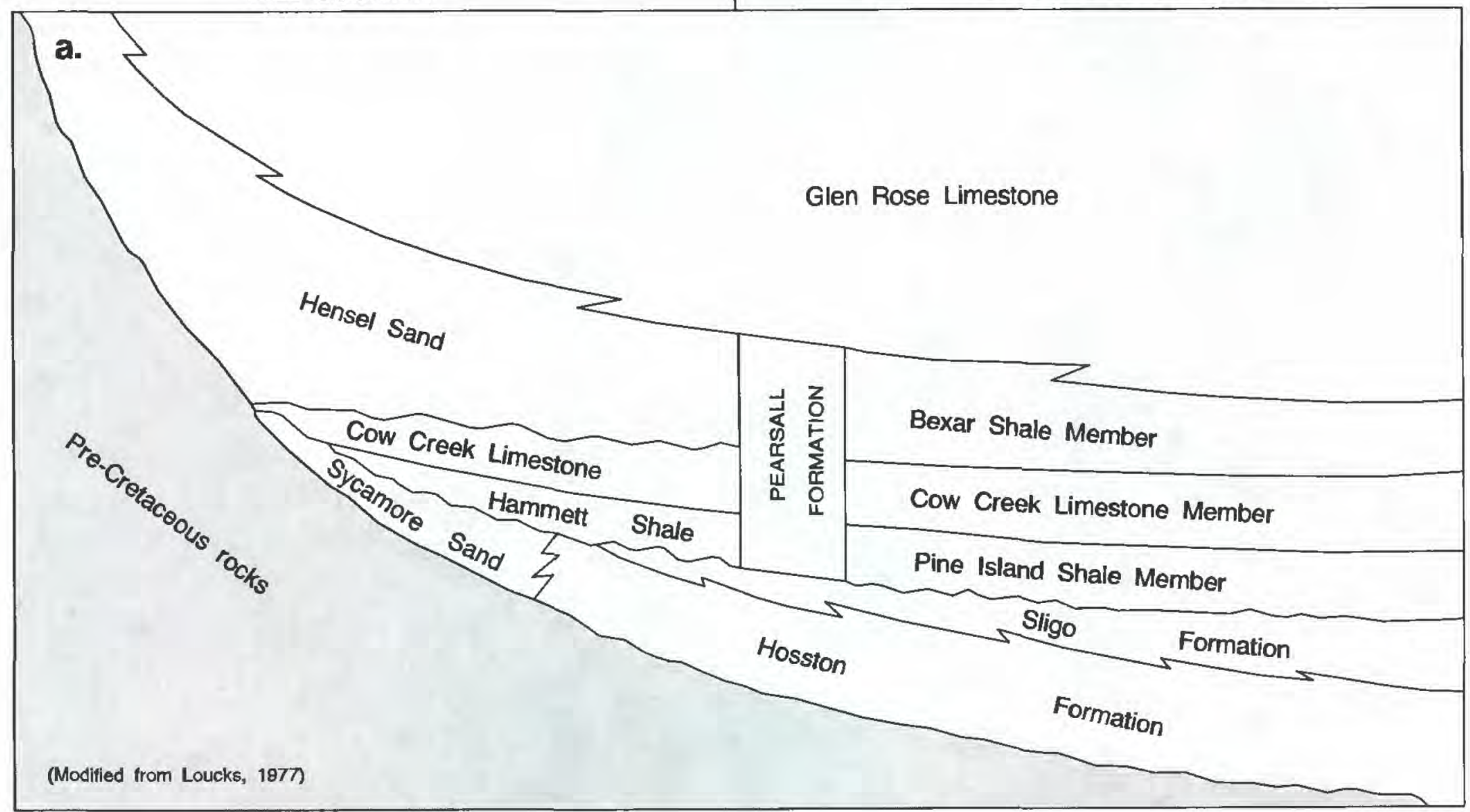

NOT TO SCALE

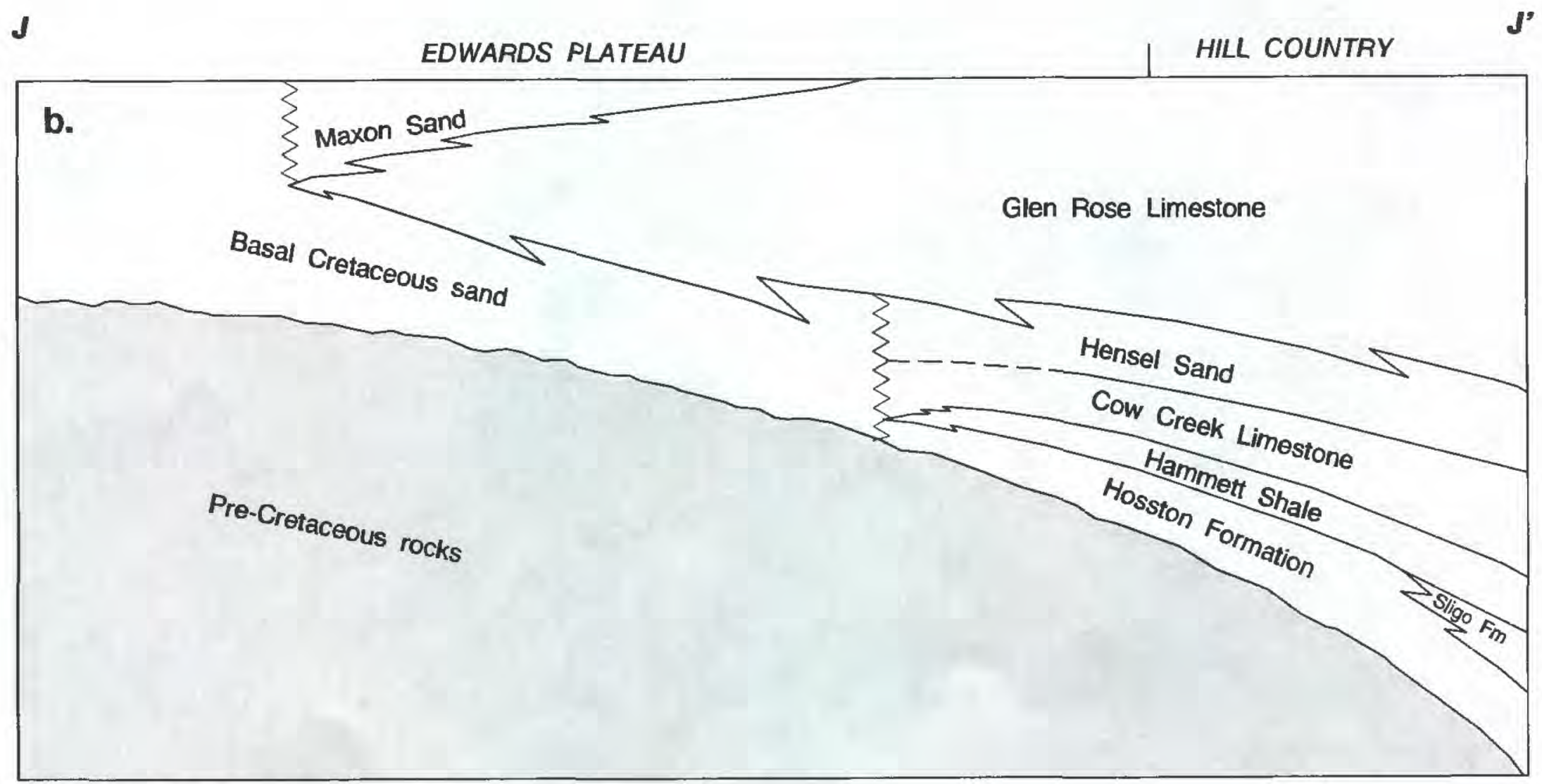

NOT TO SCALE

Figure 7. Vertical distribution of Trinity rock units in west-central Texas and their relation to geographic subareas. (See fig. 6 for orientation of diagrams.) 
calcareous mud and silt of the Hosston Formation (Bebout and others, 1981) accumulated offshore in a transgressing sea. Dolomitic siltstone and rhythmically bedded mudstone of the overlying Sligo Formation (Stricklin and others, 1971) were deposited in shallow, brackish water of a regressive sea with a shoreline that did not reach the updip limit (present outcrop area) of the Sycamore Sand (fig. 6).

Following a period of subaerial exposure and widespread cementation, the Trinity sea rapidly returned (Stricklin and others, 1971, p. 14). The argillaceous Hammett Shale was deposited atop slightly eroded upper surfaces of the Sycamore Sand and Sligo Formation. The dominant depositional environment of the Hammett Shale (and the downdip equivalent Pine Island Shale Member of the Pearsall Formation) was a wide, relatively unrestricted body of quiet water whose salinity ranged from normal marine to brackish (Amsbury, 1974).

The Cow Creek Limestone mostly formed as high-energy, beach-dominated environments prograded seaward from the Llano uplift (Stricklin and Smith, 1973). Lower parts of the unit appear to have been deposited offshore under gradually shoaling conditions. Coquina in the upper parts of the unit probably formed within a shoreline reentrant, where mollusk shells furnished by slackened longshore currents were sorted by waves refracted against the curved shoreline of the reentrant. High-gradient streams transported Precambrian igneous and metamorphic detritus and Paleozoic sedimentary rock fragments from the Llano uplift to the shoreline, where it mixed with the shell debris and extended the land area. As the reentrant filled and the shoreline stabilized, upper parts of the beach became subaerially exposed. An irregular topography and pockets of caliche developed atop parts of the Cow Creek Limestone, as unconsolidated sediments were redistributed by the wind and storm waves and meteoric water alternately leached and precipitated carbonate minerals.

Further subsidence in the ancestral Gulf of Mexico basin initiated the third and final major transgression of the Trinity sea. The Bexar Shale Member of the Pearsall Formation (Forgotson, 1957, p. 2,347) formed as a mixed, terrigenous clastic/carbonate facies in the "*** fine-grained distal part of a deltaic system" that prograded seaward from the Llano uplift (Loucks, 1977, p. 106). The Hensel Sand was deposited in the updip part of that system upon alluvial fans that coalesced into a lower-lying coastal plain, which merged on the south and east with the shallow-marine environment of the Bexar Shale. About this time, the basal Cretaceous sand (Romanak, 1988) began to form west of the Llano uplift as braided stream deposits accumulated atop the peneplained surface of Paleozoic and Triassic rocks (figs. 6, 7b).

As sandy red beds of the updip Hensel Sand formed in terrestrial settings on the flanks of the Llano uplift, the Glen Rose Limestone accumulated to the southwest (above the basal Cretaceous sand) and south (above the Bexar Shale) in comparatively low-energy, shallow-marine environments. During early Glen Rose time, rudist reefs flourished in pockets of highly circulated water of less than normal salinity (Perkins, 1974; Petta, 1977). The reefal structures vanished as hypersaline conditions dominated late Glen Rose time, in response to reduced water circulation and increased aridity (Stricklin and Amsbury, 1974). The upper member of the Glen Rose Limestone was deposited in restricted environments dominated by broad tidal flats in the lee of an incipient Stuart City reef trend (fig. 5) that began to build along the shelf edge during middle to late Trinitian time.

The rate of regional subsidence during middle to late Trinitian time was greatest toward the south. As a result, the thickness of the Glen Rose Limestone triples between central Sutton County and southern Kinney County. Jager (1942, p. 384) attributed this southward thickening to a rapidly sinking northern flank of the Rio Grande embayment (fig. 5). Trinity rocks in the study area were deposited on the northern flank of the Rio Grande Embayment (Murray, 1961, p. 128).

The sea withdrew from the study area during late Trinitian time. As the shoreline receded toward the south and east, the carbonate-producing marine environments of the Glen Rose Limestone were replaced in the southwestern part of the study area by a fluvialdeltaic system that deposited the Maxon Sand (King, 1980 , p. 21). While the Maxon Sand accumulated atop the Glen Rose Limestone between southern Pecos County and eastern Edwards County (fig. 6), a large mudflat dominated depositional conditions east of Edwards County. Thin beds of evaporitic, dolomitic, and marly strata accumulated on the mudflat in environments characterized by long periods of subareal exposure and cementation. Mudcracks, algal structures, ripple marks, dinosaur tracks, and mollusk borings characteristic of these environments were preserved near the top of the Glen Rose Limestone. About the end of Trinitian time, the shoreline withdrew 
Table 1. Correlation chart showing the chronostratigraphic, lithostratigraphic, and regional hydrogeologic units in

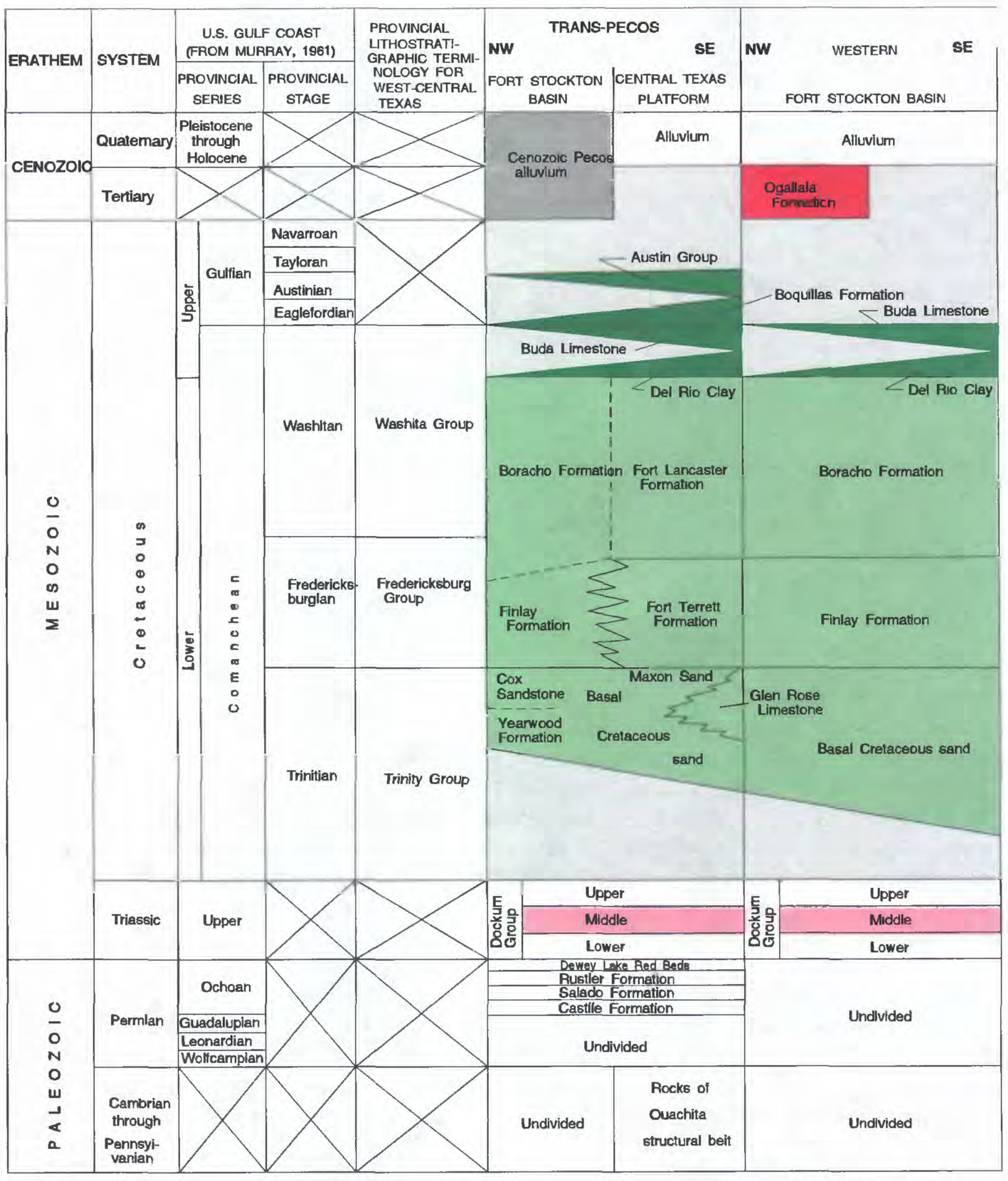

EXPLANATION

CENOZOIC PECOS ALLUVIUM AQUIFER

HIGH PLAINS AQUIFER 
the Edwards-Trinity aquifer system, west-central Texas

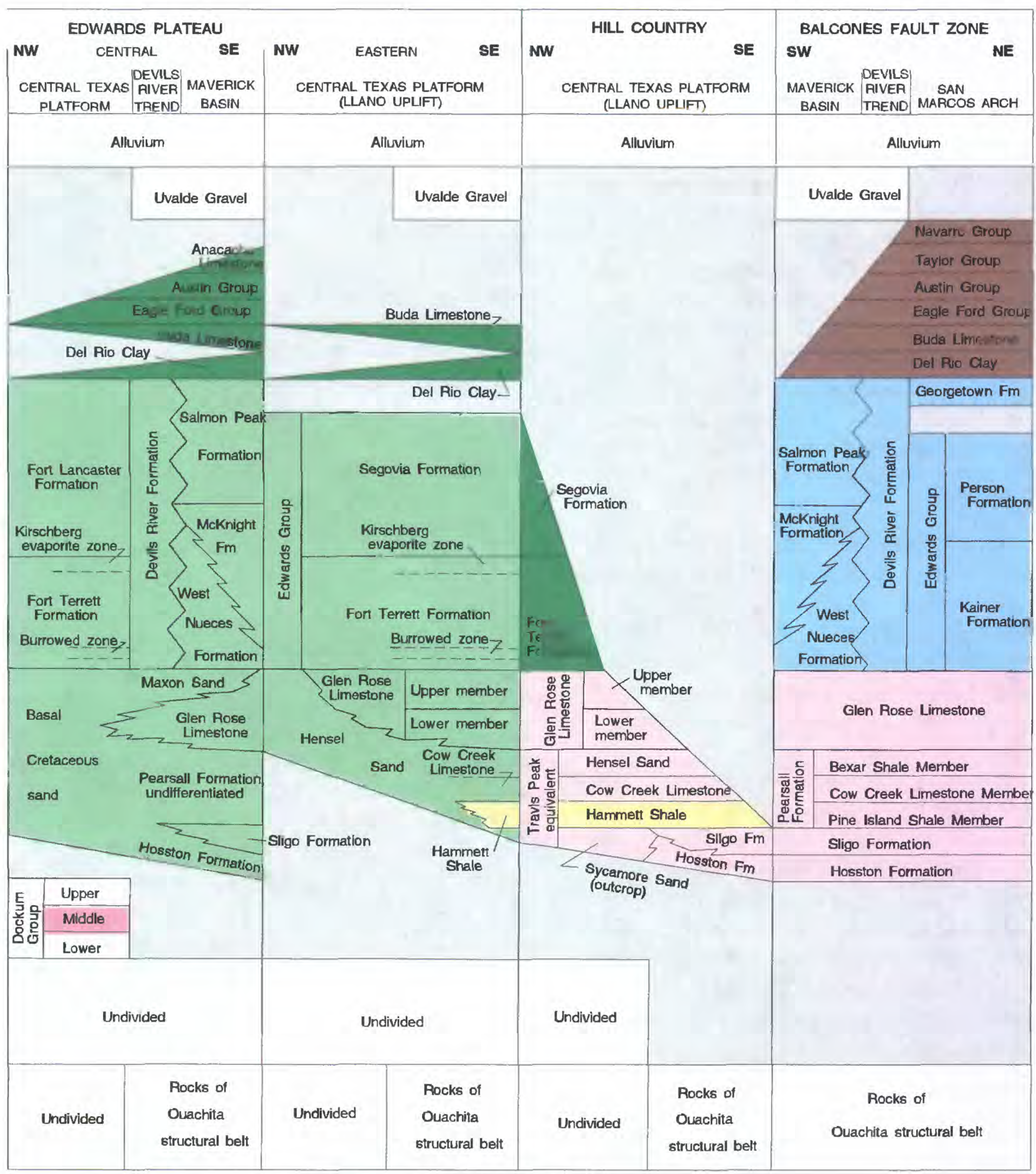

\section{EDWARDS-TRINITY AQUIFER SYSTEM}

\section{EXPLANATION (CONTINUED)}

Navarro-Del Rio confining unit

Edwards aquifer

Edwards-Trinity aquifer

Trinity aquifer

Hammett confining unit
DOCKUM AQUIFER

CRETACEOUS ROCKS NOT PART OF EDWARDS-

TRINITY AQUIFER SYSTEM BECAUSE THEY

ARE DISCONTINUOUS, UNSATURATED,

OR RELATIVELY IMPERMEABLE

ROCKS ABSENT 
to a position parallel to and slightly north of the present day Balcones fault zone (Lozo and Smith, 1964, p. 291).

\section{Comanchean Epoch: Fredericksburgian and Washitan Ages}

By early Fredericksburgian time, an offshore bioherm of rudists, corals, and carbonate deposits had grown to an almost continuous reef/island ridge along the seaward edge of the continental shelf in the ancestral Gulf of Mexico basin (Bebout and Loucks, 1974, p. 6). This shelf margin ridge, called the Stuart City reef trend (fig. 5), extended from northern Mexico across nearly $500 \mathrm{mi}$ of southeastern Texas (Winter, 1962). The aggressive upward growth of the Stuart City reef trend during early Fredericksburgian time probably resulted from a rapid rise in sea level that may have been triggered by an increase in the rate of seafloor spreading (Bay, 1977, p. 17).

The Stuart City reef trend sheltered depositional environments in the study area from the deep, openmarine conditions in the ancestral Gulf of Mexico basin. While water depths exceeded $1,000 \mathrm{ft}$ in the basin, they ranged from a few feet to generally less than $100 \mathrm{ft}$ on the landward margin of the continental shelf, or carbonate platform, where depositional environments were sheltered from strong wave and current forces. While dark, argillaceous sediments containing planktonic foraminifera accumulated basinward under generally reducing conditions, calcareous strata containing warm-water organisms formed in shallowmarine environments on the carbonate platform (Bebout and Loucks, 1974, p. 2-6). Evaporitic and dolomitic strata formed over higher parts of the carbonate platform on tidal flats, which frequently were subjected to subaerial exposure, oxidation, and erosion.

The Fredericksburg Group and most of the Washita Group of west-central Texas (table 1) were deposited leeward of the Stuart City reef trend upon a broad expanse of sea floor known as the Comanche shelf (Rose, 1972). According to C.I. Smith (University of Texas at Arlington, oral commun., 1989), sedimentation on the Comanche shelf was controlled by the (1) climate, (2) influx of terrigenous clastic sediment, (3) distribution of tectonic subsidence and uplift, and (4) energy level of wave and current action. The resulting lithofacies determined the stratigraphy and, together with the effects of subsequent tectonics and diagenesis, the hydraulic characteristics of rocks that today compose the Edwards-Trinity aquifer system.

Elements of the Comanche shelf that most strongly affected Fredericksburg and Washita deposition are shown schematically in figure 8. The lateral and vertical distributions of the resulting rock units are shown in figures 9 and 10 , respectively.

The central Texas platform was an elongated mound on the Comanche shelf that extended from northwest of the Llano uplift to approximately the San Angelo area (figs. 8, 9). The San Marcos arch, a comparatively narrow structural high, extended southeast from the Llano uplift to the Stuart City reef trend. By early Fredericksburgian time, the Llano uplift had eroded to a much less prominent feature on the central Texas landscape than it had been during Trinitian time. Because the central Texas platform and San Marcos arch merged across the Llano uplift, however, depositional environments in the study area generally were isolated from those of north Texas. The Maverick basin was a semioval depression near the southern margin of the Comanche shelf. The Devils River trend was a narrow carbonate bank composed largely of rudists and reefal debris that developed around the northern and western margins of the Maverick basin during middle Fredericksburgian through early Washitan time. The Devils River trend, together with the Stuart City reef trend, restricted the circulation of seawater and isolated depositional conditions in the Maverick basin. The Fort Stockton basin was a slowly subsiding, deep-water embayment that extended across the northwestern part of the Comanche shelf from northern Mexico.

During Fredericksburgian through early Washitan time, the central Texas platform was dominated by supratidal, intertidal, and restricted shallow-marine depositional environments. During periods of especially low sea level and extreme aridity, the crest of the central Texas platform became a broad, sabkha-type mudflat where evaporites, dolostone, and thin-bedded dolomitic limestone were deposited (Fisher and Rodda, 1966). Comparatively thick-bedded, rudist-bearing, bioclastic carbonate strata were deposited on the southwestern flank of the central Texas platform in mostly open shallow-marine to open-shelf environments. Here, the water typically was deeper and the circulation generally was less restricted than in the tidal flat environments that prevailed over the crest of the central Texas platform. Marly carbonate strata were deposited at this time in the Fort Stockton basin, an open-marine embayment of moderately deep, quiet water. 


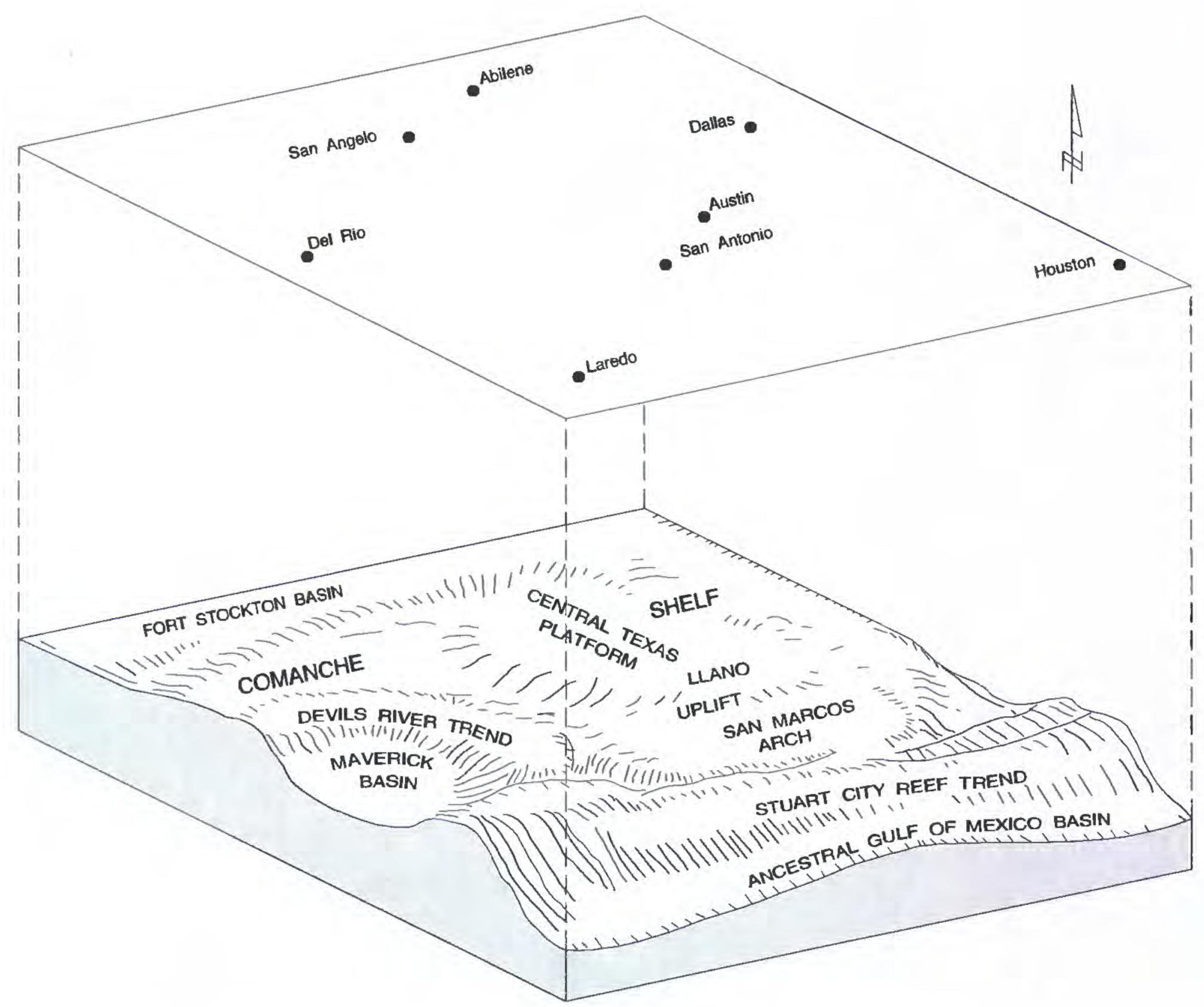

NOT SCALE

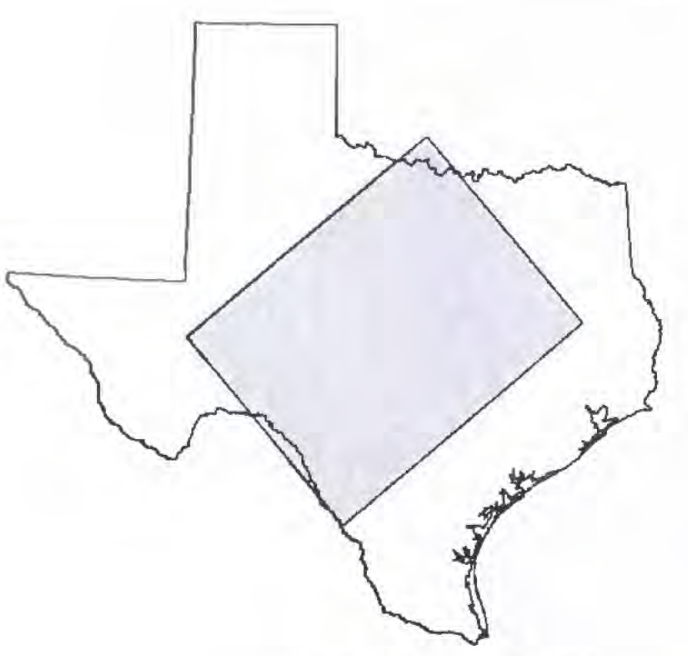

LOCATION MAP

Figure 8. Structural controls on the deposition of Fredericksburg and Washita strata of the Edwards-Trinity aquifer system. (Modified from Rose, 1972, fig. 2.) 


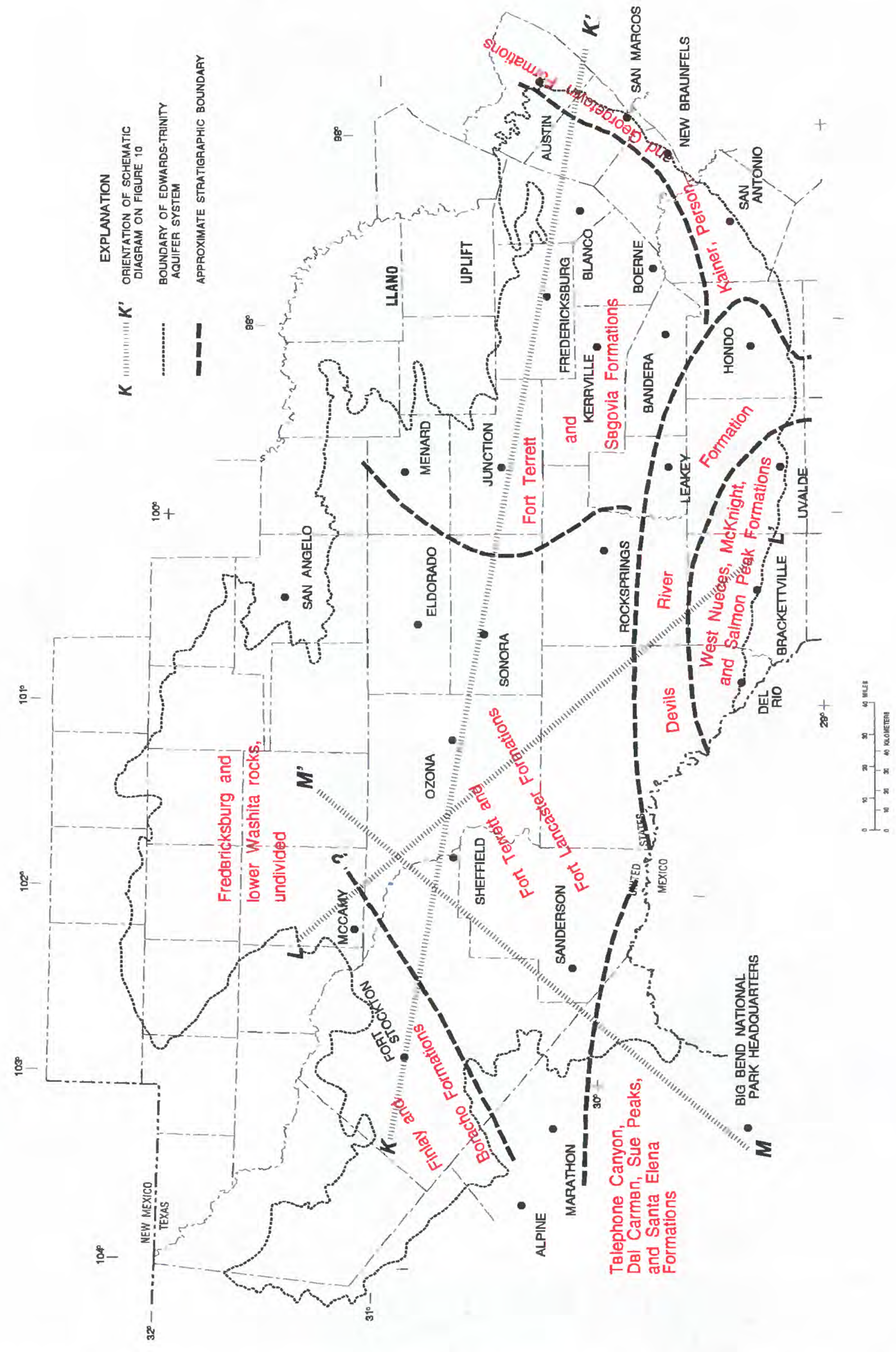

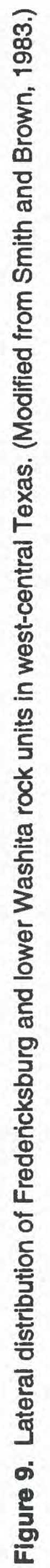




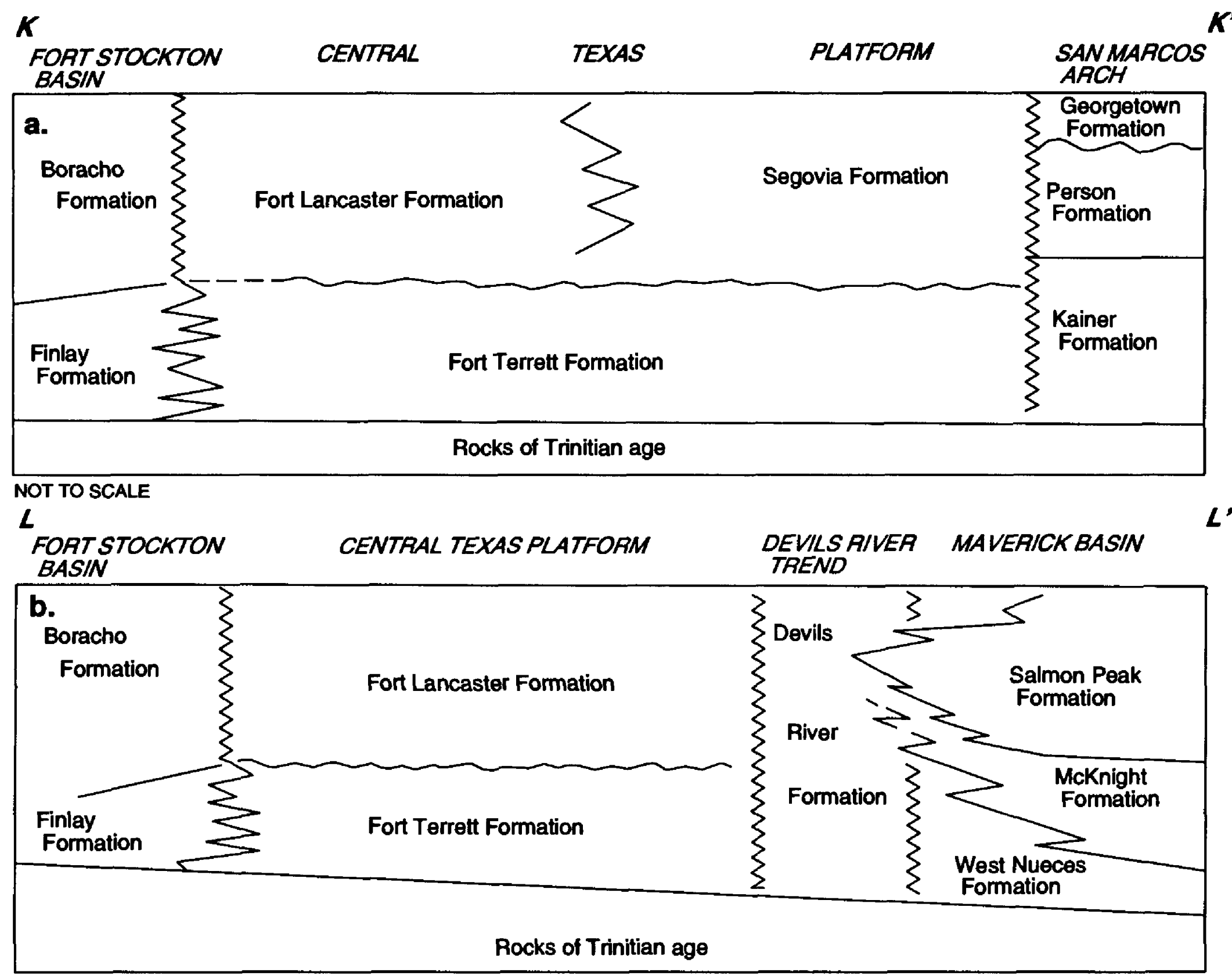

NOT TO SCALE
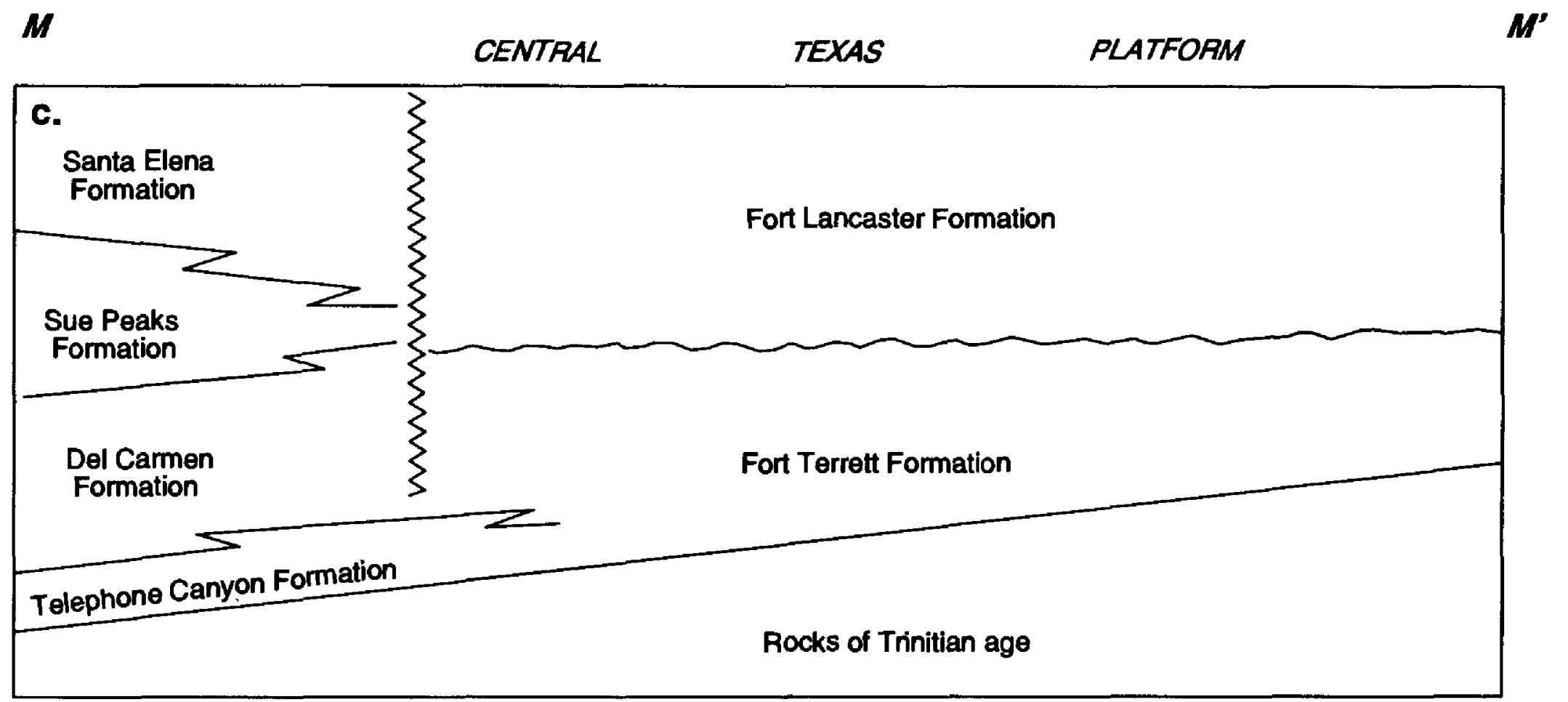

NOT TO SCALE

Figure 10. Vertical distribution of Fredericksburg and lower Washita rock units in west-central Texas (modified from Smith and Brown, 1983) and their relation to depositional environments. (See fig. 9 for orientation of diagrams.) 
The eastern part of the Fort Terrett Formation and the Segovia Formation (Rose, 1972) formed near the crest of the central Texas platform in mostly supratidal to restricted shallow-marine environments. The western part of the Fort Terrett Formation and the Fort Lancaster Formation (Scott and Kidson, 1977) formed in mostly open shallow-marine to open-shelf environments transitional to the central Texas platform and Fort Stockton basin.

The Finlay Formation, a cliff-forming limestone with quartz sand in the lower part and rudists in the upper part (Reaser and Malott, 1985), formed during Fredericksburgian time in the Fort Stockton basin when it mostly was a shallow, open lagoon. The Boracho Formation (Brand and Deford, 1958) was deposited later in a deeper, shelf-basin environment that received fine-grained terrigenous sediment from west of the study area. The fine-grained, siliciclastic nature of the Boracho Formation inhibited the precipitation of calcium carbonate and growth of rudists in the Fort Stockton basin during Washitan time (C.I. Smith, University of Texas at Arlington, oral commun., 1989).

The San Marcos arch was dominated by tidal flats and shallow water deposits that frequently underwent uplift, subaerial exposure, and erosion. The Kainer and Person Formations (Rose, 1972) that formed over this arch are characterized by lateral facies changes, structural thinning, and erosional surfaces.

While depositional environments on the central Texas platform and San Marcos arch mostly got shallower during Fredericksburgian through early Washitan time, major subsidence south of a tectonic hinge line (fig. 5) kept parts of southwestern Texas and northern Mexico more deeply submerged. The tectonic hinge line (Smith, 1981, p. 4) extended from the San Marcos arch westward across Medina, Uvalde, Kinney, and Val Verde Counties (fig. 2) to the Big Bend area of Texas (fig. 3). Greater rates of subsidence south of the hinge line triggered fundamental differences between the stratigraphy of rocks deposited on the central Texas platform and those deposited in the Maverick basin (C.I. Smith, University of Texas at Arlington, oral commun., 1989).

In contrast to many depositional breaks north of the tectonic hinge line, the persistently submerged Maverick basin received sediment almost continuously during Fredericksburgian and Washitan time. The typically restricted basin environments generally were isolated from those to the north by an intervening zone of comparatively good water circulation, moderate to high wave and current energy, and aggressive reef growth; the resulting bank of carbonate sediment and reefal debris is known as the Devils River trend (fig. 5). The Devils River trend, on the west and north, together with the Stuart City reef trend, on the east and south, nearly encircled the Maverick basin and thereby limited the extent of three lithofacies that are unique to the basin: the West Nueces, McKnight, and Salmon Peak Formations.

Bioclastic limestone of the West Nueces Formation (Lozo and Smith, 1964) formed mostly below wave base, generally under open-marine conditions of normal salinity. Evaporites near the base of the McKnight Formation (Miller, 1984) were deposited in slightly restricted intertidal and subtidal environments on a broad mudflat that sloped inland from the Stuart City reef trend. As the rate of subsidence increased south of the tectonic hinge line (fig. 5) and the water deepened toward the center of the Maverick basin, gypsiferous deposits that compose lower parts of the McKnight Formation prograded northward. Thinbedded, finely laminated middle parts of the McKnight Formation formed in an euxinic lagoonal environment (Carr, 1987, p. 70) that produced raw sulfur, petroliferous shale, and dark organic-rich limestone. After the water freshened slightly, thin beds of anhydrite and clayey, lime mudstone accumulated in water approximately 150 to $200 \mathrm{ft}$ deep and formed upper parts of the McKnight Formation (C.I. Smith, University of Texas at Arlington, oral commun., 1989). The McKnight Formation was covered with thick beds of relatively pure lime mudstone that characterize the lower two-thirds of the Salmon Peak Formation (Humphreys, 1984). The lower few hundred feet of Salmon Peak Formation amassed in open to slightly restricted basinal environments, where the water was approximately 300 to 600 $\mathrm{ft}$ deep. Conditions became less restricted toward the end of Salmon Peak deposition (middle Washitan time), as the Stuart City reef trend began to disintegrate and the connection between the Maverick basin and the open sea improved (C.I. Smith, University of Texas at Arlington, oral commun., 1989).

Concurrent with deposition inside the Maverick basin, the surrounding Devils River trend produced a stratigraphically undifferentiated bank of partly to completely dolomitized miliolid, shell-fragment, and rudist-bearing limestone (Lozo and Smith, 1964, p. 291-297). Nodular, burrowed, dolomitic, and evaporitic rock sequences that compose the lower half of the Devils River Formation (Miller, 1984) were laid down 
during Fredericksburgian time. During most of Washitan time, rudist reefs flourished around the northern perimeter of the Maverick basin in open, shallowmarine environments of moderate to high wave and current energy. These reefs may have stood above sea level intermittently during middle to late Washitan time when extensive leaching, dolomitization, and recrystallization occurred here, as well as in other parts of the study area (R.W. Maclay, U.S. Geological Survey, written commun., 1987).

Most of the central Texas platform was exposed subaerially, following a widespread withdrawal of the sea toward the end of early Washitan time in response to an upwarping of the Comanche shelf (Rose, 1972, p. 71). Approximately $100 \mathrm{ft}$ of lower Washita strata were eroded from the crest of the San Marcos arch, where upper surfaces of the remaining rocks were karstified (Maclay and Small, 1983, p. 130). Soil and caliche horizons developed toward the north and west over emergent parts of the central Texas platform (Smith and Brown, 1983, p. 23). Freshwater marl and limestone (Halley and Rose, 1977, p. 213-215) formed in marshy, lower-elevation environments toward the south and east. Caverns and other karstic features in the Edwards Plateau (Kastning, 1983, fig. 3) and in the Balcones fault zone (Hammond, 1984, fig. 15) probably began to form during this middle Washitan exposure to meteoric conditions (fig. 11). The local regimes of freshwater circulation suggested by Ellis (1986, p. 110) would have helped flush soluble constituents from the shallow subsurface.

The open sea eventually returned and covered the San Marcos arch with the Georgetown Formation, a nodular, slightly argillaceous, generally thin-bedded limestone. Upper parts of the Segovia and Fort Lancaster Formations were deposited at this time over the central Texas platform, as bioclastic lime sand and mud were laid down in relatively shallow, agitated water (Rose, 1972, p. 71). A shoaling-upward pattern of deposition prevailed around the northern margin of the Maverick basin. As a result of higher wave and current energy and a greater reworking of sediments near the Devils River reef bank, a tongue of relatively pure lime grainstone prograded southward into the Maverick basin, forming the upper part of the Salmon Peak Formation. The rate of reef growth at this time probably exceeded the rate of subsidence in the Maverick basin (Humphreys, 1984, p. 56).

Following regional uplift during late Washitan time and additional erosion of sediments from the crest of the central Texas platform, the open sea once again returned to west-central Texas. The Comanche shelf was blanketed with silt, clay, and marly limestone of the Del Rio Clay. This relatively thin (table 2), openmarine terrigenous deposit topped the Maverick basin, which by late Washitan time was no longer characterized by distinct depositional environments. Carbonate sedimentation abated as the suspended sediment obstructed the feeding of carbonate-producing organisms in environments no longer sheltered within the Maverick basin or behind the Stuart City reef trend (C.I. Smith, University of Texas at Arlington, oral commun., 1989).

Additional uplift and emergence of the central Texas Platform just before the end of Washitan time caused erosion to strip some, and in places all, of the upper Washita strata from the study area. The Washitan age ended as the deep sea returned and blanketed the entire study area with a thin sheet of open-shelf lime mudstone, known as the Buda Limestone.

\section{Gulfian Epoch: Eaglefordlan Through Navarroan Ages}

During Eaglefordian (early Gulfian) through Navarroan (late Gulfian) time, the Buda Limestone was covered with 2,000 to perhaps $4,000 \mathrm{ft}$ of sandstone, shale, marl, and chalk (Waters and others, 1955, p. 1,831). Except for Eagle Ford sediments in western parts of the study area, most Gulf strata formed under low-energy, open-shelf conditions. Most Gulf strata in the study area are fine-grained, strongly cemented, and virtually impermeable.

The study area was uplifted at the close of the Cretaceous Period, in response to the Laramide orogeny of northern Mexico and the southwestern part of the United States (Ewing, 1991, p. 24). Extensive erosion subsequently removed most Gulf sediments from the study area. The remaining rocks include those of Late Cretaceous age that dip steeply below land surface east of the Ouachita structural belt (fig. 4) and thin, sparse remnants of the Austin Group and Boquillas Formation atop the Edwards Plateau and Trans-Pecos. The Cretaceous System of the study area thus is separated from the Cenozoic Erathem by a major unconformity (Adkins, 1933, p. 517). 

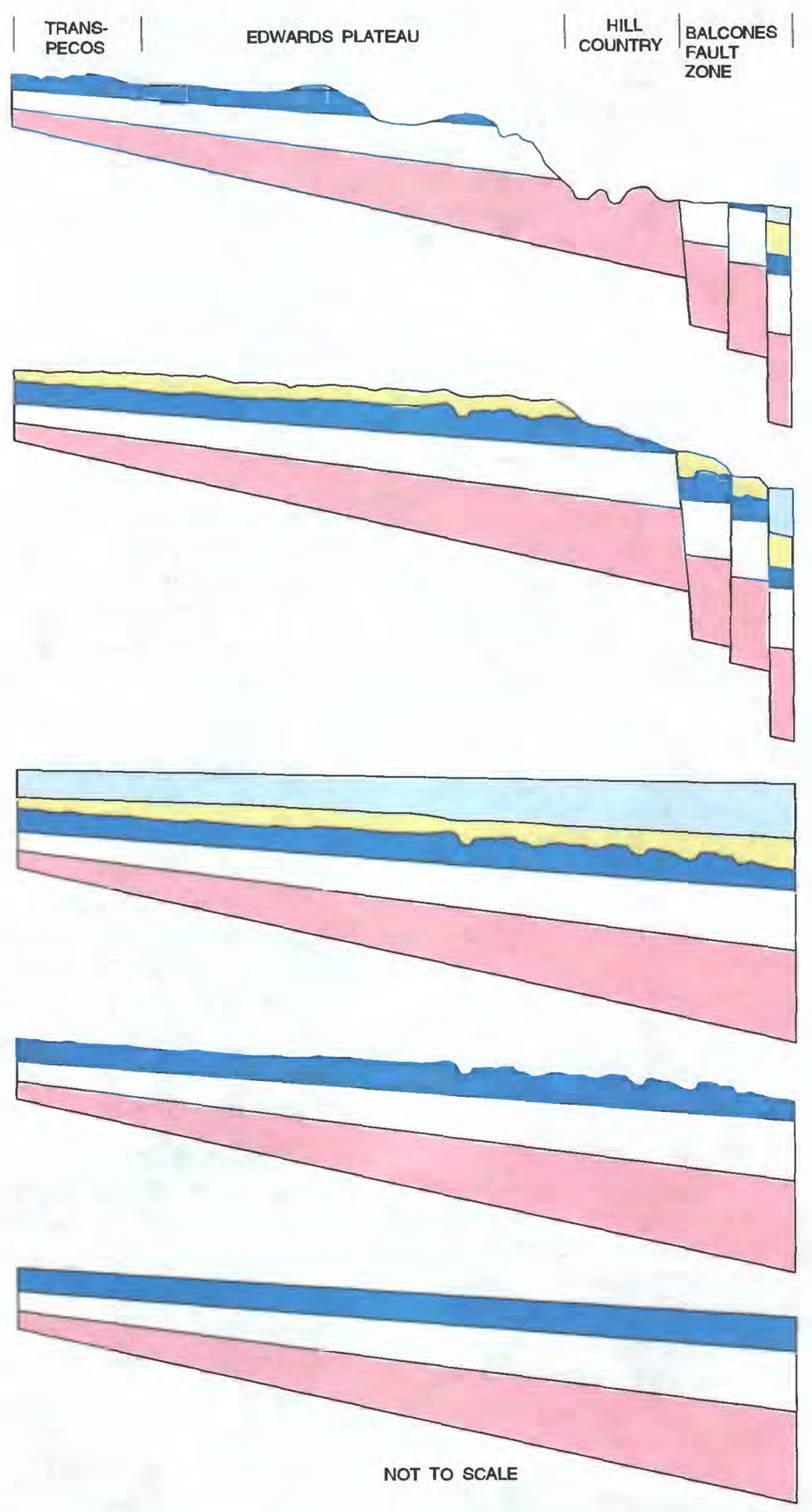

Figure 11. Progression of major depositional, tectonic, and diagenetic events affecting the development of the Edwards-Trinity aquifer system. 


\section{QUATERNARY}

Base level of surface drainage lowers as streams erode deeper into uplifted strata west of Balcones fault zone; Hill Country stripped of most post-Trinity strata; hydraulic conductivity of strata outside fault zone decreases through cementation, recrystallization, and replacement; hydraulic conductivity of Edwards Group inside fault zone increases through dissolution and dedolomitization; joint cavities, solution channels, and honeycombed zones continue to enlarge--increasing the transmissivity of Edwards aquifer; dynamic equilibrium between freshwater and saline water reached across freshwater/saline-water transition zone.

\section{TERTIARY: Oligocene - Miocene Epochs}

Cretaceous strata displaced vertically as much as 1,200 feet in Balcones fault zone by high-angle normal faults, culminating tensional buildup in strata above Ouachita structural belt, as Gulf of Mexico subsides; fractures in fault zone widen as erosional unloading progresses; ground-water flow diverted toward northeast by barrier faults; hydraulic conductivity increases through dissolution of previously buried evaporites, magnesium calcite, and aragonitic constituents as meteoric water enters faulted terrain and circulates through fractures and downdropped paleokarst; dolomite replaced by calcite through dedolomitization; micrite recrystallizes to coarse microspar and pseudospar; headward erosion toward upthrown Edwards Plateau initiates dissection of terrain west of fault zone; Gulf strata eroded and redeposited gulfward.

\section{LATE CRETACEOUS}

Karst, marl, soil, and caliche surfaces buried by upper Washita strata (following regional subsidence) and Gulf strata (following collapse of Stuart City reef trend); calcite cementation abates; karst development ceases; carbonate sediments undergo compaction, with stylolitization in deeply buried facies.

\section{LATE-EARLY CRETACEOUS: Following middle Washitan uplift}

Lower Washita strata exposed subaerially following uplift of Comanche shelf; approximately 100 feet of strata eroded from crest of San Marcos arch; San Marcos arch and central Texas platform locally karstified; primary porosity enlarged through dissolution of evaporitic and calcareous constituents in shallow zones of freshwater circulation, with carbonate cementation downgradient; freshwater marl, soil, and caliche horizons formed over central Texas platform.

\section{EARLY CRETACEOUS}

Trinity, Fredericksburg, and lower Washita strata deposited mainly in terrestrial, supratidal, intertidal, and shallow marine environments on slowly subsiding carbonate platform in lee of Stuart City reef trend; aragonitic constituents, high-magnesium calcite, and evaporites leached early by locally circulated meteoric water; breccia zones formed by collapse of overlying beds: supratidal carbonate deposits dolomitized and gypsum precipitated; aragonite and magnesium calcite cements formed in marine environments.

Figure 11. Continued.

\section{EXPLANATION} GULF ROCKS

Eaglefordian Ihrough Navarroan age COMANCHE ROCKS

\author{
Late Washitan age
}

Early Washitan age

Fredericksburgian age

Trinitian age 
Table 2. Approximate maximum thickness of lithostratigraphic units that compose the Edwards-Trinity aquifer system, west-central Texas

\begin{tabular}{|c|c|}
\hline Lithostratigraphic unit & Sources of thickness data \\
\hline 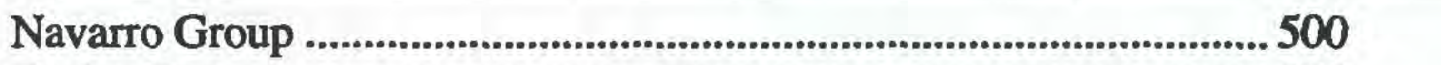 & Maclay and Small, 1986, table 1 \\
\hline Taylor Group & 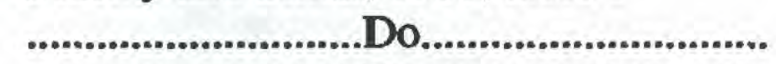 \\
\hline Austin Group & 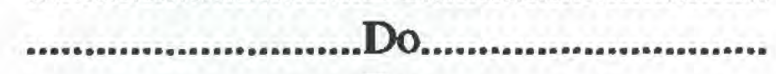 \\
\hline Eagle Ford Group & 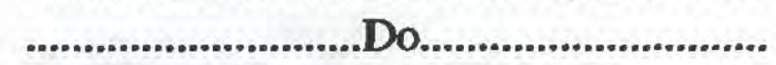 \\
\hline 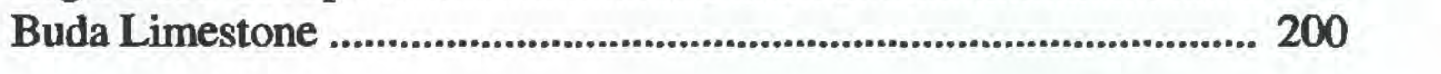 & Small and Ozuna, 1993, table 1 \\
\hline 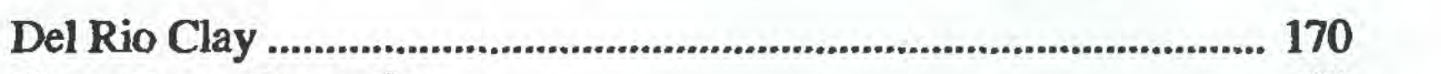 & C.I. Smith, written commun., 1989 \\
\hline Georgetown Formation & Rose, 1972 , fig. 16 \\
\hline Salmon Peak Formation & Humphreys, 1984, fig. 2 \\
\hline 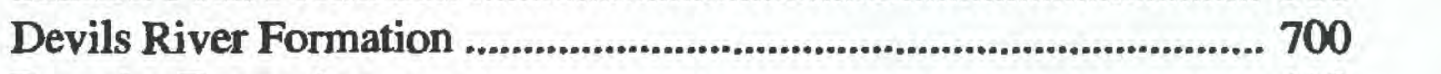 & Maclay and Small, 1986, table 1 \\
\hline Boracho Formation & Brand and DeFord, 1958, fig. 2 \\
\hline Fort Lancaster Formation & C.I. Smith, written commun., 1989 \\
\hline Segovia Formation & Rose, 1972, fig. 23 \\
\hline Person Formation & Rose, 1972, fig. 15 \\
\hline 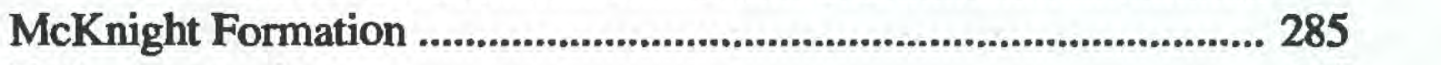 & Carr, 1987, p. 21 \\
\hline Finlay Formation & Small and Ozuna, 1993, table 1 \\
\hline Fort Terrett Formation & Rose, 1972, fig. 21 \\
\hline West Nueces Formation & Miller, 1984, p. 9 \\
\hline 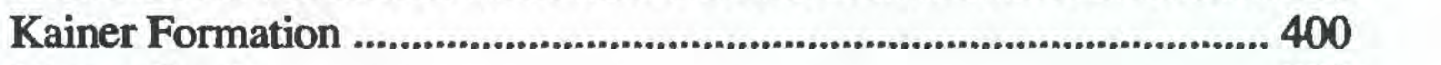 & Rose, 1972 fig. 14 \\
\hline 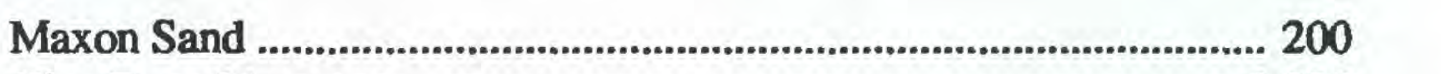 & C.I. Smith, written commun., 1989 \\
\hline Glen Rose Limestone & Welder and Reeves, 1964, table 1 \\
\hline Cox Sandstone & Brand and DeFord, 1958, fig. 2 \\
\hline Yearwood Formation & 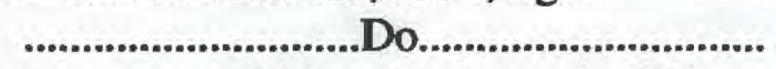 \\
\hline 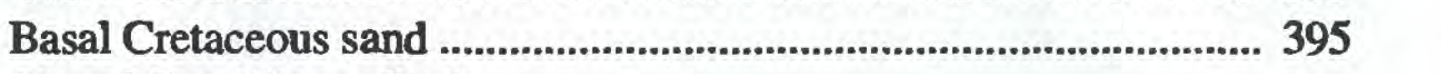 & Romanak, 1988, p. 21; Wessel, 1988 \\
\hline \multicolumn{2}{|l|}{ Hensel Sand/Bexar Shale } \\
\hline Member of Pearsall Formation ......................................................... 210 & Imlay, 1945, table 2 \\
\hline \multicolumn{2}{|l|}{ Cow Creek Limestone/Cow Creek Limestone } \\
\hline \multicolumn{2}{|l|}{ Hammett Shale/Pine Island Shale } \\
\hline Member of Pearsall Formation ..................................................... 130 & Amsbury, 1974, fig. 12 \\
\hline Sycamore Sand & DeCook, 1963, table 3 \\
\hline 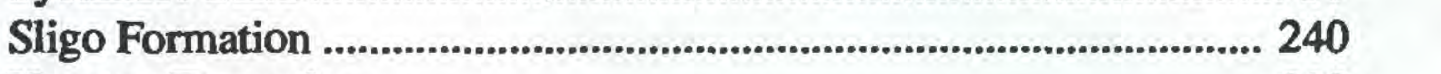 & Imlay, 1945, table 2 \\
\hline 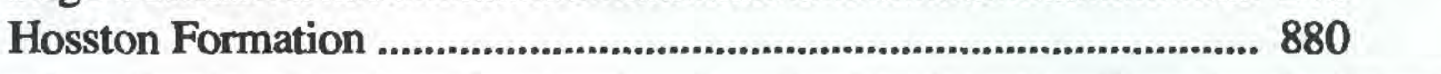 & 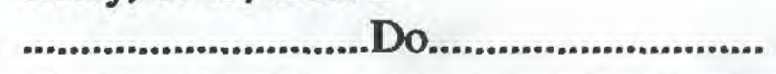 \\
\hline
\end{tabular}

\section{Cenozoic Era}

The majority of Cenozoic deposition in Texas (Wilhelm and Ewing, 1972) occurred southeast of the study area in the ancestral Gulf of Mexico basin (fig. 5). During the Cenozoic Era, a thick succession of offlapping deltaic deposits built the Gulf Coastal Plain with detritus eroded from Paleozoic and Mesozoic rocks on the uplifted continental interior (Wilhelm and Ewing, 1972). The most important Cenozoic units in the study area are: (1) narrow streambeds of Holocene alluvium; (2) sparse remnants of Pleistocene terrace deposits; and (3) thick deposits of Tertiary and Quaternary alluvium along the Pecos River. Only the thick alluvium along the Pecos River markedly affect the Edwards-Trinity aquifer system.

A large volume of Cretaceous strata was removed from the study area as a result of post-depositional dissolution, structural collapse, and stream erosion along the present course of the Pecos River (fig. 2). 
During the late Mesozoic and early Cenozoic Laramide deformation (Henry and Price, 1985), large solution cavities formed in the underlying Permian strata as halite, gypsum, and anhydrite were dissolved by ground water (Maley and Huffington, 1953). The entry of meteoric water was enhanced by the effects of a general crustal instability and the mobility of massive salt deposits in the region (Wessel, 1988, figs. 11-14). As the overlying Triassic and Cretaceous strata collapsed into the solution cavities, two elongated troughs (Barker and Ardis, in press, pl. 2) formed between the southeastern corner of New Mexico and the northwestern part of Pecos County (Ashworth, 1990, fig. 5). The troughs filled during Tertiary and Quaternary time with more than $1,500 \mathrm{ft}$ of talus and alluvial fill, known as the Cenozoic Pecos alluvium.

Since late Mesozoic time, mountain-building forces in the Trans-Pecos have uplifted western parts of the study area, while sediments east of the Ouachita structural belt mostly have subsided (Walper and Miller, 1985). Tensile stresses accumulated in the Cretaceous strata where they stretched over a sunken, but structurally rigid Ouachita structural belt (Flawn, 1956, p. 32). The crustal tension culminated during the Tertiary Period with a series of discontinuous, generally en echelon, mostly down-to-the-southeast, normal faults (figs. 4, 5). Although the majority of large-scale faulting probably was during late Oligocene through early Miocene time (Weeks, 1945, p. 1,736), some Late Cretaceous (or earlier) movement on some faults is possible (Murray, 1961, p. 176).

The Balcones fault zone is aligned with the curvature, and approximately with the axis, of the Ouachita structural belt (fig. 5). The Balcones faults disrupt Lower Cretaceous through Paleocene strata at the surface (Murray, 1961, p. 176) and appear to extend into and displace rocks of the underlying structural belt (Maclay and Small, 1986, fig. 2). The alignment of the Balcones faulting probably was influenced by lines of weakness in the Ouachita structural belt (Flawn and others, 1961, p. 190). Maximum displacements occurred over the San Marcos arch in Bexar, Comal, Hays, and Travis Counties. Weeks (1945, p. 1,734) estimated the total displacement across the Balcones fault to be about 1,200 ft near San Antonio and about $900 \mathrm{ft}$ near Austin.

The Balcones faulting (fig. 11) disrupted the lateral continuity of the Cretaceous strata and initiated hydrogeologic conditions that ultimately produced one of the most transmissive and productive aquifers in the
Nation: the Edwards aquifer of the Balcones fault zone (Maclay and Small, 1986). The Cretaceous strata in this area were downfaulted, intensively fractured, and differentially rotated within a series of northeast-trending fault blocks. Ground-water flow shifted toward the northeast in response to high-angle barrier faults that impeded or completely blocked southeastward flow. Flowpaths became increasingly ingrained toward the northeast as evaporites and unstable carbonate constituents dissolved from the fractured terrain and discharged in that direction through springs and deeply entrenched streams (Abbott, 1975).

Springs originated in topographically low areas, where barrier faults intercepted the lateral flow of confined water at depth and diverted it to the surface along avenues of least resistance (Abbott, 1977). Aquifers developed as flowpaths converged toward spring outlets, and the rocks became more permeable through dissolution. Solution channels spread outward from the springs, and zones of honeycombed and cavernous porosity evolved into major conduits of ground-water flow (Woodruff and Abbott, 1986, p. 77). The major springs (fig. 3) persisted and control modern potentiometric levels and discharge patterns (Bush and others, 1993).

Gulf-bound streams, that had been low-gradient, meandering features before the faulting, were out of equilibrium with the faulted topography (Woodruff and Abbott, 1986, fig. 5). Although most of the pre-fault watercourses had flowed generally eastward, headward erosion by newly formed (post-fault) streams progressed quickly northwestward across the Balcones escarpment toward the Edwards Plateau (Woodruff and Abbott, 1986). Many of the older, east-trending streams were pirated by the younger, higher-gradient streams that developed normal to the escarpment. According to Woodruff and Abbott (1986, p. 87), greater rates of stream incision began after piracy when more discharge became available from the newly acquired headwaters. Once the rejuvenated stream network breached the overburden of low-permeability Gulf rocks and cut into the relatively permeable Comanche rocks, the streams became discharge areas for developing aquifers.

Erosion eventually removed all but minor remnants of the Fredericksburg and Washita strata (mostly of the Edwards Group) from a 20- to 50-mile-wide area between the Balcones fault zone and the Edwards Plateau (fig. 3). The extensively dissected Hill Country is characterized by expansive outcrops of Glen Rose 
Limestone (of the Trinity Group). Because the rocks in the Hill Country generally were excluded from the vertical displacement, intensive fracturing, and subsequent dissolution that characterize those in the Balcones fault zone, the hydraulic properties of the Hill Country more closely resemble those of the Edwards Plateau and Trans-Pecos.

Outside the Balcones fault zone, the dominant effects of carbonate diagenesis (Bathurst, 1975) on the hydraulic characteristics of the Edwards-Trinity aquifer system result most importantly from cementation, recrystallization, and neomorphism. Neomorphism is a comprehensive term to describe processes of recrystallization and replacement where the mineralogy may have changed or it is impossible to distinguish between the mechanism of change. Most of the primary intergranular porosity partly or completely filled through cementation, and much of the original intercrystalline porosity decreased through successive stages of recrystallization. Unstable minerals, such as high-magnesium calcite and aragonite, mostly were replaced by relatively stable low-magnesium calcite. Because cementation, recrystallization, and replacement typically reduce or obliterate the porosity of carbonate rocks (Choquette and Pray, 1970, p. 209), the hydraulic conductivity of most rocks in the study area decreased over geologic time. The trend of decreasing hydraulic conductivity with increasing age is typical of carbonate rocks (Jakucs, 1977, p. 69; fig. 16).

Within the Balcones fault zone, however, the hydraulic conductivity generally has increased through the effects of tectonic fracturing and freshwater diagenesis in humid, post-Cretaceous environments (Maclay and Small, 1986, p. 28-32). In addition to creating porosity (Howard and David, 1936), the fractures enhanced hydraulic conductivity by interconnecting existing pores. The subsequent dissolution of unstable carbonate constituents resulted in vugs, channels, caverns and various kinds of fabric-selective porosity (Choquette and Pray, 1970, fig. 2) that additionally enhanced hydraulic conductivity. Because fractures typically close with increasing depth below land surface and dissolution is most active within the shallower zones of water-level fluctuation (LeGrand and Stringfield, 1971, p. 1,286), the increases in hydraulic conductivity generally are limited to rocks nearest the land surface.

A shallow, freshwater-flow regime probably has existed in the Balcones fault zone since Miocene time (Ellis, 1986), when large-scale faulting ruptured the thick overburden of hydraulically tight Gulf strata and exposed the more permeable upper Comanche strata to meteoric conditions (fig. 11). Previously leached strata (paleokarst) provided an incipient network of groundwater circulation that fostered aquifer development (Hammond, 1984, p. 149). The concentration of highangle faults and associated fractures facilitated the percolation of carbon-dioxide-enriched meteoric water, extending the depth of freshwater diagenesis. The partial pressure of the dissolved carbon dioxide, derived from the atmosphere and soil, increased the solubility of carbonate minerals. The vertically displaced terrain provided steep hydraulic gradients that maintained relatively large flow velocities near the surface and helped flush dissolved constituents. Hydraulic conductivity increased as evaporites (principally anhydrite and gypsum) and unstable carbonate constituents (aragonite and high-magnesium calcite) dissolved along fractures, bedding planes, and burrows (Abbott, 1975, p. 255267).

The hydraulic conductivity of dolostone in the Balcones fault zone increased through dedolomitization (Maclay and Small, 1986, p. 31), a form of incongruent dissolution, where dolomite in combination with dissolved gypsum is replaced by calcite. Dedolomitization, by itself, does not increase hydraulic conductivity. However, the resulting "calcite after dolomite," or dedolomite, can be more soluble than the original dolomite; subsequent dissolution can then increase hydraulic conductivity. The presence of dedolomite to depths of about $600 \mathrm{ft}$ on the freshwater side of the freshwater/saline-water transition zone (fig. 2) is evidence that most dedolomitization in the Balcones fault zone occurred since Miocene time-after a dynamic, freshwater-flow regime was established (Ellis, 1986, p. 109). Most dedolomite in the area of the Edwards aquifer formed during the last 15 to 20 million years, according to R.W. Maclay of the U.S. Geological Survey (written commun., 1990).

The transmissivity of the Edwards aquifer is much greater than that of the other aquifers in the study area. Whereas transmissivity values for the Edwards aquifer (covering less than 10 percent of the study area) average about $750,000 \mathrm{ft}^{2} / \mathrm{d}$, transmissivity values for the Trinity and Edwards-Trinity aquifers (covering more than 90 percent of the study area) average less than $10,000 \mathrm{ft}^{2} / \mathrm{d}$ (E.L. Kuniansky, U.S. Geological Survey, written commun., 1990).

The difference between the transmissivity of the Edwards aquifer and the transmissivity of the Trinity 
aquifer in the Balcones fault zone is attributable to the effects of fractures that close with increasing depth below land surface and a history of larger flow velocities near the surface. The Balcones faulting steepened hydraulic gradients and initiated a shallow, dynamic flow system that promoted dissolution, which enhanced the transmissivity of the Edwards aquifer. In contrast, cementation, recrystallization, and mineral replacement - caused by deeper, comparatively sluggish ground-water circulation-combined to diminish the transmissivity of the underlying Trinity aquifer, as well as most strata outside the fault zone.

The transmissivity of the Trinity aquifer in the Hill Country and the Edwards-Trinity aquifer in the Edwards Plateau and Trans-Pecos, likewise, is small compared with the transmissivity of the Edwards aquifer in the Balcones fault zone. Secondary calcite fills most of the original pores in the carbonate rocks outside the Balcones fault zone, where joint cavities and solution channels associated with large-scale normal faulting and subsequent dissolution are relatively sparse. Variations in transmissivity outside the fault zone probably result more from differences in saturated thickness (Ardis and Barker, 1993) than from diagenetic and post-depositional tectonic activity.

\section{HYDROGEOLOGIC SETTING}

The Cretaceous rocks of the Edwards-Trinity aquifer system thin toward the northwest atop massive, comparatively impermeable and structurally complex pre-Cretaceous rocks. From predominately terrigenous clastic sediments in the east and fluvial-deltaic (terrestrial) deposits in the west, the rocks of early Trinitian age grade upward into supratidal evaporitic and dolomitic strata, intertidal limestone and dolostone, and shallow-marine, open-shelf, and reefal strata of late Trinitian, Fredericksburgian, and Washitan age. A thick, downfaulted remnant of mostly open-marine strata of Eaglefordian through Navarroan age composes a small, southeastern part of the aquifer system.

The correlation chart on table 1 shows the relation between stratigraphic units in the study area and the hydrogeologic units of the Edwards-Trinity aquifer system. The correlation chart combines pertinent chronostratigraphic and lithostratigraphic nomenclature with aquifer terminology recommended in the Texas Water Plan (Texas Water Development Board, 1990). The stratigraphic nomenclature was selected from the results of stratigraphic research by colleges and univer- sities, agencies of local and Federal governments, and industry.

\section{Stratigraphy}

\section{Trinity Group}

The stratigraphy of the Trinity Group in the study area was synthesized for table 1 from several publications. The correlation of the Trinity rock units is based primarily on descriptions by Forgotson (1956), Lozo and Stricklin (1956, fig. 4), Brand and Deford (1958, fig. 2), Loucks (1977, fig. 4), and Smith and Brown (1983, fig. 3). The lateral and vertical distributions of the Trinity rock units are summarized in figures 6 and 7 , respectively.

Sediments in the Trinity outcrop between the top of Paleozoic rocks and the base of the Glen Rose Limestone were originally called the Travis Peak Formation (Taff, 1892; Hill and Vaughan, 1898; and Hill, 1901). After finding key disconformities and an additional shale unit within the Travis Peak sequence, Lozo and Stricklin (1956) raised each member of the original Travis Peak Formation to formational rank. Lozo and Stricklin (1956, p. 68) recommended that Travis Peak nomenclature be "*** deleted from modern stratigraphic terminology or reserved for use by laymen." However, in recognition of usage that continues locally, the term "Travis Peak equivalent" is applied in this report to the outcrop and shallow subcrop of Trinity strata in the Hill Country, to represent the combined Sycamore Sand, Hammett Shale, Cow Creek Limestone, and Hensel Sand (table 1).

The Pearsall Formation was defined by Imlay $(1945$, p. 1,441$)$ to include sediments above the Sligo Formation and below the Glen Rose Limestone that represent $" * * *$ the subsurface equivalents of the Travis Peak formation of the outcrop." The Pearsall Formation is applied in this report to the subcrop of Trinity strata in the Balcones fault zone, where it contains the Pine Island Shale, Cow Creek Limestone, and Bexar Shale Members and to the south-central part of the Edwards Plateau (southeastern Edwards County; fig. 6), where the formation is not differentiated into members (table 1).

The Hosston Formation typically is a siliciclastic siltstone and sandstone in updip areas and a dolomitic mudstone and grainstone in downdip areas. The downdip dolomitic sediments grade upward into supratidal 
evaporites and intertidal limestone and dolostone of the Sligo Formation (Bebout and others, 1981). From a shallow-marine carbonate lithofacies in downdip areas, the Sligo Formation grades updip, toward the Llano uplift (fig. 6), into the terrigenous clastic lithology of the Hosston Formation (fig. 7). Farther updip, the Hosston Formation grades into the Sycamore Sand (Lozo and Stricklin, 1956) of the outcrop area. The Sycamore Sand is a clastic unit composed predominately of quartzose sand and gravel, with some feldspathic and dolomitic detritus that was eroded from the Llano uplift and deposited on its flanks by aggrading streams (Amsbury, 1974, p. 6).

The Hammett Shale (Lozo and Stricklin, 1956) in the Hill Country has the same stratigraphic position as the genetically similar Pine Island Shale Member of the Pearsall Formation (Forgotson, 1956) in the Balcones fault zone (table 1); the different nomenclature reflects the preferred usage in each area (Murray, 1961, p. 308-309). The Pine Island Shale Member extends eastward from the Balcones fault zone and is one of the most persistent Lower Cretaceous rock units of east Texas. The updip Hammett Shale typically is a highly burrowed mixture of clay, terrigenous silt, lime mud, silt-sized dolomite, and other carbonate particles (Amsbury, 1974). The downdip Pine Island Shale Member is primarily a gray to black calcareous shale interbedded with dense gray limestone (Forgotson, 1957). The Hammett Shale and the Pine Island Shale Member interfinger vertically with the overlying Cow Creek Limestone and Cow Creek Limestone Member, respectively (fig. 7a).

The Cow Creek Limestone (Lozo and Stricklin, 1956) is a regressive beach sequence on the southern flank of the Llano uplift (Stricklin and Smith, 1973). The lower part of the Cow Creek Limestone generally is a fine- to coarse-grained calcarenite, with large oyster fragments. The middle part is a silty calcarenite, containing carbonate concretions and fine quartz sand. The upper part is a crossbedded beach coquina, composed primarily of oyster-shell detritus with poorly sorted quartz grains and scattered chert pebbles. The updip part of the Cow Creek Limestone generally is overlain by the Hensel Sand, and the Cow Creek Limestone Member of the Pearsall Formation (Forgotson, 1956) generally is overlain by the Bexar Shale Member (fig. 7a).

The Bexar Shale Member of the Pearsall Formation (Forgotson, 1956) typically is a mixture of dark mudstone, clay, and shale. The name is derived from
Bexar County, where the unit produces a distinct pattern on electric logs (Forgotson, 1957, p. 2,347). In this report, the Bexar Shale Member applies to the gray to black calcareous shale with intermixed thin beds of dense, finely crystalline limestone present between the Cow Creek Limestone Member and the Glen Rose Limestone throughout the Balcones fault zone. The Bexar Shale Member has been interpreted as the finegrained, marine equivalent of the near-shore, terrigenous facies of the Hensel Sand (Loucks, 1977, p. 106). The Hensel Sand (Lozo and Stricklin, 1956) comprises a weakly' cemented mixture of ferruginous clay, quartz and calcareous sand (crossbedded in places), and chert and dolomite pebbles, which typically form a basal conglomerate (Inden, 1974). The clastic sediments of this time-transgressive unit weather to a distinctive nonuniform, rusty-yellow hue. The downdip part of the Hensel Sand grades northwestward into the genetically similar basal Cretaceous sand (fig. 7b). The updip Hensel Sand, on the southern flank of the Llano uplift (fig. 7a), has been interpreted as the clastic, shoreward equivalent of the Glen Rose Limestone (Stricklin and others, 1971).

The Glen Rose Limestone (Lozo and Stricklin, 1956) is a sandy, fossiliferous limestone and dolostone characterized by repetitious interbeds of calcareous marl, clay, and shale with laterally persistent stringers of gypsum and anhydrite. The (informal) lower member of the Glen Rose Limestone comprises mostly medium-thick beds of limestone, dolostone, and dolomitic limestone with diverse mollusk assemblages and local rudist reefs (Perkins, 1974). The (informal) upper member of the Glen Rose Limestone is predominately a thin- to medium-bedded sequence of nonresistant marl alternating with resistant beds of dolostone, lime mudstone, and bioclastic limestone (Stricklin and others, 1971). The upper member generally contains one or more evaporite stringers and shows no evidence of reef formation. The alternating beds of different lithology within the Glen Rose Limestone provide an uneven resistance to erosion, resulting in a characteristic "stairstep" topography over much of its outcrop area in the Hill Country.

The calcareous, shallow-marine lithology of the Glen Rose Limestone grades northward into a quartzose clastic, terrestrial lithology characteristic of the Hensel Sand in the eastern part of the study area and the basal Cretaceous sand in the western part (fig. 6). The location of this carbonate-to-clastic facies transition, known as the Glen Rose pinchout, is approximated in 
figure 6 by a zigzag pattern between northern Blanco and southern Pecos Counties. In the southern parts of the Edwards Plateau and Trans-Pecos, the Glen Rose Limestone generally is overlain by the Maxon Sand.

The Maxon Sand (King, 1980, p. 21) predominately is a brownish, well indurated, coarse- to medium-grained, crossbedded sandstone, with lesser quantities of conglomerate, mudstone, and limestone (Butterworth, 1970, p. 4). The sandstone is composed mainly of quartz with minor quantities of feldspar and heavy (metallic) minerals eroded from Permian and Triassic rocks northwest of the study area. The constituents generally are consolidated with calcite, hematite, and kaolinite cements. The Maxon Sand forms conspicuous ledges atop the Glen Rose Limestone where these units crop out along escarpments east of the Marathon uplift in southern Pecos County (fig. 6). From Terrell County eastward, the Maxon Sand is covered by the Fort Terrett Formation.

The (informal) basal Cretaceous sand (Smith and Brown, 1983) is the only Trinity rock unit in the northern part of the study area (table 1, fig. 6). The basal Cretaceous sand underlies the updip wedge of Glen Rose Limestone in southwestern parts of the study area, where it is stratigraphically equivalent to the Hosston Formation, Hammett Shale, Cow Creek Limestone, and Hensel Sand (fig. 7b). North of the updip limit of Glen Rose Limestone, the basal Cretaceous sand underlies either the Finlay or Fort Terrett Formations of Fredericksburgian age and includes sediments equivalent to the Maxon Sand. The basal Cretaceous sand is identical to the "basement sands," "Trinity sand," and "basal Cretaceous sandstone" of previous reports and incorporates the Yearwood Formation and Cox Sandstone of Brand and Deford (1958).

The basal Cretaceous sand, largely of a fluvialdeltaic origin, generally consists of varying mixtures of sandstone, siltstone, and conglomerate. The major constituents are well-rounded fragments of quartz, chert, and feldspar derived from Permian and Triassic red beds. Calcite is the dominant cement, but dolomite, ankerite, silica, kaolinite, and hematite are prevalent cements locally (Romanak, 1988, p. 27). This diverse, areally extensive unit generally is unfossiliferous and varies vertically and laterally in color, texture, composition, and degree of cementation. The lower part of the unit generally is coarse-grained, and a fine- to mediumgrained sandstone replaces a basal conglomerate in places. The finer grained, variegated middle part of the unit is crossbedded in places and indurated locally with calcareous cement. The upper part of the unit contains small quantities of limestone and thin, calcareous shale interbeds.

\section{Fredericksburg and Washita Groups}

The stratigraphy of the Fredericksburg and Washita Groups in the study area (table 1) was modified from reports by Brand and Deford (1958), Lozo and Smith (1964), Rose (1972), and Smith and Brown (1983). The correlation chart links: (1) the Edwards Group of Rose (1972) in the northeastern part of the Balcones fault zone and eastern part of the Edwards Plateau; (2) the Devils River, West Nueces, McKnight, and Salmon Peak Formations of Lozo and Smith (1964) in the southwestern part of the Balcones fault zone and south-central part of the Edwards Plateau; (3) the Finlay and Boracho Formations of Brand and Deford (1958) in the northwestern part of the TransPecos and western part of the Edwards Plateau; and (4) the Fort Terrett and Fort Lancaster Formations of Smith and Brown (1983) in the southeastern part of the Trans-Pecos and north-central part of the Edwards Plateau. The lateral and vertical distributions of the Fredericksburg and lower Washita rocks are summarized in figures 9 and 10, respectively.

The Fredericksburg Group and lower part of the Washita Group are superseded in the northeastern part of the Balcones fault zone and eastern part of the Edwards Plateau by the Edwards Group of Rose (1972). In the northeastern part of the Balcones fault zone, the Edwards Group consists of the Kainer and Person Formations (fig. 9). In the eastern part of the Edwards Plateau, the Edwards Group consists of the Fort Terrett and Segovia Formations.

Across the western part of the Balcones fault zone, the southwestern part of the Hill Country, and the southern part of the Edwards Plateau, the Fort Lancaster, Fort Terrett, Kainer, Person, and Segovia Formations lose their identities against a narrow, semioval carbonate bank that is known as the Devils River trend (figs. 5, 10b). The Devils River trend wraps around the northern part of the Maverick basin (Winter, 1962), which also is bounded by the Stuart City reef trend on the south and by the San Marcos arch on the east. The Devils River trend, represented stratigraphically by the Devils River Formation (Miller, 1984), is a composite of dolostone, fossiliferous limestone, and reefal debris (Lozo and Smith, 1964, p. 290-296). The lower part of the Devils River Formation is stratigraphically 
continuous with lower, dolomitic parts of the Fort Terrett and Kainer Formations. However, because the Devils River Formation is relatively homogeneous from top to bottom, it is impractical to subdivide this formation stratigraphically except to recognize informally the lower (dolomitic) and upper (limestone) parts.

The Fredericksburg and lower Washita units of the Maverick basin (Lozo and Smith, 1964) are the West Nueces, McKnight, and Salmon Peak Formations. The West Nueces Formation is a transgressive lithofacies that closely resembles the nodular, shellfragment limestone at the base of the Fort Terrett Formation and in lower parts of the Devils River Formation (Smith, 1979, p. 15). According to Maclay and Small (1983, p. 132), the McKnight Formation is a predominately euxinic deposit that $" * * *$ grades upward from thin-bedded carbonate mudstones to petroliferous shales and evaporites and terminates in a layer of pelleted grainstones." The Salmon Peak Formation (Humphreys, 1984) predominately is a dense, thickbedded, deep-water mudstone that grades upward to a crossbedded, rudist-shell grainstone (Smith, 1979, p. 16).

Smith and Brown (1983) extended the Fort Terrett Formation (Rose, 1972) to include Fredericksburg strata in the central and western parts of the Edwards Plateau and in most of eastern Pecos and Terrell Counties of the Trans-Pecos (fig. 9). The Fort Terrett Formation exhibits strong lateral continuity, featuring a basal transgressive unit overlain by a distinctive burrowed zone, which is in turn overlain by thin- to mediumbedded bioclastic limestone and dolomitic strata. Although the effects of dolomitization and neomorphic alteration within the Fort Terrett Formation are prevalent in the eastern part of the Edwards Plateau (Rose, 1972, p. 29-46), these effects are much less common in the western part. Interbedded gypsum of the "Kirschberg evaporite zone," or a collapse breccia resulting from dissolution of the gypsum, is most common in the northeastern part of the Edwards Plateau.

The Fort Terrett Formation grades into the Finlay Formation near the western limits of the study area (figs. 9, 10a), where the Finlay Formation (Brand and Deford, 1958) unconformably overlies the basal Cretaceous sand of Trinitian age. The Finlay Formation is composed mostly of gray, massive to thick-bedded, cherty and marly limestone, with interbeds of gray to brown quartz sandstone and shale near the base and thin- to thick-bedded fossiliferous limestone near the top (Reaser and Malott, 1985). The Fort Terrett Formation grades southward (figs. 9, 10c), through the Big Bend area of Texas, into the Telephone Canyon and Del Carmen Formations of northern Mexico (Smith, 1970).

The Boracho Formation, which unconformably overlies the Finlay Formation, includes all the Fredericksburg and Washita strata between the Finlay Formation and the Del Rio Clay, or the Buda Limestone where the Del Rio Clay is absent. The Boracho Formation (Brand and Deford, 1958) characteristically is limestone and marl, with the exception of the basal part, which predominately is thinly laminated, yellowish shale. This shale unit weathers to a distinctive slope-forming horizon characteristic of basal Washita strata throughout the Edwards Plateau.

The Fort Lancaster Formation (Smith and Brown, 1983), composed of uppermost Fredericksburg and lowermost Washita strata in the north-central part of the Edwards Plateau and eastern part of the TransPecos, is equivalent to the Segovia Formation on the east and the Boracho Formation on the west (figs. 9, 10a). The Fort Lancaster Formation was deposited mostly in open shallow-marine to open-shelf environments (Scott and Kidson, 1977, p. 174) on the southwestern flank of the central Texas platform in water that deepened toward the Fort Stockton basin (fig. 5). Relatively thick-bedded, rudist-bearing limestone helps distinguish eastern parts of the Fort Lancaster Formation from the generally thinner-bedded, dolostone and dolomitic limestone of the Segovia Formation that formed concurrently in intertidal and restricted shallow-marine environments atop the central Texas platform. The Fort Lancaster Formation thickens toward the west and south and shows a decreasing density of rudists and miliolid and shell-fragment grainstones toward the west and north, with an increasing incidence of ammonites, pelecypods, and marly sediments (C.I. Smith, University of Texas at Arlington, oral commun., 1989). The Fort Lancaster Formation grades southward (figs. $9,10 \mathrm{c}$ ), through the Big Bend area of Texas, into the Sue Peaks and Santa Elena Formations of northern Mexico (Smith, 1970).

The marly, nodular limestone that composes basal parts of the Fort Lancaster and Sue Peaks Formations erodes to a distinctive grass-covered slope over much of the Edwards Plateau and Trans-Pecos (Smith and Brown, 1983, p. 19). The characteristic outcrop of this ammonite-bearing horizon has helped geologists map the Fredericksburgian-Washitan boundary in the field for more than 100 years. 
The Del Rio Clay on the San Marcos arch consists of dark bluish-gray, calcareous, pyritic bentonitic clay and shale, with scattered mollusk fragments and pelagic foraminifera (Rose, 1972, p. 27). In the eastern part of the Edwards Plateau, the Del Rio Clay is a yellowish-brown, soft calcareous clay containing thin, reddish-brown silty streaks and coquinoid lenses of small oysters (Rose, 1972, p. 43). In the Trans-Pecos and western part of the Edwards Plateau, the unit is fossiliferous (with some ammonites) and consists mostly of interbedded calcareous and siliceous flagstones and marly limestone (Adkins, 1933, p. 388-396). The Del Rio Limestone almost everywhere contains pyrite that, upon weathering to limonite (iron oxide), renders a characteristic yellowish-brown tint to the outcrop. From a maximum thickness of about $170 \mathrm{ft}$ near the town of Del Rio (fig. 9), the formation thins in all directions. Only thin, scattered remnants exist in the western part of the Edwards Plateau.

The Buda Limestone on the San Marcos arch is a light gray, porcellaneous limestone with pelagic foraminifera, fragile mollusk fragments, and microspherulites (Rose, 1972, p. 27). In the eastern part of the Edwards Plateau, this open-shelf limestone consists of nodular micrite, mollusk-fragment biomicrite, and marly interbeds (Rose, 1972, p. 43). In the TransPecos, where the unit typically is exposed atop mesas as a light gray to white caprock, the Buda Limestone is slightly argillaceous, locally crossbedded, and extremely hard (Brand and Deford, 1958, p. 385). Fractured surfaces of Buda Limestone generally are hackly or conchoidal and weathered surfaces typically are nodular.

The Del Rio Clay and Buda Limestone of Washitan age (Comanchean Series) are overlain in the Balcones fault zone by Eagle Ford, Austin, Taylor, and Navarro sediments of the Gulfian Series (table 1). The Eagle Ford-Navarro rock sequence is thickest in the Balcones fault zone where it forms the bulk of the Navarro-Del Rio confining unit, which typically is thicker than 1,000 ft (table 2). The Eagle Ford, Austin, Taylor, and Navarro Groups consist primarily of interbedded shale, siltstone, limestone, chalk, and marl (University of Texas, Bureau of Economic Geology, 1974a, 1983).

\section{Regional Aquifers and Confining Units}

The Cretaceous strata in the study area are divided into three major aquifers and two major confining units (table 1). These divisions are based on regional contrasts in hydraulic conductivity that determine the relative capacity of the different rock units to transmit ground water over large areas. The hydraulic conductivity of the strata mostly was inferred from aquifer-test and specific-capacity data, and an inherent relation between stratigraphy and hydraulic conductivity. The aquifer-test and specific-capacity data were obtained mainly from Walker (1979), Rees and Buckner (1980), Ashworth (1983), Baker and others (1986), and Maclay and Small (1986).

The relation between stratigraphy and hydraulic conductivity results from the fact that the stratigraphy reflects the lithology and distribution of the various rock units or formations. Each formation is the result of a relatively consistent set of depositional, tectonic, and diagenetic conditions; hydraulic conductivity evolved from these conditions. Therefore, the hydraulic conductivity of strata for which hydraulic data were not available was inferred from the relation between stratigraphy and hydraulic conductivity where that relation was known.

The regional aquifers are composed of strata that are permeable mainly as the result of fractures, joint cavities, and porosity caused by the dissolution of evaporites and unstable carbonate constituents. The confining units comprise comparatively impermeable strata that are continuous over more than $100 \mathrm{mi}^{2}$ and affect regional patterns of ground-water flow and storeage. The confining units are mostly calcareous mudstone, siltstone, and shale of low-energy terrigenous and open-shelf depositional environments. Because of the regional scope of the RASA study and the need to generalize from site-specific data, the aquifers include some confining strata, and the confining units contain some strata permeable enough to supply small amounts of water to a few wells in limited areas.

From east to west (fig. 2), the three major aquifers are the Edwards aquifer in the Balcones fault zone, the Trinity aquifer in the Balcones fault zone and Hill Country, and the Edwards-Trinity aquifer in the Edwards Plateau and Trans-Pecos. The Navarro-Del Rio confining unit covers about 70 percent of the Balcones fault zone, and the Hammett confining unit subcrops beneath about 80 percent of the Hill Country and less than 10 percent of the Edwards Plateau. 
The Hammett confining unit is restricted to the Hill Country and southeastern margin of the Edwards Plateau, where structural displacement of the hydraulically tight Hammett Shale has been minor (Barker and Ardis, in press, pls. 3, 7, and 8). Vertical displacement of the Pine Island Shale Member of the Pearsall Formation prevents the downdip-equivalent of the Hammett Shale from being an effective regional confining unit within the Balcones fault zone.

In contrast, the Navarro-Del Rio confining unit is restricted to the Balcones fault zone (Barker and Ardis, in press, pls. 3, 7). From top to bottom, this confining unit includes the Navarro Group, Taylor Group, Austin Group, Eagle Ford Group, Buda Limestone, and Del Rio Clay. Although vertically displaced within the Balcones fault zone, the combined thickness (approximately $1,500 \mathrm{ft}$ ) of these rock units typically is more than 10 times the maximum thickness of the Pine Island Shale Member (130 ft; table 2). Despite the fault displacement, the Navarro-Del Rio confining unit is comparatively continuous within the Balcones fault zone, where it is effective as a confining medium atop the Edwards aquifer.

Thin, scattered remnants of the Del Rio Clay and Buda Limestone, plus minor outcrops of Gulf strata, overlie parts of the Edwards Plateau and Trans-Pecos. None of these rocks is known to yield water to wells. However, the rocks are not regarded as confining units west of the Balcones fault zone because none is directly underlain by saturated rock.

\section{Ground-Water Hydrology}

From a minimum thickness of less than $1,000 \mathrm{ft}$ in the outcrop area, the wedge of Cretaceous sediments thickens downdip to more than $10,000 \mathrm{ft}$ near the ancestral shelf edge (McFarlan, 1977, p. 5). The Edwards-Trinity aquifer system is in the updip, western half of this wedge where terrigenous clastic and terrestrial sediments of early Trinitian age grade upward and gulfward into marine carbonate rocks of late Trinitian, Fredericksburgian, and Washitan age. The groundwater conditions in these rocks are summarized below for each of the four geographic subareas beginning with the Balcones fault zone, the most transmissive part of the study area.

\section{Balcones Fault Zone}

The Edwards aquifer in the Balcones fault zone (fig. 3) is one of the most productive reservoirs of potable ground water in the Nation. The aquifer exists within intensively fractured and extensively leached Washita and Fredericksburg strata (table 1); the hydraulic conductivity of the underlying Trinity strata is negligible by comparison. The U.S. Environmental Protection Agency has declared the Edwards aquifer a sole-source aquifer in the San Antonio area, where it serves the domestic, public-supply, industrial, and agricultural needs of more than 1 million people. The economy of Medina and Uvalde Counties, southwest of San Antonio, primarily is based on farming and ranching activities that depend on water from the Edwards aquifer. Toward the northeast, between San Antonio and Austin, the Edwards aquifer discharges to Barton, Comal, and San Marcos Springs (fig. 3), which help support the local recreation and tourism industries.

Ground-water conditions in the Edwards aquifer have evolved from tectonic and diagenetic events superimposed upon depositional products of the San Marcos arch (Rose, 1972), Devils River trend (Lozo and Smith, 1964), and Maverick basin (Winter, 1962). The part of the Edwards aquifer that formed on the San Marcos arch and in the Devils River trend extends from the Colorado River through eastern Uvalde County (fig. 2). The part of the Edwards aquifer that formed in the Maverick basin extends from west-central Uvalde County through east-central Kinney County. This section of the report discusses ground-water conditions in the Edwards aquifer east of central Uvalde County (figs. 2, 5, and 9) in rocks that formed on the San Marcos arch (Georgetown, Person, and Kainer Formations) and in the Devils River Trend (Devils River Formation). Ground-water conditions in equivalent rocks that formed in the Maverick basin (Salmon Peak, McKnight, and West Nueces Formations) are discussed in the "Edwards Plateau" section, as the hydraulic conditions in west-central Uvalde through east-central Kinney Counties (at the westernmost end of the Balcones fault zone) are most like those in the EdwardsTrinity aquifer in the southern part of the Edwards Plateau.

The Edwards aquifer is hydraulically unconfined in the outcrop area of the Georgetown, Person, and Kainer Formations and in the outcrop areas of the Devils River, Salmon Peak, McKnight, and West Nueces Formations across parts of Kinney, Uvalde, and 
Medina Counties (figs. 2, 9). The Edwards aquifer is confined in downdip areas beneath the Navarro-Del Rio confining unit. The confined part of the aquifer is bound on its downdip (gulfward) side by a freshwater/ saline-water transition zone of brackish water. The concentrations of dissolved solids downdip of the transition zone exceed 1,000 $\mathrm{mg} / \mathrm{L}$ (Maclay and others, 1980, p. 13) and rapidly increase in a gulfward direction to more than $250,000 \mathrm{mg} / \mathrm{L}$ (Maclay and Land, 1988, p. A12) near the Stuart City reef trend (fig. 5). The concentration of dissolved solids in the Edwards aquifer updip of the transition zone ranges from about 250 to $300 \mathrm{mg} / \mathrm{L}$ (Pavlicek and others, 1987, p. 3).

Ellis (1986, p. 101) attributes diagenetic differences between rocks of the saline-water zone and those of the Edwards aquifer to the effects of vastly different pore-water chemistry since the Miocene Epoch, when the majority of the normal (down-to-the-southeast) faulting in the Balcones fault zone probably occurred. Although the saline-water zone is saturated with respect to calcite, dolomite, gypsum, celestite, strontianite, and fluorite, the Edwards aquifer is saturated only with respect to calcite (Pearson and Rettman, 1976, p. 19). The rocks of the highly permeable Edwards aquifer are calcitic, typically recrystallized to coarse microspar and pseudospar, and extensively dedolomitized. The nearly impermeable saline-water zone mostly consists of dolomitic rocks containing unoxidized organic material, including petroleum and accessory minerals such as pyrite, gypsum, and celestite (Maclay and Small, 1986, p. 28). The negligible hydraulic conductivity of the saline-water zone results from minimal connection between interparticle pores caused by a diagenetic history dominated by cementation in a saline-water environment.

The extraordinarily large values of hydraulic conductivity in the Edwards aquifer result from the freshwater diagenesis of intensively fractured carbonate rocks. After large-scale normal faulting fractured the terrain and increased hydraulic gradients, large quantities of meteoric water entered previously buried strata and initiated the evolution of a dynamic groundwater-flow system (Abbott, 1975). The preferential leaching of evaporites and soluble minerals, fossil parts, and burrow fillings has provided a honeycombed, or "Swiss cheese," appearance to much of the outcrop area. Much of the subcrop area is riddled with joint cavities and solution channels that formed as fractures and bedding planes widened through dissolution and erosional unloading.
Ground-water flow in the Edwards aquifer largely is controlled by an anisotropic pattern of hydraulic conductivity. The anisotropy primarily results from barrier faults, which displace rocks vertically such that permeable strata are juxtaposed against impermeable strata (Barker and Ardis, in press, pls. 2, 6 , and 7), blocking or impairing transmissivity in directions normal to the faults. The dominant direction of transmissivity approximates a N. $60^{\circ}$ E. trend, along which transmissivity values compare with those normal to the trend by ratios ranging from 1:0 to 1:1 (Maclay and Land, 1988, fig. 20), depending upon the extent of aquifer displacement (Small, 1986). Transmissivity values along the principal direction of ground-water flow range from about 200,000 to about $2,000,000 \mathrm{ft}^{2} / \mathrm{d}$ (Maclay and Small, 1986, p. 61). The anisotropy is so dominant in the subcrop of the Edwards aquifer in Bexar County (Arnow, 1963, p. 2931 ) that most of the confined ground-water flow is nearly parallel to generalized equipotential lines on regional potentiometric maps of the San Antonio area (Maclay and Small, 1986, fig. 23).

The barrier faults generally block southeastward flow in the Edwards aquifer and divert ground water toward the northeast along flowpaths aligned with the fault zone (Arnow, 1963). In some places, a secondary network of transverse faults obstructs the major northeast-trending flowpaths, imposing internal boundaries that further divert or compartmentalize the flow system (Maclay and Small, 1993, p. 135-145). As a result, local patterns of ground-water flow can be extremely complex, making predictions about future responses to prolonged drought or additional pumping difficult to determine for specific sites.

The Edwards aquifer primarily is recharged by the (1) discharge of streams draining the Hill Country where they flow onto the highly permeable outcrop of the Edwards Group and Devils River Formation; (2) infiltration of precipitation in the outcrop area; (3) subsurface inflow across the updip margin of the Balcones fault zone, where the Trinity aquifer is laterally adjacent to downfaulted Edwards strata (Barker and Ardis, in press, pl. 3); and (4) diffuse upward leakage from the underlying Trinity aquifer. Recharge rates vary considerably with time, depending upon antecedent conditions and the frequency and intensity of precipitation. Although the actual rates of recharge cannot be measured, estimates of recharge routinely are made for water management purposes. 
Estimates of total recharge to the Edwards aquifer (Nalley, 1989, table 2) range from less than 50,000 acre-ft in 1956 to more than 2,000,000 acre-ft in 1987 . (Precipitation was about 50 percent less than the longterm average in 1956, and was about 20 percent greater than the average in 1987.) Recharge probably has averaged about 675,000 acre-ft/yr since the mid-1930's, not including water entering laterally from the Trinity aquifer in the Hill Country. The quantity of water entering laterally from the Hill Country is unknown; however, a preliminary estimate (assuming an average hydraulic gradient of $20 \mathrm{ft} / \mathrm{mi}$ and an average transmissivity of $5,000 \mathrm{ft}^{2} / \mathrm{d}$ ) indicates that this inflow could total more than 100,000 acre-ft/yr. The quantity of diffuse upward leakage from the Trinity aquifer also is unknown; however, the preliminary results of computer simulation (E.L. Kuniansky, U.S. Geological Survey, written commun., 1992) indicate a long-term average rate of about 10,000 acre-ft/yr.

From upgradient parts of the recharge area, ground water generally flows downdip in a southward or southeastward direction. This water typically is diverted northeastward along joint cavities and solution channels that have developed upgradient of the barrier faults. Most ground-water discharge occurs as either: (1) springflow; (2) withdrawals through irrigation, public-supply, and industrial wells; (3) leakage to the Colorado River; or (4) diffuse upward leakage to Upper Cretaceous strata.

Springflow has averaged about 400,000 acre$\mathrm{ft} / \mathrm{yr}$ since the mid-1930's (Nalley, 1989, table 3; Slade and others, 1986, p. 69). Well withdrawals have steadily increased from about 100,000 acre-ft/yr during the 1930's to about 470,000 acre-ft/yr during the 1980's (Nalley, 1989, table 3). The rates of leakage to the Colorado River and Upper Cretaceous strata are unknown; however, they are considerably smaller than the rates of springflow and well withdrawal.

The major center of public-supply pumpage is San Antonio, where water levels in an observation well open to confined parts of the aquifer have varied between $612.5 \mathrm{ft}$ above sea level in 1956 and $703.2 \mathrm{ft}$ above sea level in 1992 (G.M. Nalley, U.S. Geological Survey, written commun., 1992). Despite public concern about occasional periods of flooding or drought, long-term hydrographs for the San Antonio area indicate no net rise or decline in water levels over the last 85 years (R.W. Maclay, U.S. Geological Survey, written commun., 1990).

\section{Hill Country}

The Trinity aquifer, in rocks of the Trinity Group (table 1), dominates the ground-water hydrology of the Hill Country (fig. 3). As a result of the Balcones faulting and subsequent erosion, most of the Fredericksburg and practically all of the Washita strata have been removed from the Hill Country. However, a few domestic- and stock-supply wells are completed in the Fort Terrett Formation in interstream areas of northwestern Bandera, northern Kendall, and eastern Kerr Counties; likewise, the Devils River Formation contributes locally to the water supply in southern Real and northern Uvalde Counties.

The Trinity aquifer in the Hill Country is composed of three relatively permeable zones that are separated vertically by two relatively impermeable intervals. The upper Trinity permeable zone comprises the upper member of the Glen Rose Limestone. The middle Trinity permeable zone comprises the lower member of the Glen Rose Limestone, the Hensel Sand, and the Cow Creek Limestone. The lower Trinity permeable zone comprises the Sycamore Sand (updip) and the Sligo and Hosston Formations.

The upper Trinity permeable zone is separated from the middle Trinity permeable zone by thin- to medium-bedded, hydraulically tight sediments within the upper and middle parts of the Glen Rose Limestone. These nearly impermeable intervals (Ashworth, 1983, p. 33) typically are composed of "*** laterally continuous, alternating resistant and nonresistant beds of blue shale, nodular marl, and impure fossiliferous limestone." Because of their relatively high stratigraphic position, these beds generally are above the regional potentiometric surface (Kuniansky, 1990) of the topographically rugged Hill Country.

The lower Trinity permeable zone is separated from the middle Trinity by the Hammett (Shale) confining unit. Because of its depth below land surface and fine-grained composition, the Hammett Shale is areally continuous and relatively impermeable throughout most of the Hill Country, except where it has been disrupted by faults or breached by the Pedernales River and Cypress Creek drainages (Stricklin and Amsbury, 1974, pl. 6). Displacement of the downdip-equivalent Pine Island Shale Member by high-angle normal faults disrupts the confining effect of the shale in the Balcones fault zone; therefore, the Hammett confining unit is limited to the Hill Country and the southeastern edge of the Edwards Plateau (fig. 2; table 1). 
The hydrology of the Hill Country varies greatly in response to diverse geologic conditions and wideranging topographic effects. Although ground water in the deeper strata generally is confined, unconfined conditions prevail within a few hundred feet of the surface. The leaching of evaporites and unstable carbonate constituents has enhanced the hydraulic conductivity of some upgradient, outcrop (recharge) areas; however, the precipitation of stable minerals has diminished the hydraulic conductivity of most downgradient, subcrop areas. The transmissivity of the Trinity aquifer is highly variable because the saturated thickness varies with both hydraulic head (Bush and others, 1993) and the altitude of underlying pre-Cretaceous rocks (Barker and Ardis, 1992).

The quartzose clastic deposits that dominate the Sycamore Sand, updip parts of the Hensel Sand, and basal parts of the Hosston Formation are some of the most permeable sediments in the Hill Country. Outcrop surfaces of the Cow Creek Limestone characteristically are riddled with moldic porosity and are highly permeable; most of the outcrop area is particularly receptive to recharge. Although the initial hydraulic conductivity of the Cow Creek Limestone was large because it resulted from a high-energy (beach) depositional environment, the hydraulic conductivity today is comparatively small, except near the outcrop, because most primary voids are filled with calcitic cement. Lower parts of the Glen Rose Limestone are highly permeable, especially in the outcrop and shallow subcrop areas, where the unit is locally karstic as the result of meteoric diagenesis. Sinkholes atop the Glen Rose Limestone in western parts of the Hill Country intercept surface water and provide passageways for substantial quantities of recharge to the Trinity aquifer (Ashworth, 1983, p. 10).

Vertical differences in hydraulic head are common within the Trinity aquifer. The greatest and most widespread head differences generally occur across downdip parts of the Hammett Shale, an areally extensive confining unit that attains a thickness of about 40 to $80 \mathrm{ft}$ over most of the Hill Country (Amsbury, 1974, p. 18). Ashworth (1983, figs. 16-18) reports that differences in hydraulic head across the Hammett Shale exceed $100 \mathrm{ft}$ over parts of eastern Bandera, Kendall, and eastern Kerr Counties. Water levels in the Glen Rose Limestone near the southeastern corner of Edwards County are more than $200 \mathrm{ft}$ higher than those in the underlying Hosston Formation. Differences in hydraulic head above the Hammett Shale generally are caused by strongly cemented (but commonly thin) interbeds of claystone, marl, and shale that are interspersed throughout the upper and middle permeable zones of the Trinity aquifer, but most commonly within the Glen Rose Limestone.

The strongly cemented, relatively impermeable interbeds in upper and middle parts of the Glen Rose Limestone generally impede the downward percolation of precipitation. Meteoric water that infiltrates the interstream areas circulates laterally above the dense, hydraulically tight interbeds more readily than it percolates vertically through them. Shallow zones of perched ground water commonly are present above the base level of adjacent streams. Ground water discharges from springs and seeps atop the interbeds where they are exposed on the hillsides in the Hill Country. Thus, instead of percolating to the regional flow system, much of the shallow ground water in interstream segments of the Hill Country discharges to perennial streams that drain the area (fig. 3).

Perennial streams in the Hill Country gain water as they intercept springflow and base flow from the upper and middle permeable zones of the Trinity aquifer (Ashworth, 1983, p. 47). Streams that gain water in the Hill Country typically lose all of their discharge to the downstream recharge area of the Edwards aquifer; this generally occurs where the streams cross major faults and flow onto the relatively permeable outcrop of the Edwards Group in the Balcones fault zone.

In addition to discharging as springflow and base flow from the upper and middle permeable zones, water discharges from the Trinity aquifer through well withdrawals and lateral, subsurface inflow to the Balcones fault zone. Discharge from the lower Trinity permeable zone occurs primarily through water wells and diffuse upward leakage to the middle Trinity permeable zone. Much of the diffuse upward leakage eventually discharges laterally to the Balcones fault zone. During the mid-1970s, well withdrawals are estimated to have totaled between 10,000 to 15,000 acre-ft/yr (Lurry and Pavlicek, 1991, table 1). The Trinity aquifer is recharged, in order of importance, by the (1) lateral inflow of ground water from the Edwards Plateau, (2) infiltration of precipitation on the outcrop area, and (3) surface-water leakage from shallow, tributary streams in upland areas.

Long-term hydrographs of water levels measured from observation wells in the Hill Country indicate that water levels can vary greatly over short periods. Between winter highs and summer lows, water 
levels typically vary $50 \mathrm{ft}$ or more. The seasonal variances are most striking in wells less than about $250 \mathrm{ft}$ deep. Because transmissivity values generally are small in the Hill Country and the demand for pumping is strongly dependent on weather conditions, the Trinity aquifer in this area is more susceptible to the effects of drought than the Edwards aquifer in the Balcones fault zone.

Transmissivity values derived from pumping tests and specific-capacity data (Ashworth, 1983, p. 55-155) range from less than $1,000 \mathrm{ft}^{2} / \mathrm{d}$ to about $50,000 \mathrm{ft}^{2} / \mathrm{d}$ for the Trinity aquifer in the Hill Country. Transmissivity values appear to average about 5,000 $\mathrm{ft}^{2} / \mathrm{d}$, according to the results of a regional groundwater-flow model (E.L. Kuniansky, U.S. Geological Survey, written commun., 1990).

\section{Edwards Piateau}

The Edwards-Trinity aquifer in the Edwards Plateau (fig. 3) includes all the Fredericksburg and Trinity rocks, plus all Washita rocks below the Del Rio Clay or Buda Limestone (where the Del Rio Clay is absent) or land surface. None of the rock units is uniformly permeable throughout the area. However, the rocks are combined regionally into one aquifer because no parts are substantially more or less permeable than the rest.

The Washita and Fredericksburg rocks are the primary water-producing strata throughout more than two-thirds of the Edwards Plateau. Except where the Washita and Fredericksburg rocks are absent or minimally saturated, the hydrologic characteristics of the Trinity Group largely are untested. Water wells generally do not penetrate below Fredericksburg strata, unless the Washita and Fredericksburg rocks have failed to provide sufficient water. Because the Trinity rocks thin to a negligible thickness near the Llano uplift (fig. 6) and the regional potentiometric surface (Kuniansky, 1990) is below the base of Washita rocks in northern parts of the Plateau, the Fredericksburg rocks generally are the most reliable sources of potable water in the area.

The Washita and Fredericksburg rocks are the principal water-producing zones south of northern Concho, Irion, Reagan, Tom Green, and Upton Counties (fig. 2), except where they have been breached by erosion along the valleys of the Concho, Guadalupe, Llano, Pecos, Pedernales, and San Saba Rivers (fig. 3). In these topographically low areas, the Glen Rose Limestone, Hensel Sand, and basal Cretaceous sand augment the valley alluvium as the main sources of ground water. Although the Washita rocks are used only minimally for water supply in the northern Edwards Plateau, they become more important as they thicken and become increasingly saturated toward the south. Where the Fort Lancaster Formation (west) and Segovia Formation (east) occupy the highest elevations on the Edwards Plateau, they generally are unsaturated, minimally saturated, or contain only perched water. However, the Fort Lancaster and Segovia Formations, in addition to the Devils River and Salmon Peak Formations (in the Devils River trend and Maverick basin, respectively), are important water-producing units in parts of Edwards, Kinney, and Val Verde Counties.

The Salmon Peak Formation is "moderately to very permeable" near the top (Maclay and Small, 1986, p. 18). The lower part of the Salmon Peak Formation is "almost impermeable," except where fractured. The McKnight Formation locally contains permeable pockets of leached evaporites, but mostly it is considered to have "little permeability." Although the upper part of the West Nueces Formation is "moderately permeable," the lower part is "almost impermeable."

The Devils River Formation is "very permeable and porous," especially in middle and upper parts of the unit that contain collapse breccia or vuggy zones of leached rudists (Maclay and Small, 1986). The upper and middle parts of the formation compose the principal water-producing zone in southern Edwards County and in central Val Verde County. The Devils River Formation supplies large quantities of irrigation water in western parts of the Balcones fault zone, in Medina and Uvalde Counties, where this unit is considered a major aquifer (Maclay and Small, 1986, table 1).

The Fort Terrett Formation provides most of the ground water pumped in the Edwards Plateau. The "burrowed zone" (table 1), near the base of the formation, may be the most permeable part of the Edwards Group outside the fractured terrain of the Balcones fault zone. The permeable nature of the burrowed zone results from the preferential leaching of burrow fillings, leaving a honeycombed pattern of porosity in the remaining rock (Rose, 1972, p. 34). The overlying "Kirschberg evaporite zone" (table 1) also is highly permeable, especially where it is brecciated as the result of post-depositional leaching and structural collapse. Although the zones of Kirschberg breccia west of the Balcones fault zone are mostly unsaturated, the breccia enhances recharge in eastern parts of the 
Edwards Plateau by increasing the infiltration rates of precipitation.

Except in a few areas with shallow alluvial aquifers, the basal Cretaceous sand of Trinitian age is the most important water-producing unit in Ector, Glasscock, Midland, Sterling, and Upton Counties and along the Pecos River valley in Crockett County (fig. 6). The basal Cretaceous sand is about as important as the Fredericksburg rocks for ground water in southern Irion, southeastern Reagan, and southern Tom Green Counties. Very few water wells are deep enough to penetrate the basal Cretaceous sand over most of Crockett, Edwards, Schleicher, Sutton, and Val Verde Counties.

In the southeastern part of the Edwards Plateau (northwestern Bandera, eastern Edwards, western Kerr, and northern Real Counties), the Trinity units most likely to contain potable ground water are the Hensel Sand, lower member of the Glen Rose Limestone, and Cow Creek Limestone. The hydraulic characteristics of the much deeper Pearsall (undivided), Sligo, and Hosston Formations mostly are unknown. However, the lower Trinity units in this area generally are more than $750 \mathrm{ft}$ below land surface. Because ground water at this depth is perhaps completely isolated from freshwater recharge, it typically is highly mineralized (Walker, 1979, p. 93-95) and may exceed the local standards for drinking water (Texas Department of Health, 1977).

The Hammett Shale, which is physically continuous and hydraulically tight over most of the Hill Country (fig. 3), grades northwestward across Edwards County into the comparatively permeable basal Cretaceous sand (figs. 6, 7b). The confining effect of the Hammett Shale diminishes west of the Hill Country, as it grades into sand and thins to a featheredge. Therefore, the Trinity strata over most of the Edwards Plateau are connected hydraulically with the overlying Fredericksburg rocks.

Hydraulic conditions in the Edwards Plateau are mostly confined or semiconfined, except in the shallowest water-transmitting zones and near the outer margins of Fredericksburg strata where the underlying Trinity sediments crop out. Although no confining unit is mappable over large areas west of the Hammett confining unit (fig. 2), the effects of many low-permeability beds accumulate with increasing depth below land surface to confine deeper parts of the Edwards-Trinity aquifer. Unconfined conditions dominate where gaining streams cut into sandy Trinity sediments along the Concho, Guadalupe, Llano, Pecos, Pedernales, and San Saba Rivers (fig. 3). From generally unconfined or semiconfined conditions in the west, the aquifer becomes progressively more confined toward the south and east in response to an increasing thickness of sediment in those directions. Observations of diurnal changes in barometric pressure, water levels that rise above the top of water-transmitting zones, and entrapped hydrogen sulfide gas prompted Walker $(1979$, p. 49$)$ to suggest that "*** water-table conditions may not be as prevalent as previously reported."

The Edwards-Trinity aquifer merges hydraulically with locally permeable Paleozoic strata around the western and southern flanks of the Llano uplift in Gillespie, Mason, and McCulloch Counties (fig. 2). Paleozoic rocks of the deeply eroded Llano uplift (fig. 4) form a subtle topographic basin where a shallow ground-water regime has developed along fractures and joint cavities. Water from the northeastern fringe of the Edwards-Trinity aquifer merges with the shallow flow regime of the Marble Falls, EllenburgerSan Saba, and Hickory aquifers (Barker and Ardis, 1992) before discharging into the Colorado River and northeastward-flowing tributaries that drain the Llano area (fig. 3).

The Edwards-Trinity aquifer directly overlies the Dockum Group of Triassic age in large parts of Crockett, Irion, Reagan, and Sterling Counties. Where middle parts of the Dockum Group are saturated and contain sufficient amounts of sand to be permeable (Barker and Ardis, 1992), they compose the Dockum aquifer (Texas Water Development Board, 1990, p. 16). Where upper parts of the Dockum Group are absent, the Dockum aquifer merges in places with the basal Cretaceous sand of the Edwards-Trinity aquifer (fig. 2, Barker and Ardis, in press, pl. 4). In such areas, the depth of ground-water circulation may increase a few hundred feet to the lower part of the Dockum Group, or-where the lower Dockum unit is absent- - to the top of Permian red beds. Water from the Dockum aquifer varies considerably in quantity and quality. However, well yields rarely exceed a few hundred gallons per minute, and the water typically contains high concentrations of sodium, sulfate, and chloride (Ashworth and Christian, 1989), which may exceed the local standards for drinking water (Texas Department of Health, 1977).

The Edwards-Trinity aquifer pinches out below the Ogallala Formation of Tertiary age along the northwestern edge of the Edwards Plateau (Barker and Ardis, in press, pl. 3) in Andrews, Glasscock, Howard, and Martin Counties (fig. 2). Coarse sand and gravel of the Ogallala Formation, which forms the High Plains 
aquifer (Gutentag and others, 1984, p. 8-13) in northwest Texas, fill erosional channels atop the basal Cretaceous sand in the northwestern part of the study area. Water discharging in a southeastward direction from the southern part of the High Plains aquifer recharges the northwestern fringe of the Edwards-Trinity aquifer.

From the northwestern part of the Edwards Plateau, water in the Edwards-Trinity aquifer generally flows southeastward under hydraulic gradients that average about $10 \mathrm{ft} / \mathrm{mi}$. Local exceptions to the regional pattern result from topographic and drainage variations and depressions in the potentiometric surface caused by pumpage. The maximum hydraulic head in the Edwards-Trinity aquifer occurs in northwestern Ector County at about 3,100 ft above sea level; the minimum hydraulic head, in southern Val Verde County, is about $2,000 \mathrm{ft}$ above sea level (Bush and others, 1993). In the southwestern part of the Edwards Plateau, ground water discharges to the Pecos River and Rio Grande. In the northeast, ground water discharges to the Colorado River and its tributaries. In the southeast, ground water discharges to headwater reaches of the Frio, Guadalupe, Medina, and Nueces Rivers (fig. 3), and as lateral, subsurface inflow to the Hill Country.

Most recharge to the Edwards-Trinity aquifer results from the infiltration of precipitation from land surface and seepage losses through streambeds of intermittent streams. Discharge from the aquifer occurs mainly through: (1) springs on the walls of streamdissected canyons on the northeastern and southeastern fringes of the Plateau; (2) base flow to gaining streams; and (3) well withdrawals. Recharge and discharge each average less than $1 \mathrm{in} / \mathrm{yr}$ over most of the Plateau, increasing from less than $0.5 \mathrm{in} / \mathrm{yr}$ in the west to more than $0.5 \mathrm{in} / \mathrm{yr}$ in the easternmost part of the area (E.L. Kuniansky, U.S. Geological Survey, written commun., 1990).

Water pumped from the Edwards-Trinity aquifer primarily is used for irrigation. Walker $(1979$, p. 76) estimated that about 72 percent of all pumpage during 1972 was for irrigation. Lurry and Pavlicek (1991, table 1) indicated that during the mid-1970's about 80 percent of the total annual pumpage from the EdwardsTrinity aquifer (about 130,000 acre-ft) was for irrigation. Irrigation pumpage from Glasscock and Midland Counties alone accounted for about one-half of all pumpage in the Edwards Plateau during 1975-76 (Lurry and Pavlicek, 1991).

Ground-water levels in the Edwards Plateau vary mostly in response to short-term fluctuations in recharge and long-term variations in discharge. Most of the fluctuations in recharge are caused by cyclic trends in precipitation, and most of the variations in discharge result from well withdrawals. Water levels have declined where the rates of recharge and natural discharge (evapotranspiration, springflow, and base flow) have not compensated for increasing rates of withdrawal.

During the last 50 years, water levels have declined more than $50 \mathrm{ft}$ in northwestern parts of the Edwards Plateau, including parts of Ector, Glasscock, Midland, Reagan, Sterling, and Schleicher Counties (Walker, 1979, p. 96-100). Data from an observation well in Reagan County indicates more than $100 \mathrm{ft}$ of decline since 1950 (Bush and others, 1993). The nearly continuous, long-term nature of water-level decline in many wells reflects the direct relation to a rapid increase in the number of irrigation wells that began about 1946 and continued through the 1960's.

Since the late 1970's, water levels in most parts of the Edwards Plateau have stabilized or begun to recover, reflecting the results of recent efforts to reduce the need for irrigation and to conserve water (J.B. Ashworth, Texas Department of Water Resources, written commun., 1991). Water-level hydrographs for central parts of the Edwards Plateau reflect a cyclic relation between recharge from precipitation and water-level change: (1) declining water levels during most of the 1960's, when precipitation was below normal; (2) rising water levels during most of the 1970's, when precipitation was above normal; and (3) declining water levels during most of the 1980's, when precipitation was below normal. Many of the highest recorded water levels during the past 30 years in Crockett, Edwards, Kimble, Schleicher, and Sutton Counties were during the middle-to-late 1970's.

Transmissivity values are relatively small in the Edwards Plateau, where the average is about 2 or 3 orders of magnitude less than those characteristic of the Balcones fault zone. Aquifer-test and specificcapacity data indicate transmissivity values of less than $5,000 \mathrm{ft}^{2} / \mathrm{d}$ for most of the Edwards Plateau (Walker 1979, p. 72-75). Exceptions are in the southern part of the Edwards Plateau, where Trinity rocks thicken southward toward the Rio Grande Embayment (fig. 5) and wells in the relatively permeable Devils River Formation yield up to $500 \mathrm{gal} / \mathrm{min}$. Preliminary results of a ground-water-flow model indicate that transmissivity values range from about 5,000 to perhaps 10,000 $\mathrm{ft}^{2} / \mathrm{d}$ over most of the Edwards and Val Verde Counties 
(E.L. Kuniansky, U.S. Geological Survey, written commun., 1990).

\section{Trans-Pecos}

The Edwards-Trinity aquifer in the Trans-Pecos (fig. 3) includes all Washita rocks below the Del Rio Clay or Buda Limestone (where the Del Rio Clay is absent) or land surface, plus all Fredericksburg and Trinity rocks. The hydrogeologic framework of Pecos, Reeves, and Terrell Counties is structurally complicated. The structural complexity results from the collapse of Cretaceous and Triassic rocks atop salt-laden Permian rocks and crustal deformation south and west of the area during Cenozoic time (Henry and Price, 1985). Probably less is understood about the EdwardsTrinity aquifer in the Trans-Pecos than about any other part of the Edwards-Trinity aquifer system.

The Edwards-Trinity aquifer does not dominate the ground-water-flow system in the Trans-Pecos, as it does in the Edwards Plateau. On average, the EdwardsTrinity aquifer is less permeable than the contiguous, hydraulically connected Cenozoic Pecos alluvium aquifer (fig. 2). The average hydraulic conductivity of the Edwards-Trinity aquifer probably is no greater than the most permeable part of the underlying Dockum aquifer. Therefore, the combined influence of all the interconnected permeable rocks must be considered when conceptualizing the regional flow system of the Trans-Pecos.

The hydraulic conditions of the Washita and Fredericksburg rocks in the Trans-Pecos largely are unpredictable because the available hydrogeologic data are sparse and inconclusive. Most of the Washita strata and much of the Fredericksburg strata in Pecos and Terrell Counties are unreliable sources of ground water because they are relatively impermeable, or they lie above the saturated part of the regional flow system. The hydraulic characteristics of the Washita and Fredericksburg strata in Reeves County have not been differentiated from that of the underlying Trinity rocks (Ogilbee and others, 1962). Where the Washita and Fredericksburg strata are saturated in eastern Pecos County and in Terrell County, they provide small quantities of water to stock wells. Southwest of Fort Stockton (west-central Pecos County), limestone of the Finlay Formation contains a fault-controlled network of interconnected solution channels that has yielded up to 2,500 $\mathrm{gal} / \mathrm{min}$ to irrigation wells (Armstrong and McMillion, 1961, p. 59). In areas where solution chan- nels have not developed, the equivalent strata yield considerably less water ( 100 to $500 \mathrm{gal} / \mathrm{min}$ ) to individual wells. The discharge of many wells and springs in southwestern Pecos County has decreased over the years because ground-water withdrawals have lowered water levels below the solution channels that comprise the zones of greatest hydraulic conductivity.

Permeable Trinity strata in the Trans-Pecos include the basal Cretaceous sand, and in southern parts of Pecos and Terrell Counties, the Glen Rose Limestone and Maxon Sand (fig. 6). The Trinity Group generally is less than $500 \mathrm{ft}$ thick in the Trans-Pecos, where much of it is unsaturated or marginally permeable. The availability of ground water from the Trinity Group generally is untested in Terrell County, and the Maxon Sand and upper few hundred feet of Glen Rose Limestone generally are not saturated in Brewster County. Neither the Glen Rose Limestone nor the Maxon Sand is present in Reeves County, and the hydrologic aspects of the basal Cretaceous sand have not been distinguished from that of other Cretaceous strata in this area (Ogilbee and others, 1962, p. 27). Although the basal Cretaceous sand is only about 150 $\mathrm{ft}$ thick near Fort Stockton (fig. 9), this coarse-grained, quartzose unit is an important source of ground water in Pecos County (Armstrong and McMillion, 1961, p. 57,62). The basal Cretaceous sand has yielded up to $500 \mathrm{gal} / \mathrm{min}$ of water to individual industrial, irrigation, and public-supply wells in Pecos County.

The Edwards-Trinity aquifer is connected hydraulically to the Cenozoic Pecos alluvium, which fills two structural troughs in parts of Crane, Loving, Pecos, Reeves, Ward, and Winkler Counties. Much of the Edwards-Trinity strata was displaced and later eroded from the area now occupied by the alluvium, as a result of the dissolution and collapse of underlying Permian rocks (Maley and Huffington, 1953). The alluvium is predominately an unconsolidated to semiconsolidated mixture of gravel, sand, silt, clay, and caliche. Although the alluvium is highly permeable in most areas, the hydraulic conductivity varies greatly because of differences in the degree of sorting and cementation. Where the alluvium is strongly cemented with hardpan (a calcareous precipitate), ground water frequently is perched above the regional potentiometric surface. Where the alluvium is saturated and permeable, it composes the Cenozoic Pecos alluvium aquifer (Ashworth, 1990, p. 12). This aquifer (fig. 2) is the primary source of ground water for irrigation in 
northern Reeves County and in northwestern Pecos County.

The Cenozoic Pecos alluvium rests on Permian and Triassic red beds in northern Reeves County, where the alluvium is greater than $1,500 \mathrm{ft}$ thick in places (Barker and Ardis, in press, pl. 2). Thinner deposits cover the north-facing flank of the southernmost trough, whose floor is composed of Cretaceous strata of the Edwards-Trinity aquifer (Ashworth, 1990, figs. 3, 5). Because the Cenozoic Pecos alluvium is connected hydraulically to the Edwards-Trinity aquifer, the base of the alluvium is considered the base of the regional ground-water-flow system where the Edwards-Trinity rocks are absent (Barker and Ardis, 1992).

The Edwards-Trinity aquifer overlies the Dockum Group of Triassic age in parts of Pecos and Reeves Counties (Barker and Ardis, in press, pl. 2). The upper part of the Dockum Group is absent in some areas, causing sand of the Dockum aquifer (middle part of the Dockum Group) to merge with the basal Cretaceous sand of the Edwards-Trinity aquifer (fig. 2). In these areas, the depth of regional ground-water flow may increase a few hundred feet below the base of the Edwards-Trinity aquifer system (Barker and Ardis, 1992). The Dockum aquifer has been the main source of public-supply water in northeastern Reeves County, where it also provides some water for livestock.

Although the Dockum aquifer directly underlies the Edwards-Trinity aquifer in western Crockett and northeastern Reeves Counties, the extent and importance of the Dockum aquifer is uncertain across Pecos County (fig. 2). The Edwards-Trinity aquifer is directly underlain in this area by Permian and Triassic red beds that have not been differentiated (Barker and Ardis, in press, pls. 2, 5). The uppermost Permian rock unit is a red siltstone cemented with gypsum and calcite that resembles the lower part of the overlying Dockum Group. The lower part of the Dockum Group is composed largely of reworked Upper Permian red-bed strata. The undifferentiated red beds in Pecos County range from 0 to about $1,500 \mathrm{ft}$ thick; however, no part of the interval appears to be a particularly viable source of potable ground water. According to Armstrong and McMillion (1961, p. 37), the red beds of Permian and Triassic age yield "*** small amounts of water at various locations." If the middle Dockum unit is present in Pecos County, it may be thinner and less permeable than the Dockum aquifer of adjacent counties.

The Trans-Pecos aquifers primarily are recharged through the infiltration of storm runoff resulting from precipitation on the northern flanks of the Glass, Barilla, and Davis Mountains, and on the eastern flanks of the Apache and Delaware Mountains (fig. 3). The headwaters of the streams that drain these mountains mostly are confined to narrow channels with nearly impervious streambeds. The high-gradient headwater channels empty into comparatively lowgradient arroyos atop alluvial fans at the base of the mountains. During prolonged storms, runoff discharges from the mountain channels into the porous arroyos, which then recharge the Edwards-Trinity and Cenozoic Pecos alluvium aquifers.

Considerable recharge occurs in south-central Pecos County where the arroyos traverse the alluvial aprons that overlie cavernous limestone of the Edwards-Trinity aquifer. Sinkholes in the limestone greatly expedite the recharge process (Armstrong and McMillion, 1961, p. 46; pl. 14). Some recharge may occur as lateral subsurface inflow from strata deep within the mountains in northern Brewster and Jeff Davis Counties. However, such inflow would have to penetrate rocks that are faulted, folded, and tilted to the extent that flow would be impeded, if not blocked entirely (Rees and Buckner, 1980, fig. 3). Much of the springflow in the Balmorhea area of Reeves County (fig. 3) that follows prolonged periods of heavy precipitation has been traced to the infiltration of precipitation and storm runoff in a narrow anticlinal valley along the eastern escarpment of the Davis Mountains (White and others, 1941, p. 112). The results of more recent geochemical analyses by LaFave and Sharp (1987) indicate that a substantial part of the sustained (longterm) recharge to these springs may originate from relatively remote locations in and near the Apache Mountains.

Recharge has been induced in parts of the TransPecos as the result of water-level decline caused by the withdrawal of irrigation water. In response to waterlevel decline in the Cenozoic Pecos alluvium aquifer, hydraulic gradients between the Pecos River and the aquifer have reversed from their predevelopment condition in parts of Pecos (Armstrong and McMillion, 1961, p. 52) and Reeves Counties (Ogilbee and others, 1962, p. 33). The Pecos River now loses streamflow to the aquifer in parts of northwestern Pecos and northcentral Reeves Counties where the aquifer originally discharged to the river. Leakage from the Pecos River is not necessarily beneficial to the aquifer, as the concentrations of chloride and dissolved solids in the 
Pecos River can exceed 5,000 and 15,000 mg/L, respectively (Grozier and others, 1966).

Although, water levels declined more than $200 \mathrm{ft}$ in parts of Reeves County and more than $100 \mathrm{ft}$ in parts of Pecos County, decreasing rates of ground-water withdrawal since the mid-1960's have allowed water levels to recover as much as $75 \mathrm{ft}$ in some wells (Bush and others, 1993). Reductions in irrigation pumpage have occurred in response to (1) prolonged periods of greater-than-normal precipitation since the mid1970 's; (2) fuel and labor costs that began to escalate during the 1970's; and (3) depressed profits in the agricultural marketplace during the last 20 years or so. An undetermined fraction of the irrigation water in shallow water-table areas percolates back to the saturated zone, thereby reducing the effect of ground-water withdrawal in some low-lying areas of the Trans-Pecos. Despite this return flow and the decreasing rates of withdrawal, water-level hydrographs indicate that water levels have not returned to predevelopment levels in Pecos County (T.A. Small, U.S. Geological Survey, written commun., 1990). Nor have water levels recovered fully in Reeves County (Sharp, 1989, p. 129).

Whereas well withdrawals in the Trans-Pecos were negligible through about 1945 , withdrawal rates accelerated along with agricultural expansion following World War II. The number of irrigation wells increased annually by almost 25 percent between 1946 and the late 1950's. Irrigation pumpage from the Edwards-Trinity and Cenozoic Pecos alluvium aquifers in Pecos and Reeves Counties increased to about 550,000 acre-ft/yr by the late 1950's (Armstrong and McMillion, 1961, p. 44; Ogilbee and others, 1962, p. 34). However, withdrawals from the Edwards-Trinity aquifer decreased to about 450,000 acre-ft/yr during the mid-1970's (Lurry and Pavlicek, 1991). During this time, less than 1,250 acre-ft/yr of ground water was pumped in Terrell County, where about 1,000 acre-ft/yr was used for livestock and irrigation (Lurry and Pavlicek, 1991).

Springflow from the Trans-Pecos aquifers has decreased substantially as the result of water-level declines caused by ground-water withdrawals for irrigation. Although the combined springflow in Pecos and Reeves Counties averaged nearly 85,000 acre-ft/yr during the mid-1940's (Armstrong and McMillion, 1961, p. 43-44; Ogilbee and others, 1962, p. 28), springflow averaged less than 40,000 acre-ft/yr during the 1980's. Before 1946, about 48,000 acre-ft/yr of water discharged from springs in Pecos County; by 1958, this discharge had decreased to less than 2,000 acre-ft/yr (Armstrong and McMillion, 1961, p. 47). Despite short-term surges in springflow during 1986-88 (Small and Ozuna, 1993, fig. 13), springflow in Pecos County was negligible during 1961-90.

The development of ground water in the TransPecos probably has reduced the loss of ground water to evapotranspiration. Ground-water losses through phreatophytes are locally important in the Pecos River valley, where the tap roots of salt cedar, mesquite, and alfalfa may exceed $50 \mathrm{ft}$ in length.

The largest transmissivity values in the TransPecos are recorded for the Cenozoic Pecos alluvium aquifer, where transmissivity probably averages about $5,000 \mathrm{ft}^{2} / \mathrm{d}$. Transmissivity values reported for thicker parts of the Cenozoic Pecos alluvium aquifer in northcentral Reeves County are as large as $20,000 \mathrm{ft}^{2} / \mathrm{d}$ (Ogilbee and others, 1962, p. 37). Transmissivity values for the Washita, Fredericksburg, and Trinity strata are variable and difficult to obtain. A few transmissivity values derived from the results of aquifer tests (Theis, 1935) are reported for Pecos and Reeves Counties by Armstrong and McMillion (1961) and Ogilbee and others (1962), respectively. Although the transmissivity of Fredericksburg strata that contain a large number of solution channels in west-central Pecos County is unknown, the results of aquifer tests in areas of relatively unaltered limestone generally indicate transmissivity values of less than $1,000 \mathrm{ft}^{2} / \mathrm{d}$. The analyses of drawdown and recovery data from wells completed in the basal Cretaceous sand provide transmissivity values ranging from about 500 to $1,000 \mathrm{ft}^{2} / \mathrm{d}$.

\section{SUMMARY}

The Edwards-Trinity aquifer system, which underlies about $42,000 \mathrm{mi}^{2}$ of west-central Texas, is composed of nearly flat-lying carbonate strata of mostly Comanchean (Lower Cretaceous) age. The Cretaceous rocks of the aquifer system thin toward the northwest atop massive, comparatively impermeable and structurally complex pre-Cretaceous rocks. From predominately terrigenous clastic sediments in the east and fluvial-deltaic (terrestrial) deposits in the west, the rocks of early Trinitian age grade upward into supratidal evaporitic and dolomitic strata, intertidal limestone and dolostone, and shallow-marine, openshelf, and reefal strata of late Trinitian, Fredericksburgian, and Washitan age. A thick, downfaulted remnant of mostly open-marine strata of Eaglefordian through 
Navarroan age composes a small, southeastern part of the aquifer system.

The regional aquifer system is divided into three aquifers and two confining units. The aquifers are the Edwards aquifer in the Balcones fault zone, the Trinity aquifer in the Balcones fault zone and Hill Country, and the Edwards-Trinity aquifer in the Edwards Plateau and Trans-Pecos. These aquifers are laterally adjacent except in the Balcones fault zone, where the rocks are downfaulted and the Trinity aquifer is overlain by the Edwards aquifer. The two confining units are the Navarro-Del Rio confining unit, which overlies the subcrop of the Edwards aquifer, and the Hammett confining unit, which lies within the updip, basal part of the Trinity aquifer and a small southeastern fringe of the Edwards-Trinity aquifer.

The depositional, tectonic, and diagenetic characteristics of the Cretaceous rocks of the EdwardsTrinity aquifer system are strikingly different from those of the underlying pre-Cretaceous rocks. The relatively thin, nearly flat-lying Cretaceous strata of the aquifer system typically dip southeastward atop much thicker Paleozoic and Triassic units that generally dip westward. The unconformity between the Cretaceous rocks of the aquifer system and the pre-Cretaceous complex marks a major change in the geologic history of the study area. This hiatus spans a transition from the deposition of terrestrial red beds during Late Triassic time to the deposition of terrigenous clastic and shallow-marine carbonate sediments during Early Cretaceous time, transcending about 60 million years of crustal warping and erosion during the Jurassic Period.

The Early Cretaceous sea encroached slowly westward upon a peneplained surface of folded and faulted pre-Cretaceous rocks. Trinity deposition was characterized by a cyclic pattern of shoreline advances and retreats, superimposed upon an overall pattern of transgression. While terrestrial deposition prevailed on alluvial plains landward of the advancing shoreline, terrigenous and restricted shallow-marine environments dominated the gently inclined, upper part of a continental shelf over which warm, generally clear seawater circulated. The resulting lithofacies are diachronous toward the Llano uplift, reflecting the effects of shallower water and shoreline advancement toward the northwest. The Trinity Group of west-central Texas was deposited during three transgressive-regressive cycles of sedimentation. These deposits include: (1) the Sycamore Sand (Hosston Formation, downdip) and Sligo Formation; (2) the Hammett Shale (Pine
Island Shale Member, downdip) and Cow Creek Limestone (Cow Creek Limestone Member, downdip); and (3) the Hensel Sand (Bexar Shale Member, downdip) and Glen Rose Limestone. The basal Cretaceous sand and Maxon Sand amassed in fluvial-deltaic settings west of the Llano uplift.

The Fredericksburg Group and most of the Washita Group of west-central Texas were deposited leeward of the Stuart City reef trend upon a broad expanse of sea floor called the Comanche shelf. The Kainer and Person Formations formed over the San Marcos arch, a comparatively narrow structural high dominated by tidal flats and shallow water deposits that frequently underwent uplift, subaerial exposure, and erosion. The eastern part of the Fort Terrett Formation and the Segovia Formation formed near the crest of the central Texas platform in mostly supratidal to restricted shallow-marine environments. The western part of the Fort Terrett Formation and the Fort Lancaster Formation formed in mostly open shallow-marine to openshelf environments transitional to the central Texas platform and Fort Stockton basin. The Finlay Formation was deposited early in the Fort Stockton basin when it was mostly a shallow, open lagoon; the Boracho Formation was deposited later in a deeper, shelfbasin environment. The West Nueces, McKnight, and Salmon Peak Formations formed within a persistently submerged Maverick basin. Environments inside the Maverick basin generally were isolated from northern environments by the Devils River reef trend, in which the Devils River Formation formed.

During late Oligocene through early Miocene time, large-scale normal faulting created the Balcones fault zone, within which the Cretaceous strata were downfaulted, intensively fractured, and differentially rotated within a series of northeast-trending fault blocks. Ground-water flow shifted toward the northeast in response to high-angle barrier faults that impeded or completely blocked southeastward flow. Flowpaths became increasingly ingrained toward the northeast as evaporites and unstable carbonate constituents dissolved from the fractured terrain and discharged in that direction through springs and deeply entrenched streams.

Springs originated in topographically low areas, where barrier faults intercepted confined water at depth and diverted it to the surface. A rejuvenated stream network breached the overburden of low-permeability Gulf rocks, providing discharge areas for developing 
aquifers in the underlying, relatively permeable Comanche rocks.

The aquifers developed as flowpaths converged toward spring outlets, and the rocks became more permeable through dissolution. Solution channels spread outward from the springs. Zones of honeycombed and cavernous porosity evolved into major conduits of ground-water flow. The major springs persisted and control modern potentiometric levels and discharge patterns.

Erosion eventually removed most of the Fredericksburg and Washita strata between the Balcones fault zone and the Edwards Plateau, exposing Trinity strata in the extensively dissected Hill Country. The aquifers in the Hill Country, Edwards Plateau, and Trans-Pecos generally were excluded from the vertical displacement, intensive fracturing, and subsequent dissolution responsible for the hydraulic characteristics of the Edwards aquifer.

In addition to fracturing the rocks of the Balcones fault zone and extending the depth of freshwater diagenesis, the Balcones faulting vertically displaced the terrain, which steepened hydraulic gradients and maintained relatively large flow velocities near the surface. A shallow, dynamic flow system evolved, which promoted dissolution and enhanced the transmissivity of the Edwards aquifer. Cementation, recrystallization, and mineral replacement - caused by deeper, comparatively sluggish ground-water circulation-combined to diminish the transmissivity of the Trinity and EdwardsTrinity aquifers. Although transmissivity values in the Edwards aquifer average about $750,000 \mathrm{ft}^{2} / \mathrm{d}$, transmissivity values elsewhere average less than $10,000 \mathrm{ft}^{2} / \mathrm{d}$.

The Edwards aquifer in the Balcones fault zone is one of the most productive reservoirs of potable ground water in the Nation. The Edwards aquifer is the primary source of water in the San Antonio area, where it serves the domestic, public-supply, industrial, and agricultural needs of more than 1 million people. The Edwards aquifer comprises the Edwards Group and the Georgetown Formation in the northeastern part of the Balcones fault zone and the Devils River, West Nueces, McKnight, and Salmon Peak Formations in the southwestern part of the Balcones fault zone. Ground-water flow largely is controlled by an anisotropic pattern of hydraulic conductivity. The largest values of transmissivity are aligned with the network of en echelon faults that bend around the southeastern flank of the Llano uplift; the principal flow direction is northeastward. Transmissivity values range from about 200,000 to about $2,000,000 \mathrm{ft}^{2} / \mathrm{d}$. Well withdrawals have steadily increased, averaging about 470,000 acre-ft/yr during the 1980's.

The Trinity aquifer, composed of the Trinity Group in the Balcones fault zone and Hill Country, dominates the ground-water hydrology of the Hill Country, where most of the Fredericksburg and practically all of the Washita strata are absent. Strongly cemented, hydraulically tight sediments within upper and middle parts of the Glen Rose Formation generally impede the downward percolation of precipitation, which results in shallow flowpaths above the regional flow system. Ground water is commonly perched in interstream areas above the base level of adjacent streams. Thus, much of the shallow ground water in interstream segments of the Hill Country is discharged to perennial streams that drain the area instead of percolating to the regional flow system. Streamflow gains in the Hill Country typically are lost to the downstream recharge area of the Edwards aquifer in the Balcones fault zone where the streams cross major faults and flow onto the relatively permeable outcrop of the Edwards Group. Ground-water pumpage in the Hill Country totaled between 10,000 and 15,000 acre-ft/yr during the mid-1970's. Transmissivity values range from less than 1,000 to about $50,000 \mathrm{ft}^{2} / \mathrm{d}$ and average about $5,000 \mathrm{ft}^{2} / \mathrm{d}$.

The Edwards-Trinity aquifer in the Edwards Plateau comprises all Cretaceous sediments below the Del Rio Clay, or Buda Limestone where the Del Rio Clay is absent. Washita and Fredericksburg rocks are the principal water-producing zones in southern parts of the area, except where they are breached by erosion along the valleys of the Concho, Guadalupe, Llano, Pecos, Pedernales, and San Saba Rivers. In these topographically low areas, middle and lower Trinity units augment the valley alluvium as the main sources of ground water. The basal Cretaceous sand is the principal aquifer in northwestern parts of the area and along parts of the Pecos River valley. Hydraulic conditions in the Edwards Plateau mostly are confined or semiconfined, except in the shallowest water-transmitting zones and near the fringes of Fredericksburg strata where sandy Trinity sediments crop out. About 80 percent of the roughly 130,000 acre- $f t$ of annual pumpage was used for irrigation during the mid-1970's. Water-level hydrographs reflect a cyclic relation between recharge from precipitation and water-level change: (1) declining water levels during most of the 1960's, when precipitation was below normal; (2) rising water levels 
during most of the 1970's, when precipitation was above normal; and (3) declining water levels during most of the 1980's, when precipitation was below normal. Although transmissivity values probably average less than $5,000 \mathrm{ft}^{2} / \mathrm{d}$ over most of the Edwards Plateau, they may approach $10,000 \mathrm{ft}^{2} / \mathrm{d}$ in southern parts of the area, where the Cretaceous sediments are thickest.

The Edwards-Trinity aquifer in the Trans-Pecos comprises all Cretaceous sediments below the Del Rio Clay, or Buda Limestone where the Del Rio Clay is absent. Water from the Edwards-Trinity aquifer is supplemented by water from the Cenozoic Pecos alluvium aquifer and the Dockum aquifer. Because of accelerating rates of ground-water withdrawal associated with agricultural expansion following World War II, water levels declined and springflow decreased sharply. After irrigation pumpage in Pecos and Reeves Counties had increased to about 550,000 acre-ft/yr by the late 1950's, total pumpage decreased to about 450,000 acre-ft/yr during the mid-1970's. Only about 1,250 acre-ft/yr of ground water was pumped in Terrell County during the mid-1970's. Springflow decreased from an average of nearly 85,000 acre-ft/yr during the mid-1940's to less than 40,000 acre-ft/yr during the 1980's. Transmissivity values in the Edwards-Trinity aquifer generally are less than $1,000 \mathrm{ft}^{2} / \mathrm{d}$. The largest transmissivity values are in the Cenozoic Pecos alluvium aquifer, where values average about $5,000 \mathrm{ft}^{2} / \mathrm{d}$ and are as large as 20,000 $\mathrm{ft}^{2} / \mathrm{d}$ in the thicker parts of the aquifer in north-central Reeves County.

\section{REFERENCES CITED}

Abbott, P.L., 1975, On the hydrology of the Edwards Limestone, south-central Texas: Journal of Hydrology, v. 24, p. 251-269.

1977, Effect of Balcones faults on groundwater movement, south central Texas: Texas Journal of Science, v. 29, no. 1 and 2, p. 5-14.

Adkins, W.S., 1933, The Mesozoic Systems in Texas, in The geology of Texas, v. I, stratigraphy: Austin, University of Texas, Bureau of Economic Geology Bulletin 3232, p. 239-518.

Amsbury, D.L., 1974, Stratigraphic petrology of Lower and Middle Trinity rocks on the San Marcos platform, south-central Texas, in Perkins, B.F., ed., Aspects of Trinity division geology-a symposium: Louisiana State University, Geoscience and man, v. 8, p. 1-35.

Ardis, A.F., and Barker, R.A., 1993, Historical saturated thickness of the Edwards-Trinity aquifer system and selected contiguous hydraulically connected units, west-central Texas: U.S. Geological Survey WaterResources Investigations Report 92-4125, 2 sheets.

Armstrong, C.A., and McMillion, L.G., 1961, Geology and ground-water resources of Pecos County, Texas: Texas Board of Water Engineers Bulletin 6106, v. I, 241 p.

Arnow, Ted, 1963, Ground-water geology of Bexar County, Texas: U.S. Geological Survey Water-Supply Paper $1588,36 \mathrm{p}$.

Ashworth, J.B., 1983, Ground-water availability of the Lower Cretaceous formations in the Hill Country of south-central Texas: Texas Department of Water Resources Report 273, 173 p.

1990, Evaluation of ground-water resources in parts of Loving, Pecos, Reeves, Ward, and Winkler Counties, Texas: Texas Water Development Board Report 317, $51 \mathrm{p}$.

Ashworth, J.B., and Christian, P.C., 1989, Evaluation of ground-water resources in parts of Midland, Reagan, and Upton Counties, Texas: Texas Department of Water Resources Report 312, 52 p.

Ashworth, J.B., and Flores, R.R., 1991, Delineation criteria for the major and minor aquifer maps of Texas: Texas Water Development Board Report LP-212, 51 p.

Baker, E.T., Jr., Slade, R.M., Jr., Dorsey, M.E., Ruiz, L.M., and Duffin, G.L., 1986, Geohydrology of the Edwards aquifer in the Austin area, Texas: Texas Water Development Board Report 293, 217 p.

Barker, R.A., and Ardis, A.F., 1992, Configuration of the base of the Edwards-Trinity aquifer system and hydrogeology of the underlying pre-Cretaceous rocks, westcentral Texas: U.S. Geological Survey WaterResources Investigations Report 91-4071, 25 p. in press, Hydrogeologic framework of the EdwardsTrinity Aquifer System, west-central Texas: U.S. Geological Survey Professional Paper 1421-B.

Bathurst, R.G.C., 1975, Carbonate sediments and their diagenesis: Amsterdam, Elsevier, 658 p.

Bay, T.A., Jr., 1977, Lower Cretaceous models from Texas and Mexico, in Bebout, D.G., and Loucks, R.G., eds., Cretaceous carbonates of Texas and Mexico, applications to subsurface exploration: Austin, University of Texas, Bureau of Economic Geology Report of Investigations 89, p. 12-30.

Bebout, D.G., 1977, Sligo and Hosston depositional patterns, subsurface of south Texas, in Bebout, D.G., and Loucks, R.G., eds., Cretaceous carbonates of Texas and Mexico, applications to subsurface exploration: Austin, University of Texas, Bureau of Economic Geology Report of Investigations 89, p. 79-96.

Bebout, D.G., Budd, D.A., and Schatzinger, R.A., 1981, Depositional and diagenetic history of the Sligo and Hosston Formations (Lower Cretaceous) in south Texas: Austin, University of Texas, Bureau of Economic Geology Report of Investigations 109, 70 p. 
Texas: Austin, University of Texas, Bureau of Economic Geology Report of Investigations 109, 70 p.

Bebout, D.G., and Loucks, R.G., 1974, Stuart City trend, Lower Cretaceous, South Texas-A carbonate shelf-margin model for hydrocarbon exploration: Austin, University of Texas, Bureau of Economic Geology Report of Investigations 78, 80 p.

Brand, J.P., and Deford, R.K., 1958, Comanchean stratigraphy of Kent quadrangle, Trans-Pecos Texas: American Association of Petroleum Geologists Bulletin, v. 42, no. 2, p. 371-386.

Brune, Gunnar, and Duffin, G.L., 1983, Occurrence, availability, and quality of ground water in Travis County, Texas: Texas Department of Water Resources Report 276, $219 \mathrm{p}$.

Bush, P.W., Wynn, K.H., and Ardis, A.F., 1993, Historical potentiometric surface of the Edwards-Trinity aquifer system and contiguous hydraulically connected units, west-central Texas: U.S. Geological Survey WaterResources Investigations Report 92-4055, 3 sheets.

Butterworth, R.A., 1970, Sedimentology of the Maxon Formation (Cretaceous), west Texas: Austin, University of Texas unpub. M.A. thesis, $132 \mathrm{p}$.

Carr, J.T., Jr., 1967, The climate and physiography of Texas: Texas Water Development Board Report 53, 27 p.

Carr, M.M., 1987, Facies and depositional environments of the Lower Cretaceous McKnight Formation evaporites, Maverick basin, southwest Texas: Arlington, University of Texas unpub. M.S. thesis, 144 p.

Choquette, P.W., and Pray, L.C., 1970, Geologic nomenclature and classification of porosity in sedimentary carbonates: American Association of Petroleum Geologists Bulletin, v. 54, no. 2, p. 207-250.

DeCook, K.J., 1963, Geology and ground-water resources of Hays County, Texas: U.S. Geological Survey WaterSupply Paper 1612, 72 p.

Duffin, G.L., 1974, Subsurface saline water resources in the San Antonio area, Texas: Texas Water Development Board Open-File Report, 39 p.

Ellis, Patricia, 1986, Post-Miocene carbonate diagenesis of the Lower Cretaceous Edwards Group in the Balcones fault zone area, south-central Texas, in Abbott, P.L., and Woodruff, C.M., eds., The Balcones escarpment, central Texas: Geological Society of America, p. 101-114.

Ewing, T.E., 1991, The tectonic framework of Texas, with accompanying tectonic map of Texas: Austin, University of Texas, Bureau of Economic Geology, $36 \mathrm{p}$.

Fenneman, N.M., 1931, Physiography of western United States: New York, McGraw-Hill, 534 p.

Fisher, W.L., and Rodda, P.U., 1966, Nomenclature revision of basal Cretaceous rocks between the Colorado and Red Rivers, Texas: Austin, University of Texas, Bureau of Economic Geology Report of Investigations 58, p. 120.
Flawn, P.T., 1956, Basement rocks of Texas and southeast New Mexico: Austin, University of Texas, Bureau of Economic Geology Publication 5605, 261 p.

1964, Basement rocks of the Texas Gulf Coastal Plain: Transactions of the Gulf Coast Association of Geological Societies, v. 14, p. 271-275.

Flawn, P.T., Goldstein, August, Jr., King, P.B., and Weaver, C.E., 1961, The Ouachita system: Austin, University of Texas, Bureau of Economic Geology Publication 6120, $401 \mathrm{p}$.

Forgotson, J. M., Jr., 1956, A correlation and regional stratigraphic analysis of the formations of the Trinity Group of the Comanchean Cretaceous of the Gulf Coastal Plain; and the genesis and petrology of the Ferry Creek Anhydrite: Transactions of the Gulf Coast Association of Geological Societies, v. 6, p. 91-108.

1957, Stratigraphy of Comanchean Cretaceous Trinity Group: American Association of Petroleum Geologists Bulletin, v. 41, no. 10, p. 2,328-2,363.

Grozier, U.R., Albert, H.W., Blakey, J.F., and Hembree, C.H., 1966, Water-delivery and low-flow studies, Pecos River, Texas, quantity and quality, 1964 and 1965: Texas Water Development Board Report 22, 21 p.

Gutentag, E.D., Heimes, F.J., Krothe, N.C., Luckey, R.R., and Weeks, J.B., 1984, Geohydrology of the High Plains aquifer in parts of Colorado, Kansas, Nebraska, New Mexico, Oklahoma, South Dakota, Texas, and Wyoming: U.S. Geological Survey Professional Paper 1400-B, 63 p.

Halley, R.B., and Rose, P.R., 1977, Significance of freshwater limestones in marine carbonate successions of Pleistocene and Cretaceous age, in Bebout, D.G., and Loucks, R.G., eds., Cretaceous carbonates of Texas and Mexico, applications to subsurface exploration: Austin, University of Texas, Bureau of Economic Geology Report of Investigations 89, p. 206-215.

Hammond, W.W., Jr., 1984, Hydrogeology of the Lower Glen Rose aquifer, south-central Texas: Austin, University of Texas, unpub. Ph.D. dissertation, $245 \mathrm{p}$.

Hill, R.T., 1901, Geography and geology of the Black and Grand Prairies, Texas, with detailed descriptions of the Cretaceous formations and special reference to artesian water: U.S. Geological Survey, 21st Annual Report, pt. $7,666 \mathrm{p}$.

Hill, R.T., and Vaughan, T.W., 1898, Geology of the Edwards Plateau and Rio Grande plain adjacent to Austin and San Antonio, Texas, with reference to the occurrence of underground waters: U.S. Geological Survey, 18th Annual Report, pt. 2, p. 193-321.

Henry, C.D., and Price, J.G., 1985, Summary of the tectonic development of Trans-Pecos, Texas: Austin, University of Texas, Bureau of Economic Geology Miscellaneous Map no. 36, 8 p. 
Howard, W.V., and David, M.W., 1936, Development of porosity in limestones: American Association of Petroleum Geologists Bulletin, v. 20, no. 11, p. 1,389-1,412.

Humphreys, C.H., 1984, Stratigraphy of the Lower Cretaceous (Albian) Salmon Peak Formation of the Maverick basin, south Texas, in Smith, C.I., ed., Stratigraphy and structure of the Maverick basin and Devils River trend, Lower Cretaceous, southwest Texas-A field guide and related papers: South Texas Geological Society, p. 34-59.

Imlay, R.W., 1945, Subsurface Lower Cretaceous formations of south Texas: American Association of Petroleum Geologists Bulletin, v. 29, p. 1,416-1,469.

Inden, R.F., 1974, Lithofacies and depositional model for a Trinity Cretaceous sequence, central Texas, in Perkins, B.F., ed., Aspects of Trinity division geology-a symposium: Louisiana State University, Geoscience and man, v. 8, p. 37- 52 .

Jager, E.H., 1942, Pre-Cretaceous topography of western Edwards Plateau, Texas: American Association of Petroleum Geologists Bulletin, v. 26, no. 3, p. 380-386.

Jakucs, Laszlo, 1977, Morphogenetics of karst regions: New York, Halsted Press, Wiley and Sons, 284 p.

Kastning, E.H., 1983, Relict caves as evidence of landscape and aquifer evolution in a deeply dissected carbonate terrain-Southwest Edwards Plateau, Texas, U.S.A., in Back, William, and LaMoreaux, P.E., eds., V.T. Stringfield symposium, Processes in karst hydrology: Journal of Hydrology, v. 61, p. 89-112.

King, P.B., 1942, Permian of west Texas and southeastern New Mexico: American Association of Petroleum Geologist Bulletin, v. 26, no. 4, p. 535-763.

1980, Geology of the eastern part of the Marathon Basin, Texas; U.S. Geological Survey Professional Paper 1157, 40 p.

Kuniansky, E.L., 1989, Precipitation, streamflow, and base flow in west-central Texas, December 1974 through March 1977: U.S. Geological Survey Water-Resources Investigations Report 88-4218, 2 sheets.

1990, Potentiometric surface of the Edwards-Trinity aquifer system and contiguous hydraulically connected units, west-central Texas, winter 1974-75: U.S. Geological Survey Water-Resources Investigations Report 89-4208, 2 sheets.

LaFave, J.I., and Sharp, J.M., Jr., 1987, Origins of ground water discharging at the springs of Balmorhea: West Texas Geological Society Bulletin, v. 26, no. 9, p. 5-14.

LeGrand, H.E., and Stringfield, V.T., 1971, Development and distribution of permeability in carbonate aquifers: Water Resources Research, v. 7, no. 5, p. 1,284-1,294.

Linsley, R.K., Jr., Kohler, M.A., and Paulhus, J.L.H., 1975, Hydrology for Engineers: New York, McGraw-Hill, $482 \mathrm{p}$.
Loucks, R.G., 1977, Porosity development and distribution in shoal-water carbonate complexes-subsurface Pearsall Formation (Lower Cretaceous) south Texas, in Bebout, D.G., and Loucks, R.G., eds., Cretaceous carbonates of Texas and Mexico, applications to subsurface exploration: Austin, University of Texas, Bureau of Economic Geology Report of Investigations 89, p. 97-126.

Lozo, F.E., Jr., and Smith, C.I., 1964, Revision of Comanche Cretaceous stratigraphic nomenclature, southern Edwards Plateau, southwest Texas: Transactions of the Gulf Coast Association of Geological Societies, v. 14, p. 285-307.

Lozo, F.E., Jr., and Stricklin, F.L., Jr., 1956, Stratigraphic notes on the outcrop basal Cretaceous, central Texas: Transactions of the Gulf Coast Association of Geological Societies, v. 6, p. 67-78.

Lurry, D.L., and Pavlicek, D.J., 1991, Withdrawals from the Edwards-Trinity aquifer system and contiguous hydraulically connected units, west-central Texas, December 1974 through March 1977: U.S. Geological Survey Water-Resources Investigations Report 914021, 1 sheet.

Maclay, R.W., and Land, L.F., 1988, Simulation of flow in the Edwards aquifer, San Antonio region, Texas, and refinement of storage and flow concepts: U.S. Geological Survey Water-Supply Paper 2336-A, 48 p.

Maclay, R.W., Rettman, P.L., and Small, T.A., 1980, Hydrochemical data for the Edwards aquifer in the San Antonio area, Texas: Texas Department of Water Resources LP-131, 38 p.

Maclay, R.W., and Small, T.A., 1983, Hydrostratigraphic subdivisions and fault barriers of the Edwards aquifer, south-central Texas, U.S.A., in Back, William, and LaMoreaux, P.E., eds., V.T. Stringfield symposium, Processes in karst hydrology: Journal of Hydrology, v. 61, p. 127-146.

1986, Carbonate geology and hydrology of the Edwards aquifer in the San Antonio area, Texas: Texas Water Development Board Report 296, 90 p.

Maley, V.C., and Huffington, R.M., 1953, Cenozoic fill and evaporite solution in the Delaware basin, Texas and New Mexico: Geological Society of America Bulletin, v. 64 , no. 5 , p. $539-546$.

McFarlan, Edward, Jr., 1977, Lower Cretaceous sedimentary facies and sea level changes, U.S. Gulf Coast, in Bebout, D.G., and Loucks, R.G., eds., Cretaceous carbonates of Texas and Mexico, applications to subsurface exploration: Austin, University of Texas, Bureau of Economic Geology Report of Investigations 89, p. 5-11.

McGowen, J.H., Granata, G.E., and Seni, S.J., 1979, Depositional framework of the Lower Dockum Group (Triassic), Texas Panhandle: Austin, University of Texas, 
Bureau of Economic Geology Report of Investigations $97,60 \mathrm{p}$.

Miller, B.C., 1984, Physical stratigraphy and facies analysis, Lower Cretaceous, Maverick basin and Devils River trend, Uvalde and Real Counties, Texas, in Smith, C.I., ed., Stratigraphy and structure of the Maverick basin and Devils River trend, Lower Cretaceous, southwest Texas-A field guide and related papers: South Texas Geological Society, p. 3-33.

Mount, J.R., Rayner, F.A., Shamburger, V.M., Jr., Peckam, R.C., and Osborne, F.L., Jr., 1967, Reconnaissance investigation of the ground-water resources of the Colorado River Basin, Texas: Texas Water Development Board Report 51, 107 p.

Murray, G.E., 1961, Geology of the Atlantic and Gulf Coastal Province of North America: New York, Harper and Brothers, $692 \mathrm{p}$.

Myers, B.N., 1969, Compilation of results of aquifer tests in Texas: Texas Water Development Board Report 98, $537 \mathrm{p}$.

Nalley, G.M., 1989, Compilation of hydrologic data for the Edwards aquifer, San Antonio area, Texas, 1988, with 1934-88 summary: Edwards Underground Water District Bulletin 48, 157 p.

Ogilbee, William, Wesselman, J.B., and Irelan, Burdge, 1962, Geology and ground-water resources of Reeves County, Texas: Texas Water Commission Bulletin 6214, v. 1, 193 p.

Pavlicek, D.J., Small, T.A., and Rettman, P.L., 1987, Hydrogeologic data from a study of the freshwater zone/ salinewater zone interface in the Edwards aquifer, San Antonio region, Texas: U.S. Geological Survey OpenFile Report 87-389, 108 p.

Pearson, F.J., Jr., and Rettman, P.L., 1976, Geochemical and isotopic analyses of waters associated with the Edwards Limestone aquifer, central Texas: Edwards Underground Water District Report, $35 \mathrm{p}$.

Perkins, B.F., 1974, Paleoecology of a rudist reef complex in the Comanche Cretaceous, Glen Rose Limestone, central Texas, in Perkins, B.F., ed., Aspects of Trinity division geology-a symposium: Louisiana State University, Geoscience and man, v. 8, p. 131-173.

Petta, T.J., 1977, Diagenesis and geochemistry of a Glen Rose patch reef, Bandera County, Texas, in Bebout, D.G., and Loucks, R.G., eds., Cretaceous carbonates of Texas and Mexico, applications to subsurface exploration: Austin, University of Texas, Bureau of Economic Geology Report of Investigations 89, p. 138-167.

Reaser, D.F., and Malott, V.E., 1985, Finlay LimestoneA key to geological interpretation in western TransPecos Texas and northeastern Chihuahua, Mexico, in Dickerson, P.W., and Muehlberger, W.R., eds., Structure and tectonics of Trans-Pecos Texas: West Texas
Geological Society Field Conferences, Publication 8581, p. 213-219.

Rees, Rhys, and Buckner, A.W., 1980, Occurrence and quality of ground water in the Edwards-Trinity (Plateau) aquifer in the Trans-Pecos region of Texas: Texas Department of Water Resources Report 255, $41 \mathrm{p}$.

Riggio, R.F., Bomar, G.W., and Larkin, T.J., 1987, Texas drought-Its recent history (1931-1985): Texas Water Commission LP 87-04, 74 p.

Romanak, M.S., 1988, Sedimentology and depositional environment of the basement sand (Lower Cretaceous), west Texas: Arlington, University of Texas unpub. M.S. thesis, 143 p.

Rose, P.R., 1972, Edwards Group, surface and subsurface, central Texas: Austin, University of Texas, Bureau of Economic Geology Report of Investigations 74, 198 p.

Scott, R.W., and Kidson, E.J., 1977, Lower Cretaceous depositional systems, west Texas, in Bebout, D.G., and Loucks, R.G., eds., Cretaceous carbonates of Texas and Mexico, applications to subsurface exploration: Austin, University of Texas, Bureau of Economic Geology Report of Investigations 89, p. 169-181.

Sellards, E.H., 1933, The pre-Paleozoic and Paleozoic Systems in Texas, in The geology of Texas, v. I, stratigraphy: Austin, University of Texas, Bureau of Economic Geology Bulletin 3232, p. 15-238.

1935, Structural geology of Texas east of Pecos River, in The geology of Texas, v. II, structural and economic geology: Austin, University of Texas, Bureau of Economic Geology Bulletin 3401, p. 11-136.

Sharp, J.M., Jr., 1989, Regional ground-water systems in northern Trans-Pecos Texas, in Structure and stratigraphy of Trans-Pecos Texas-field trip guidebook T317, El Paso to Guadalupe Mountains and Big Bend, July 20-29, 1989: Washington, D.C., American Geophysical Union, p. 123-130.

Slade, R.M., Jr., Dorsey, M.E., and Stewart, S.L., 1986, Hydrology and water quality of the Edwards aquifer associated with Barton Springs in the Austin area, Texas: U.S. Geological Survey Water-Resources Investigations Report 86-4036, 117 p.

Small, T.A., 1986, Hydrogeologic sections of the Edwards aquifer and its confining units in the San Antonio area, Texas: U.S. Geological Survey Water-Resources Investigations Report 85-4259, 52 p.

Small, T.A., and Ozuna, G.B., 1993, Ground-water conditions in Pecos County, Texas, 1987: U.S. Geological Survey Water-Resources Investigations Report 92 $4190,63 \mathrm{p}$.

Smith, C.I., 1970, Lower Cretaceous stratigraphy, northern Coahuila, Mexico: Austin, University of Texas, Bureau of Economic Geology Report of Investigations 65, $101 \mathrm{p}$. 
1979, The Devils River trend and Maverick basin sequence, in Rose, P.R., ed., Stratigraphy of the Edwards Group and equivalents, eastern Edwards Plateau, Texas - guidebook for Gulf Coast Association of Geological Societies field trip 1, October 9-10, 1979:

South Texas Geological Society, p. 14-18.

1981, Review of the geologic setting, stratigraphy, and facies distribution of the Lower Cretaceous in northern Mexico, in Smith, C.I., and Brown, J.B., eds., Lower Cretaceous stratigraphy and structure, northern Mexico-field trip guidebook: West Texas Geological Society Publication no. 81-74, p. 1-27.

Smith, C.I., and Brown, J.B., 1983, Introduction to road log Cretaceous stratigraphy, in Kettenbrink, E.C., Jr. ed., Structure and stratigraphy of the Val Verde BasinDevils River uplift, Texas: West Texas Geological Society Publication 83-77, p. 1-47.

Stricklin, F.L., Jr., and Amsbury, D.L., 1974, Depositional environments on a low-relief carbonate shelf, Middle Glen Rose Limestone, central Texas, in Perkins, B.F., ed., Aspects of Trinity division geology-a symposium: Louisiana State University, Geoscience and man, v. 8, p. 53-66.

Stricklin, F.L., Jr., and Smith, C.I., 1973, Environmental reconstruction of a carbonate beach complex, Cow Creek (Lower Cretaceous) Formation of Central Texas: Geological Society of America Bulletin v. 84, no. 4, p. 1,349-1,367.

Stricklin, F.L., Jr., Smith, C.I., and Lozo, F.E., 1971, Stratigraphy of Lower Cretaceous Trinity deposits of central Texas: Austin, University of Texas, Bureau of Economic Geology Report of Investigations 71, 63 p.

Taff, J.A., 1892, Reports on the Cretaceous area north of the Colorado River: Texas Geological Survey, 3d Annual Report (1891), p. 267-379.

Texas Department of Health, 1977, Drinking water standards governing drinking water quality and reporting requirements for public water systems (revised 1990): Austin, Texas, Division of Water Hygiene, $34 \mathrm{p}$.

Texas Water Development Board, 1990, Water for Texas, today and tomorrow: Texas Water Development Board, Document No. GP-5-1, 186 p.

Theis, C.V., 1935, The relation between the lowering of the piezometric surface and rate and duration of discharge of a well using ground-water storage: American Geophysical Union Transactions, v. 16, p. 519-524.

University of Texas, Bureau of Economic Geology, 1974a, Geologic atlas of Texas, Austin sheet: Austin, scale 1:250,000.

1974b, Geologic atlas of Texas, Big Spring sheet: Austin, scale 1:250,000.

1975, Geologic atlas of Texas, San Angelo sheet: Austin, scale 1:250,000. 1976a, Geologic atlas of Texas, Brownwood sheet: Austin, scale 1:250,000.

1976b, Geologic atlas of Texas, Pecos sheet: Austin, scale $1: 250,000$.

1977, Geologic atlas of Texas, Del Rio sheet: Austin, scale $1: 250,000$.

1981 a, Geologic atlas of Texas, Llano sheet: Austin, scale 1:250,000.

1981b, Geologic atlas of Texas, Sonora sheet: Austin, scale 1:250,000.

1983, Geologic atlas of Texas, San Antonio sheet: Austin, scale 1:250,000.

Walker, L.E., 1979, Occurrence, availability, and chemical quality of ground water in the Edwards Plateau Region of Texas: Texas Department of Water Resources Report $235,336 \mathrm{p}$.

Walper, J.L., and Miller, R.E., 1985, Tectonic evolution of Gulf Coast basin: Gulf Coast Society of Economic Paleontologists and Mineralogists Foundation Fourth Annual Research Conference Proceedings, June 1985, p. $25-41$.

Waters, J.A., McFarland, P.W., and Lea, J.W., 1955, Geologic framework of the Gulf Coastal Plain of Texas: American Association of Petroleum Geologists Bulletin, v. 39 , no. 9, p. $1,821-1,850$.

Webster, R.E., 1980, Structural analysis of Devils River uplift-southern Val Verde basin, southwest Texas: American Association of Petroleum Geologists Bulletin, v. 64 , no. 2 , p. 221-241.

Weeks, A.W., 1945, Balcones, Luling, and Mexia fault zones in Texas: American Association of Petroleum Geologists Bulletin, v. 29, no. 12, p. 1,733-1,737.

Weeks, J.B., Gutentag, E.D., Heimes, F.J., and Luckey, R.R., 1988, Summary of the High Plains Aquifer-System Analysis in parts of Colorado, Kansas, Nebraska, New Mexico, Oklahoma, South Dakota, Texas, and Wyoming: U.S. Geological Survey Professional Paper 1400-A, $30 \mathrm{p}$.

Weeks, J.B., and Sun, R.J., 1987, Regional Aquifer-System Analysis Program of the U.S. Geological Surveybibliography, 1978-86: U.S. Geological Survey WaterResources Investigations Report 87-4138, 81 p.

Welder, F.A., and Reeves, R.D., 1964, Geology and groundwater resources of Uvalde County, Texas: U.S. Geological Survey Water-Supply Paper 1584, 50 p. 
Wermund, E.G., and Woodruff, C.M., Jr., 1977, Land resource units for planning in carbonate terranes, in Tolson, J.S., and Doyle, F.L., eds., International Association of Hydrogeologists Memoirs: Huntsville, Alabama, University of Alabama in Huntsville Press, v. 12, p. 339-353.

Wessel, G.R., 1988, Shallow stratigraphy, structure, and saltrelated features, Yates oil field area, Pecos and Crockett Counties, Texas: Golden, Colorado, Colorado School of Mines, unpub. Ph.D. dissertation, $144 \mathrm{p}$.

White, W.N., Gale, H.S., and Nye, S.S., 1941, Geology and ground-water resources of the Balmorhea area, western Texas: U.S. Geological Survey Water-Supply Paper 849-C, p. 83-146.
Wilhelm, O., and Ewing, M., 1972, Geology and history of the Gulf of Mexico: Geological Society of America Bulletin, v. 85, no. 3, p. 575-600.

Winter, J.A., 1962, Fredericksburg and Washita strata (subsurface Lower Cretaceous), southwest Texas, in Contributions to the geology of south Texas: San Antonio, Texas, South Texas Geological Society, p. 81-115.

Wood, M.L., and Walper, J.L., 1974, The evolution of the interior Mesozoic basin and the Gulf of Mexico: Transactions of the Gulf Coast Association Geological Societies, v. 24, p. $31-41$.

Woodruff, C.M., Jr., and Abbott, P.L., 1986, Stream piracy and evolution of the Edwards aquifer along the Balcones escarpment, central Texas, in Abbott, P.L., and Woodruff, C.M., eds., The Balcones escarpment, central Texas: Geological Society of America, p. 77-90. 